\title{
A INFECÇÃO PERIOdONTAL ASSOCIADA AO PARTO PRÉ-TERMO E BAIXO PESO AO NASCER
}

MARIA CHRISTINA BRUNETTI

Tese de Doutorado apresentada à Faculdade de Saúde Pública da Universidade de São Paulo para obtenção do Grau de Doutor.

Área de concentração: Serviços de Saúde Pública

ORIENTADOR: PROF. DR PAULO CAPEL NARVAI 


\section{AGRADECIMENTOS}

Eu gostaria de expressar meus sinceros agradecimentos:

Ao Prof. Dr. Paulo Capel Narvai, pelo seu apoio e interesse constantes em meu desenvolvimento profissional nestes anos de convívio, pelo estímulo e, acima de tudo, por ter acreditado que era possivel a realização deste trabalho.

Ao Prof. Dr. Eduardo de Souza, pela sua paciência infinda em conduzir-me durante todo o desenvolvimento da parte obstétrica deste estudo, pelos seus valiosos ensinamentos, por seu apoio e encorajamento constantes.

À Prof ${ }^{a} r^{a}$ Maria Lucia Marçal Mazza Sundefeld, pela sua inestimável ajuda e valiosos conselhos desde o início do desenvolvimento do projeto e durante toda a execução do trabalho, pelo seu inesgotável interesse e entusiasmo, pelo seu carinho e amizade.

À Prof ${ }^{a} \mathrm{Dr}^{\mathrm{a}}$ Ana Cristina D'Andretta Tanaka, por ter acreditado que este trabalho era possível, recomendando-me ao Prof. Dr. Luiz Kulay Junior, Coordenador do Curso de Pós-Graduação da Universidade Federal de São Paulo-UNIFESP-EPM.

Aos professores e funcionários do Departamento de Prática de Saúde Pública da FSP-USP, pela receptividade e atenção dispensadas, proporcionando-me a satisfação de ter conquistado novos amigos. 
Ao Prof. Dr. Luiz Kulay Junior por ter me dado a chance de desenvolver o meu trabalho no Departamento de Obstetricia da Escola Paulista de MedicinaUniversidade Federal de São Paulo-UNIFESP-EPM.

Ao Departamento de Obstetrícia da Escola Paulista de Medicina - Universidade Federal de São Paulo-UNIFESP-EPM, por me acolher, e às suas secretárias, pela delicadeza com que me receberam.

Aos Hospitais São Paulo, Vereador José Storópoli (Vila Maria) e Ipiranga, pela autorização de acesso à maternidade, e aos registros das pacientes.

Ao Dr. Marcos Tadeu Garcia, Diretor do Serviço de Ginecologia-Obstetrícia e Neonatologia do Hospital Ipiranga por autorizar o desenvolvimento de parte do meu trabalho naquele nosocômio, bem como pelo seu incentivo e confiança.

A todas as enfermeiras, auxiliares de enfermagem, assistentes sociais, funcionárias da cozinha, funcionários de limpeza, estudantes de Medicina e médicos, pela gostosa amizade que se formou durante a nossa convivência.

À Dra. Carla Andrade, pelos importantes ensinamentos na área de Obstetricia.

À Prof ${ }^{\mathrm{a}} \mathrm{Dr}^{\mathrm{a}}$ Manoela Domingues Martins, pelos ricos ensinamentos na área de Patologia. 
À Prof $f^{a}$ Leda Szabo, pela sua inestimável ajuda na leitura dos artigos em inglês, contatos com Dr. Offenbacher e revisão de toda correspondência em inglês.

Ao Prof. Dr. Steven Offenbacher, pela sua importante contribuição perante as dúvidas levantadas durante o desenvolvimento dos procedimentos metodológicos e análise dos dados coletados

À Prof ${ }^{a} \operatorname{Dr}^{\mathrm{a}}$ Luciana Corrêa pela realização da correção ortográfica.

À Sr ${ }^{\mathrm{a}}$ Luizete Pacheco e Silva, pela dedicação na digitação deste trabalho.

Ao meu marido Ricardo, pela sua infinita compreensão pelos meus momentos de ausência, pela sua paciência, pelo seu apoio e estímulo constantes em meu desenvolvimento profissional e pessoal, pela sua amizade e amor.

A todos aqueles, não citados, e em especial à minha mãe Angelina, os quais de alguma forma contribuíram para a execução deste trabalho, compreendendo meus momentos de ausência e compartilhando comigo todos os bons e maus momentos.

A todas as puérperas que participaram deste estudo, pelo interesse e simpatia demonstrados durante a realização das entrevistas e exame clínico periodontal e pela confiança a mim depositada. 


\section{RESUMO}

Brunetti MC. A infecção periodontal associada ao parto pré-termo e baixo peso ao nascer. São Paulo: 2002. [Tese de Doutorado - Faculdade de Saúde Pública da USP].

Objetivo. A prematuridade, responsável por aproximadamente dois terços da morbidade e mortalidade neonatal, e o baixo peso ao nascer têm especial interesse para a saủde pública. Dentre as intercorrências predisponentes à prematuridade, a doença periodontal vem sendo considerada fator de risco para o nascer prematuro de baixo peso. Nesta pesquisa estuda-se a condição periodontal de puérperas como fator de risco ao parto pré-termo de baixo peso. Método. Estudo de caso-controle, abrangendo 174 puérperas ( 103 controles - parto no termo e peso do bebê ao nascer maior ou igual a 2.500 gramas; e 71 casos - parto a pré-termo e peso do bebê ao nascer inferior a 2.500 gramas), assistidas em três hospitais públicos no municipio de São Paulo, de agosto de 2000 a setembro de 2001. A condição periodontal foi avaliada empregando-se o Índice de Extensão e Severidade da Doença Periodontal. Testes de associação ( $x^{2}$ e Fischer) e Análise de Regressão Logistica Binomial foram realizados, adotando-se o nível de significância de $5 \%$. Resultados. Dentre as puérperas do grupo controle, observou-se severidade na doença periodontal de $1,9 \mathrm{~mm}$ em $8 \%$ dos sítios e, dentre as do grupo caso, $2,0 \mathrm{~mm}$ em $12 \%$ dos sítios. Conclusão. Embora haja associação entre doença periodontal e nascer prematuro $\left(x^{2}\right.$ $=6,12 ; \mathrm{p}=0,01337$ ), na Análise de Regressão Logística Binomial apenas as variáveis "número de visitas no pré-natal", "parto prematuro prévio", "número de partos concluídos" constituíram-se em fatores de risco, uma vez que a doença periodontal não se manteve no modelo final.

Descritores: prematuridade, doença periodontal, baixo peso ao nascer, periodontite. 


\section{SUMMARY}

Brunetti MC. A infecção periodontal associada ao parto pré-termo e baixo peso ao nascer. [Periodontal infection associated to preterm birth and low birth weight]. São Paulo (BR); 2002. [Tese de Doutorado - Faculdade de Saúde Pública da USP].

Objective. Preterm birth, responsible for about two-thirds of neonatal morbidity and mortality, and low-birth weight, constitute a major public health problem Among the many clinical factors which predispose to preterm birth and low birth weight, maternal periodontal disease has received considerable attention as a potential risk factor. This research investigates this possible association, considering it relevant to public health measures, with the aims: 1) to describe the periodontal status in a group of term-mothers, delivering infants with birth weight $\geq 2,500$ grams (controls) and preterm mothers, delivering babies with birth weight $<2,500$ grams (cases); 2) to investigate if the periodontal disease is a risk factor for preterm low birth weight. Method. A case-control study involving 174 randomly selected mothers, 103 controls and 71 cases, who delivered their babies in three public hospitals in the city of São Paulo, from August 2000 to September 2001. Matemal periodontal status was assessed by using the Extension and Severity Index of Periodontal Disease. Significance tests were made by $x^{2}$ and Fischer tests. Results. Among mothers in the control group, severity of periodontal disease of $1.9 \mathrm{~mm}$ in $8 \%$ of the sites was observed and in the case group, $2.0 \mathrm{~mm}$ in $12 \%$ of the sites examined. Conclusion. Although there is association between periodontal disease and preterm birth $\left(x^{2}=\right.$ $6.12 ; p=0.01337$ ), in the Binomial Logistic Regression Analysis, only the variables 
"prenatal care", "previous preterm births", "number of term births" were risk factors, since periodontal disease was absent from the final model.

Descriptors: periodontal disease, low birth weight, periodontitis, prematurity. 


\section{LISTA DE TABELAS}

Tabela 1 - Número e porcentagem de puérperas segundo a idade gestacional e peso do bebê ao nascer. Hospitais: São Paulo, Vila Maria e Ipiranga, agosto/2000 a setembro/2001 66

Tabela 2 - Número e porcentagem de puérperas segundo a idade materna. Hospitais: São Paulo, Vila Maria e Ipiranga, agosto/2000 a setembro/2001

Tabela 3 - Número e porcentagem de puérperas segundo a situação conjugal. Hospitais:

São Paulo, Vila Maria e Ipiranga, agosto/2000 a setembro/2001 67

Tabela 4 - Número e porcentagem de puérperas segundo a realização de pré-natal. Hospitais: São Paulo, Vila Maria e Ipiranga, agosto/2000 a setembro/2001 68

Tabela 5 - Número e porcentagem de puérperas segundo o trimestre de início dos cuidados pré-natais. Hospitais: São Paulo, Vila Maria e Ipiranga, agosto/2000 a setembro/2001 68

Tabela 6 - Número e porcentagem de puérperas segundo o número de consultas no pré-natal. Hospitais: São Paulo, Vila Maria e Ipiranga, agosto/2000 a setembro/2001 69

Tabela 7 - Número e porcentagem de puérperas segundo o local de realização do pré-natal. Hospitais: São Paulo, Vila Maria e Ipiranga, agosto/2000 a setembro/2001. 70

Tabela 8 - Número e porcentagem de puérperas segundo o IMC pré-gravídico. Hospitais: São Paulo, Vila Maria e Ipiranga, agosto/2000 a setembro/2001

Tabela 9 - Número e porcentagem de puérperas segundo o tipo de parturição atual. Hospitais: São Paulo, Vila Maria e Ipiranga, agosto/2000 a setembro/2001 
Tabela 10 - Número e porcentagem de puérperas segundo o sexo do recém-nato. Hospitais: São Paulo, Vila Maria e Ipiranga, agosto/2000 a setembro/2001

Tabela 11 - Número e porcentagem de puérperas segundo o número de cigarros consumidos por dia em periodo anterior à última gestação. Hospitais: São Paulo, Vila Maria e Ipiranga, agosto/2000 a setembro/2001 ...73

Tabela 12 - Número e porcentagem de puérperas segundo o hábito de fumar estimado em anos. Hospitais: São Paulo, Vila Maria e Ipiranga, agosto/2000 a setembro/2001. 73

Tabela 13 - Número e porcentagem de puérperas segundo o número de cigarros consumidos por dia durante a última gestação, dentre o grupo de puérperas que fumava antes do último periodo gestacional. Hospitais: São Paulo, Vila Maria e Ipiranga, agosto/2000 a setembro/2001 ....74

Tabela 14 - Número e porcentagem de puérperas segundo o uso de drogas ilícitas. Hospitais: São Paulo, Vila Maria e Ipiranga, agosto/2000 a setembro/2001 75

Tabela 15 - Número e porcentagem de puérperas segundo a ocorrência de parto prematuro prévio. Hospitais: São Paulo, Vila Maria e Ipiranga, agosto/2000 a setembro/2001 75

Tabela 16 - Número e porcentagem de puérperas segundo a ocorrência de aborto prévio. Hospitais: São Paulo, Vila Maria e Ipiranga, agosto/2000 a setembro/2001 76

Tabela 17 - Número e porcentagem de puérperas segundo o número de gestações, incluindo a última. Hospitais: São Paulo, Vila Maria e Ipiranga, agosto/2000 a setembro/2001 
Tabela 18 - Número e porcentagem de puérperas segundo o número de partos concluídos, excluindo-se a última parturição. Hospitais: São Paulo, Vila Maria e Ipiranga, agosto/2000 a setembro/2001.

Tabela 19 - Número e porcentagem de puérperas segundo a ocorrência de infecções do trato genitourinário durante o último periodo gestacional. Hospitais: São Paulo, Vila Maria e Ipiranga, agosto/2000 a setembro/2001 ....78

Tabela 20 - Número e porcentagem de puérperas segundo a ocorrência de diabetes mellitus. Hospitais: São Paulo, Vila Maria e Ipiranga, agosto/2000 a setembro/2001

Tabela 21 - Número e porcentagem de puérperas segundo a ocorrência de hipertensão arterial. Hospitais: São Paulo, Vila Maria e Ipiranga, agosto/2000 a setembro/2001 .79

Tabela 22 - Número e porcentagem de puérperas segundo o nível de escolaridade materna. Hospitais: São Paulo, Vila Maria e Ipiranga, agosto/2000 a setembro/2001

Tabela 23 - Número e porcentagem de puérperas segundo a ocorrência do parto a pré-termo, peso do bebê ao nascer inferior a 2.500 gramas e variáveis demográficas. Hospitais: São Paulo, Vila Maria e Ipiranga, agosto/2000 a setembro/2001

Tabela 24 - Número e porcentagem de puérperas segundo a ocorrência do parto a pré-termo, peso do bebê ao nascer inferior a 2.500 gramas e variáveis relacionadas aos cuidados pré-natais. Hospitais: São Paulo, Vila Maria e Ipiranga, agosto/2000 a setembro/2001 82

Tabela 25 - Número e porcentagem de puérperas segundo a ocorrência do parto a pré-termo, peso do bebê ao nascer inferior a 2.500 gramas e variáveis de interesse. Hospitais: São Paulo, Vila Maria e Ipiranga, agosto/2000 a setembro/2001 
Tabela 26 - Número e porcentagem de puérperas segundo a ocorrência do parto a pré-termo, peso do bebê ao nascer inferior a 2.500 gramas e variáveis relacionadas ao uso de drogas ilícitas e tabaco. Hospitais: São Paulo, Vila Maria e Ipiranga, agosto/2000 a setembro/200 I 84

Tabela 27 - Número e porcentagem de puérperas segundo a ocorrência do parto a pré-termo, peso do bebê ao nascer inferior a 2.500 gramas e variáveis relacionadas à história reprodutiva. Hospitais: São Paulo, Vila Maria e Ipiranga, agosto/2000 a setembro/2001 86

Tabela 28 - Número e porcentagem de puérperas segundo a ocorrência do parto a pré-termo, peso do bebê ao nascer inferior a 2.500 gramas e variáveis relacionadas a intercorrências clínicas. Hospitais: São Paulo, Vila Maria e Ipiranga, agosto/2000 a setembro/2001

Tabela 29 - Número e porcentagem de puérperas segundo a ocorrência do parto a pré-termo, peso do bebê ao nascer inferior a 2.500 gramas e nivel de escolaridade materna. Hospitais: São Paulo, Vila Maria e Ipiranga, agosto/2000 a setembro/2001 .88

Tabela 30 - Número e porcentagem de puérperas segundo a ocorrência de doença periodontal. Hospitais: São Paulo, Vila Maria e Ipiranga, agosto/2000 a setembro/2001 89

Tabela 31 - Número e porcentagem de puérperas segundo a realização de tratamento periodontal anteriormente à última gestação. Hospitais: São Paulo, Vila Maria e Ipiranga, agosto/2000 a setembro/2001 89

Tabela 32 - Número e porcentagem de puérperas segundo a realização de tratamento periodontal durante o último periodo gestacional. Hospitais: São Paulo, Vila Maria e Ipiranga, agosto/2000 a setembro/2001 90

Tabela 33 - Número e porcentagem de puérperas segundo a ocorrência do parto a pré-termo, peso do bebê ao nascer inferior a 2.500 gramas e variáveis relacionadas à doença periodontal. Hospitais: São Paulo, Vila Maria e Ipiranga, agosto/2000 a setembro/2001 92 
Tabela 34 - Fatores de risco para a ocorrência do parto a pré-termo e peso do bebê ao nascer inferior a 2.500 gramas, no modelo final da Análise de Regressão Logística Binomial. Hospitais: São Paulo, Vila Maria e Ipiranga, agosto/2000 a setembro/2001 ................................... 94 


\section{LISTA DE SIGLAS, ABREVIATURAS E FÓRMULAS}

$\%$ - porcentagem ou por cento

$\geq-$ maior ou igual

$\leq-$ menor ou igual

$<-$ menor

$>-$ maior

A. actinomycetemcomitans - Actinobacillus actinomycetemcomitans

AA - ácido araquidônico

AA'P - American Academy of Periodontology

APCD - Associação Paulista dos Cirurgiões-Dentistas

B. forsythus - Bacteróides forsythus

c/ - com

$\mathrm{COX}$ - via da cicloxigenase

CPITN - Indice Periodontal Comunitário de Necessidade de Tratamento

DUM - data do primeiro dia da última menstruação confiável

Ec-Escherichia coli

ELAM - 1 - molécula - 1 de adesão do leucócito ao endotélio

ESI - Indice de Extensão e Severidade da Doença Periodontal

$\mathrm{E}=(\Sigma$ di. 100$) / \mathrm{n}$ para medir Extensão da Doença Periodontal, onde:

$\mathrm{di}=0$ se o nivel de inserção periodontal for igual a 1 milimetro, e

$\mathrm{di}=1$ se o nivel de inserção periodontal for maior que 1 milimetro, e

$\mathrm{n}=$ número de sítios efetivamente examinados, $\mathrm{e}$

$\Sigma=$ somatória

FNT $\alpha$ - fator de necrose tumoral alfa

FOUSP - Faculdade de Odontologia da Universidade de São Paulo

g-grama

HIV - virus da imunodeficiência humana

HPV - papiloma virus humano

IC - intervalo de confiança

ICAM - 1 - molécula - 1 de adesão intercelular

IgG - Imunoglobulina $G$

IgM - Imunoglobulina $\mathbf{M}$

Il $-1 \alpha$ - interleucina -1 alfa

Il - $1 \beta$ - interleucina -1 beta

Il-1 - interleucina-1

11-6 - interleucina-6

IMC - Índice de Massa Corpórea

jce - junçã̀o-cemento-esmalte

LPS - lipopolissacarideos

$\mathrm{mm}$ - milímetro

$\mathrm{N}$ - número de puérperas

$\mathrm{n}^{\mathrm{o}}$ - número

ns/nr - não sabe/não respondeu 
${ }^{\circ} \mathrm{C}$ - grau Celsius

OMS - Organização Mundial de Saúde

$\mathrm{OR}$ - odds ratio

$\mathrm{p}$ valor - valor de $\mathrm{p}$

$\mathrm{P}$. gingivalis - Porphyromonas gingivalis

P. intermedia - Prevotella intermedia

$\mathrm{Pg}-$ Porphyromonas gingivalis

PG - prostaglandina

PGD2 - prostaglandina D2

PGE2 - prostaglandina E2

PGF2 $\alpha$ - prostaglandina F2 alfa

PGF2 - prostaglandina F2

PGI2 - prostaglandina 12

s/ - sem

s/inf. - sem informação

$\mathrm{S}=\Sigma[\mathrm{di}(\mathrm{xi}-1)] / \sum \mathrm{di}$, para medir Severidade da Doença Periodontal, onde:

$\mathrm{xi}=$ valor em milímetro do nível de inserção periodontal em cada sítio

SEADE - Fundação Sistema Estadual de Análise de Dados

SUS - Sistema Único de Saúde

$T$. dentícola - Treponema dentícula

TPP - trabalho de parto prematuro propriamente dito

UNIFESP-EPM - Universidade Federal de São Paulo - Escola Paulista de Medicina $x^{2}-$ qui-quadrado 


\section{ÍNDICE}

1 INTRODUÇÃO 1

2 REVISÃO DA LITERATURA 5

2.1 A doença periodontal 5

2.1.1 Anatomia do periodonto 5

$\begin{array}{ll}\text { 2.1.2 Patogênese da doença periodontal } & 7\end{array}$

2.1.3 Mediadores químicos da doença periodontal 10

2.20 determinismo do parto e as infecções maternas como fatores predisponentes ao nascer prematuro e ao baixo peso ao nascer 15

$\begin{array}{ll}2.2 .10 \text { determinismo do parto } & 15\end{array}$

2.2.2 Infecções maternas como fatores predisponentes ao nascer prematuro e ao $\begin{array}{ll}\text { baixo peso ao nascer } & 18\end{array}$

2.3 A infecção periodontal como fator predisponente ao parto prematuro e ao baixo peso ao nascer $\quad 24$

3 OBJETIVOS

4 MATERIAL E MÉTODO

4.1 População de estudo 38

4.1.1 Seleção de pacientes $\quad 38$

4.1.2 Definição de caso/controle $\quad 41$

$\begin{array}{ll}4.2 \text { Variáveis } & 41\end{array}$

4.3 Procedimentos metodológicos $\quad 47$

4.3.1 Coleta dos dados $\quad 47$

4.3.2 Execução da entrevista $\quad 48$

4.3.3 Execução da consulta ao prontuário hospitalar 52

4.3.4 Execução do exame clínico periodontal 52

4.3.5 Análise dos dados $\quad 61$

$\begin{array}{ll}4.3 .6 \text { Aspectos éticos } & 63\end{array}$ 
5.1 Aspectos relacionados a características individuais, história reprodutiva e intercorrências clínicas 65

5.1.1 Descrição da população de estudo 65

5.1.2 Associação de variáveis 80

5.2 Aspectos relacionados às condições periodontais 88

5.2.1 Descrição da população de estudo 88

5.2.2 Associação de variáveis 91

5.2.3 Severidade da doença periodontal 93

5.2.4 Extensão da doença periodontal 93

5.3 Análise de Regressão Logística Binomial 94

6 DISCUSSÃO 95

7 CONCLUSÕES 101

8 REFERÊNCIAS BIBLIOGRÁFICAS $\quad 102$ ANEXOS

Anexo 1 - Ficha para entrevista inicial $\quad \mathrm{Al}$

Anexo 2 - Ficha para consulta inicial ao prontuário hospitalar A2

Anexo 3 - Termo de consentimento informado A3

Anexo 4 - Ficha de pesquisa avançada $\quad$ A4

Anexo 5 - Ficha para consulta avançada ao prontuário hospitalar A6

Anexo 6-Ficha para registro periodontal A8

Anexo 7 - Termo de aceitação da UNIFESP - EPM A9

Anexo 8 - Termo de aceitação da FOUSP $\quad$ A10

Anexo 9 - Termo de aceitação da APCD A11 


\section{INTRODUÇÃO}

A prematuridade, considerada como a principal causa de morbidade e mortalidade perinatal (CREASY e MERKATZ ${ }^{21}$ 1990; MORRISON ${ }^{76}$ 1990), contribui com 50 a $70 \%$ para a mortalidade neonatal (HOFFMAN e BAKKTEIG ${ }^{43}$ 1984). Associada ao baixo peso ao nascer, constitui problema de especial interesse para a saúde pública.

Discrepantes prevalências de prematuridade têm sido relatadas por diferentes estudos epidemiológicos. As diversas condições socioeconômicas e culturais das gestantes, as diferenças geográficas encontradas entre diferentes grupos populacionais, a etnia, bem como os variados tipos de assistência pré-natal disponibilizados às gestantes durante o período gestacional podem justificar as discrepantes prevalências de partos prematuros e de nascimentos de baixo peso.

Nos paises desenvolvidos, o parto a pré-termo ocorre em aproximadamente $8 \%$ a $10 \%$ das gestações (BERKOWITZ e PAPIERNIK ${ }^{9}$ 1993). Na América Latina, há relatos de índices mais elevados, situados entre 10\% e 43\% (ALTHABE e SCHWARCZ ${ }^{2}$ 1978).

No Brasil, dados divulgados pela Fundação Sistema Estadual de Análise de Dados (SEADE ${ }^{107}$ 1994) revelaram que no Estado de São Paulo a prevalência de recém-nascidos prematuros atingiu cerca de $11 \%$ do total de nascidos vivos no ano de 1993. Em levantamento feito na Universidade Federal de São Paulo - Escola Paulista de Medicina (UNIFESP-EPM), verificou-se uma prevalência de partos prematuros em torno de $20 \%$ a $22 \%$ (SOUZA et al. ${ }^{115}$ 1995). No ano de 1982 , a prevalência de baixo peso corporal ao nascimento encontrada no Brasil foi de 9\% (KRAMER ${ }^{48} 1987$ ). 
Embora ocorra um melhor entendimento dos fatores envolvidos no processo de parturição, bem como uma maior disponibilidade de recursos terapêuticos ao obstetra para promover o bloqueio do trabalho de parto, não tem sido observado um declínio na prevalência da prematuridade nos últimos 50 anos (CRAIGO ${ }^{20}$ 1996). Ademais, em um número expressivo de partos prematuros, o fator predisponente não é identificado (CHAMBERLAIN ${ }^{14}$ 1984; STUBLEFIELD $^{117} 1984$ MAIN $^{61} 1988$ ).

A etiologia da prematuridade e do baixo peso ao nascer é complexa. Embora muitos partos pré-termos estejam claramente associados a causas específicas ou a situações em que múltiplos fatores estão envolvidos, uma grande parcela das ocorrências de prematuridade ainda permanece sem uma causa definida (RUSH et al. $\left.^{105} 1976\right)$.

Dentre os fatores de risco associados à ocorrência de episódios indesejáveis durante 0 periodo gestacional, diversos estudos e evidências clínicas sustentam o importante papel que as infeç̧ões maternas exercem sobre o nascer prematuro e o nascimento de bebês com baixo peso (HILLIER et al. ${ }^{41}$ 1995; GOLDENBERG et al. $^{34} 2000$; SOBEL ${ }^{114} 2000$ ).

A ocorrência de infecções maternas clinicamente detectáveis, através da atuação de microrganismos ou de suas endotoxinas, pode provocar resposta inflamatória tecidual exacerbada associada à liberação de interleucina-1 (IL-1), prostaglandinas (PG) e fator de necrose tumoral alfa (FNT $\alpha$ ), mediadores quimicos envolvidos também no desencadeamento do parto. 
Entretanto, a constante observação da ocorrência de infiltração neutrofilica nas membranas corioamnióticas (corioamnionite histológica), de infecções clínicas nos neonatos prematuros, de culturas bacterianas positivas do líquido amniótico e de membranas corioamnióticas (mesmo na presença de membranas íntegras) e de numerosos marcadores bioquímicos de infeç̧ão (citocinas proinflamatórias, PGE2), tanto no líquido amniótico como no soro de mulheres com ocorrência de parto prematuro, tem levado à conclusão de que uma grande parcela dos partos prematuros pode ser causada por uma infeç̧ão de origem desconhecida, mesmo na ausência de qualquer sinal clínico ou subclínico de infeç̧ão (GIBBS ${ }^{32} 2001$ ).

Diversos trabalhos sobre a patogênese da doença periodontal demonstram que a presença de bactérias periodontopatogênicas, através de seus componentes bacterianos (lipopolissacarídeos e endotoxinas), desencadeia uma resposta imune-inflamatória caracterizada pela liberação de mediadores inflamatórios, tais como citocinas, produtos do ácido araquidônico (prostaglandinas), proteínas do sistema complemento e outras proteases plasmáticas, sendo estes os principais fatores associados com a destruição do tecido periodontal (PAGE ${ }^{90}$ 1991; OFFENBACHER et al. ${ }^{86} 1996 \mathrm{~b}$; LINDHE $\left.^{55} 1999 \mathrm{~b}\right)$.

Assim, considerando que os tecidos periodontais, frente à colonização microbiana das superficies dos dentes, ao suscitarem uma resposta inflamatória, atuam como reservatórios de mediadores químicos em elevadas concentrações, a presença da infecção periodontal pode representar um caminho adicional de exposição infecciosa/inflamatória para a unidade feto-placentária (OFFENBACHER et al. $\left.{ }^{86} 1996 \mathrm{~b}\right)$. 
Embora a doença periodontal em gestantes, dentre as diversas intercorrências clínicas predisponentes à prematuridade, esteja recebendo uma atenção considerável como fator de risco potencial para o nascer prematuro (OFFENBACHER et al. ${ }^{86}$ 1996b), somente através da realização de novos estudos epidemiológicos essa possivel associação poderá ser melhor avaliada. 


\section{REVISÃO DA LITERATURA}

Objetivando maior clareza na exposição, o presente capítulo foi dividido em três subitens: 1) A doença periodontal; 2) O determinismo do parto e as infecções maternas como fatores predisponentes ao nascer prematuro e ao baixo peso ao nascer; 3) A infecção periodontal como fator predisponente ao parto prematuro e ao baixo peso ao nascer.

\subsection{A doença periodontal}

\subsubsection{Anatomia do periodonto}

O periodonto, também chamado "aparelho de inserção" ou "tecidos de suporte dos dentes", tem como principal função prender, inserir o dente no tecido ósseo da maxila e mandíbula (periodonto de sustentação) e manter a integridade da superficie da mucosa mastigatória da cavidade bucal (periodonto de proteção) (LINDHE ${ }^{54}$ 1999a).

O periodonto de proteção é caracterizado pela gengiva livre e inserida, constituido por tecido epitelial e conjuntivo, enquanto o periodonto de sustentação é formado pelo osso alveolar, cemento radicular e ligamento periodontal (LINDHE ${ }^{54}$ 1999a).

Tanto o tecido conjuntivo gengival como o do ligamento periodontal caracterizam-se por abundante quantidade de fibras colágenas (cerca de $60 \%$ do seu volume), a presença de fibroblastos corresponde a apenas $5 \%$ de seu volume, enquanto $35 \%$ de seu volume é ocupado por vasos sanguíneos, nervos e matriz tecidual (LINDHE ${ }^{54}$ 1999a) (Figura 1). 

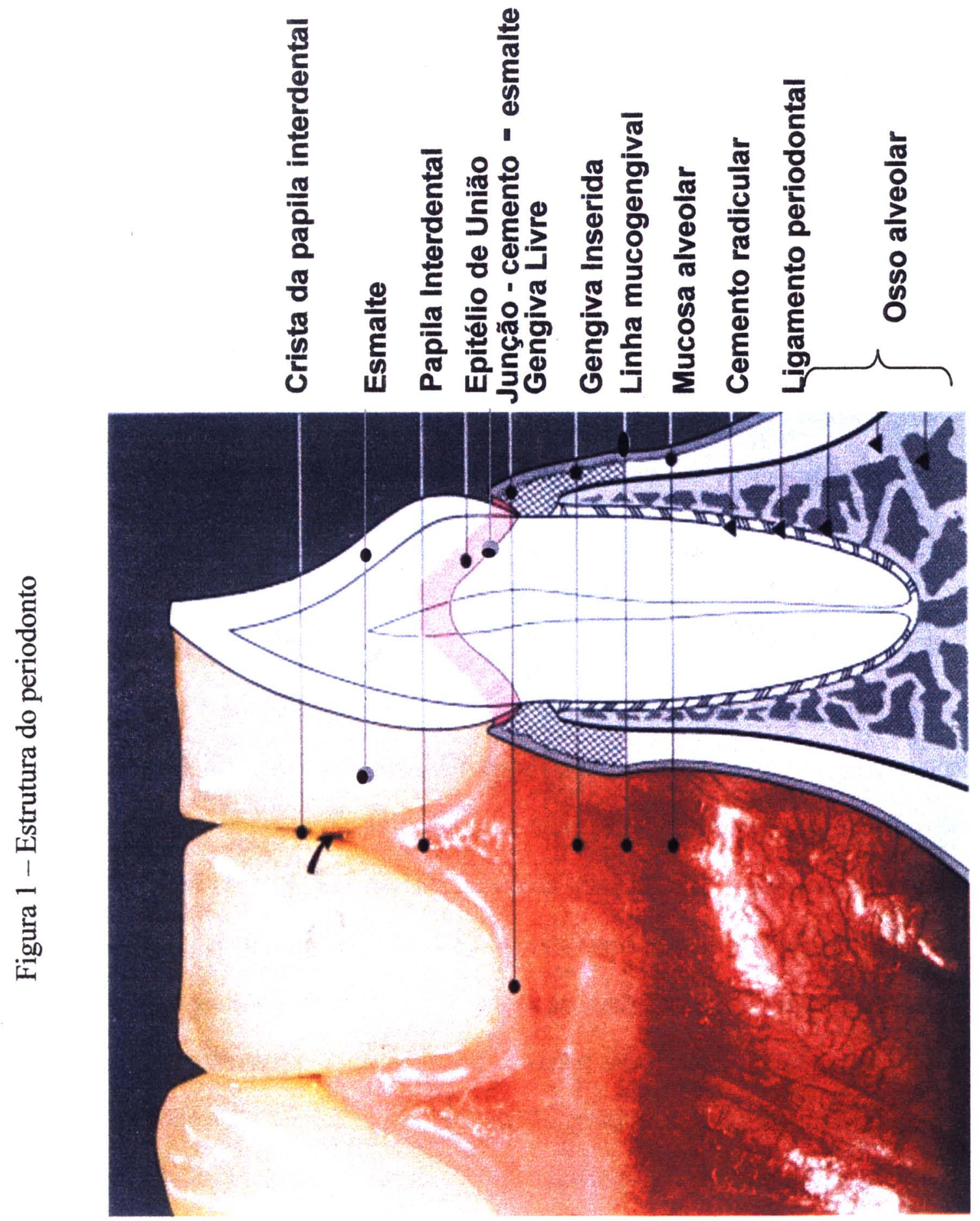


\subsubsection{Patogênese da doença periodontal}

A doença periodontal, enfermidade de natureza infecciosa, está associada primariamente à colonização das superficies dos dentes por bactérias anaeróbicas Gram negativas, que suscitam uma resposta inflamatória a qual pode acarretar a destruição dos tecidos periodontais (LINDHE ${ }^{55}$ 1999b; OFFENBACHER ${ }^{85}$ 1996a; PAGE $\left.^{90} 1991\right)$.

Desde 1998, um novo paradigma da patogênese da doença periodontal vem sendo discutido, sendo ressaltada a participação de vários fatores que podem influenciar a iniciação, a taxa de progressão e as características clínicas da doença periodontal, assim como sua resposta ao tratamento. Tais fatores são especificidade e patogenicidade da flora microbiana envolvida, resposta imune-inflamatória do hospedeiro, fatores de risco ambientais e adquiridos, características do metabolismo dos tecidos conjuntivo e ósseo alveolar, bem como fatores de risco genéticos (LINDHE $^{55}$ 1999b; WILLIAMS ${ }^{121} 1998$ ).

O acúmulo de placa bacteriana (depósitos bacterianos) na superficie dental atua como um agente irritativo (flogógeno) e desencadeia a resposta inflamatória/ imunológica no tecido gengival adjacente. O processo inflamatório gengival envolve a liberação de mediadores químicos que desencadeiam alterações no plexo microvascular (arteríolas, capilares e vênulas), caracterizadas por aumento do fluxo sanguíneo local, vasodilatação e aumento da permeabilidade vascular. Em associação às modificações do fluxo vascular, diversos mediadores químicos e fatores quimiotáticos de origem microbiana ou de sistemas do hospedeiro estimulam a expressão de moléculas de adesão nas células endoteliais (molécula-1 de adesão do leucócito ao endotélio - ELAM-1 e molécula-1 de adesão intercelular - ICAM-1) e 
nos leucócitos. Isso favorece a adesão à parede vascular e a migração das células inflamatórias para 0 meio extravascular, originando 0 exsudato inflamatório (LINDHE $^{55}$ 1999b; OFFENBACHER ${ }^{85}$ 1996a; PAGE $^{90} 1991$ ).

À medida que a deposição da placa bacteriana sobre o dente se perpetua, tornando-se estruturalmente mais complexa, os fenômenos inflamatórios se acentuam, podendo ser observadas diversas alterações no exsudato inflamatório, tais como um aumento em seu volume (LINDHE ${ }^{55} 1999$ b).

As alterações teciduais observadas durante o desenvolvimento da doença periodontal podem ser classificadas em quatro estágios distintos, considerando-se evidências clínicas e histopatológicas: estágio inicial, precoce, lesão gengival estabelecida (gengivite) e lesão periodontal avançada (periodontite) (LINDHE ${ }^{55}$ 1999b).

Na lesão inicial, após o acúmulo de placa bacteriana por 24 horas, nota-se dilatação do plexo vascular dentogengival e presença de infiltrado inflamatório com predomínio de neutrófilos. Após dois a quatro dias do início do acúmulo de placa, a resposta celular fica mais evidente, sendo os linfócitos as células predominantes (LINDHE ${ }^{55}$ 1999b).

Com a perpetuação da placa bacteriana, ao final de sete dias o infiltrado inflamatório, predominantemente linfoplasmocitário, chega a representar $15 \%$ do volume do tecido conjuntivo, podendo já ser notada a ocorrência de destruição dos fibroblastos e do colágeno tecidual gengival (lesão gengival precoce) (LINDHE ${ }^{55}$ 1999b).

Embora os dois primeiros estágios da doença periodontal sejam subclínicos, ao final do estágio precoce as alterações inflamatórias começam a ser observadas 
durante a realização do exame clínico periodontal. Essas alterações podem ser clinicamente detectadas pela presença de leve edema e pelo aumento do fluxo do fluido crevicular gengival (LINDHE $\left.{ }^{55} 1999 b\right)$.

No terceiro estágio, denominado de lesão gengival estabelecida (gengivite), observa-se intensificação do estado inflamatório à medida que a exposição à placa bacteriana persiste. Nessa fase, a quantidade de exsudato inflamatório com predomínio de linfócitos, plasmócitos e macrófagos está aumentada, e grande destruição tecidual gengival é evidenciada tanto clínica como histologicamente. Clinicamente, notam-se vermelhidão e tumefação gengival e uma maior tendência de sangramento dos tecidos moles à sondagem delicada da margem gengival (LINDHE $\left.{ }^{55} 1999 b\right)$.

O estágio final desse processo é conhecido como lesão avançada (periodontite), caracterizado tanto pela contaminação do cemento radicular como pela presença de bolsa periodontal, reabsorção óssea da crista alveolar e destruição do ligamento periodontal, quadro associado aos danos inflamatórios e imunopatológicos teciduais (LINDHE $\left.{ }^{55} 1999 \mathrm{~b}\right)$.

Essas alterações teciduais podem ser verificadas clinicamente utilizando-se indices que avaliam o sangramento à sondagem, os niveis de inserção periodontal e o aumento de profundidade de sondagem. Conforme a severidade da doença periodontal avança, nota-se também aumento da mobilidade do elemento dental (LINDHE ${ }^{55}$ 1999b).

Diversos trabalhos sobre a patogênese da doença periodontal levaram à hipótese de que as bactérias periodontopatogênicas, através de lipopolissacarídeos (LPS) e endotoxinas, causam destruição do tecido periodontal pela ativação de 
células de defesa e sistemas que sintetizam enzimas e outras moléculas. Apesar de os componentes bacterianos deflagrarem o processo inflamatório, mediadores químicos, tais como citocinas, produtos do ácido araquidônico, sistema complemento e outras proteases plasmáticas, perpetuam e amplificam a resposta inflamatória. Dessa maneira, a inflamação representa a manifestação de uma atividade coletiva que envolve a defesa do hospedeiro frente ao influxo de substâncias bacterianas nos tecidos periodontais. A presença contínua dos microrganismos é essencial para a manutenção desse processo. Essa reação inflamatória tem papel importante na eliminação do agente etiológico e na tentativa de restabelecer a normalidade aos tecidos (LINDHE ${ }^{55}$ 1999b; OFFENBACHER ${ }^{85}$ 1996a; PAGE ${ }^{90}$ 1991; PAGE $^{91}$ 1998; OFFENBACHER et al. ${ }^{84}$ 1993; SEYMOUR et al. ${ }^{109} 1993$ ).

\subsubsection{Mediadores químicos da doença periodontal}

Os mediadores químicos (moléculas endógenas) são importantes na amplificação e perpetuação da resposta inflamatória, representando os principais fatores associados à destruição periodontal. Podem ter tanto origem plasmática (complemento ativado e outras proteases plasmáticas) como celular. As principais células responsáveis pela produção e secreção de mediadores químicos são os leucócitos ativados e fibroblastos residentes no tecido conjuntivo. A interleucina-1 (IL-1), o fator de necrose tumoral- $\alpha$ (FNT- $\alpha$ ) e as prostaglandinas (PG) são os três mediadores mais envolvidos na patogênese da doença periodontal (OFFENBACHER $^{85}$ 1996a; PAGE ${ }^{90}$ 1991; STASHENKO et al. ${ }^{116} 1987$; LINDEMANN et al. ${ }^{53} 1988$ ). 


\subsubsection{Interleucina-1 (IL-1)}

O envolvimento da interleucina-1 (IL-1) na patogênese da doença periodontal tem sido estudado há muito tempo, devido à semelhança entre o seu conhecido efeito biológico e as manifestações observadas nesse tipo de doença infecciosa. Existem dois tipos de $\mathbb{I L}-1$ (IL-1 $\alpha$ e $\mathbb{L}-1 \beta$ ), codificadas por genes distintos. Apesar de as interleucinas $1 \alpha$ e $1 \beta$ terem apenas $27 \%$ de homologia na sua seqúência de aminoácidos, elas se ligam com comparável afinidade a receptores comuns encontrados em muitas células. Portanto, não é surpresa que atividades pró-inflamatórias e outras atividades biológicas possam ser observadas em ambos os tipos de IL-1 (OFFENBACHER ${ }^{85}$ 1996a; PAGE $^{90} 1991$ ).

A IL-1 é produzida predominantemente por macrófagos ativados por substâncias microbianas, por complexos imunes e outras citocinas. Linfócitos, plaquetas, fibroblastos, queratinócitos e células endoteliais também podem sintetizar esse mediador químico quando estimulados. A produção de $\mathbb{I L}-1$ é especialmente importante em infeç̧ões com Gram negativos, como é o caso da doença periodontal (periodontite). Os efeitos pró-inflamatórios das interleucinas têm sido descritos por diversos autores (OFFENBACHER ${ }^{85}$ 1996a; PAGE $^{90}$ 1991; TAKAHASHI et al. ${ }^{118}$ 1994; HAYASHI et al. ${ }^{39} 1994$; ISHIDA et al. ${ }^{45} 1993$; HILLMANN et al. ${ }^{42} 1995$; JANDINSKI et al. ${ }^{46}$ 1991; MATSUKI et al. ${ }^{64} 1993$; SIMS et al. ${ }^{111} 1988$; LINDEMANN et al. ${ }^{53} 1988$; RICHARDS e RUTHERFORD ${ }^{94}, 1988$; MASADA et al. $\left.^{63} 1990\right)$ e são a seguir delineados:

- atuam aumentando a expressão de moléculas de adesão nas células endoteliais, nos leucócitos e nos fibroblastos, favorecendo o recrutamento e a manutenção dessas células no sitio da inflamação; 
- induzem a sintese de prostaglandinas E2 (PGE2) por macrófagos e fibroblastos gengivais, levando ao aumento da permeabilidade vascular e à desmineralização óssea;

- apresentam efeito catabólico, como desmineralização e reabsorção óssea in vitro e indução de proteinases por células de origem mesenquimal, resultando na degradação tecidual;

- facilitam a apresentação de antígenos e a ativação de linfócitos T e B, promovendo ativação, proliferação, expansão clonal e secreção de anticorpos.

\subsubsection{Prostaglandina E2 (PGE2)}

A prostaglandina E2 (PGE2) é um produto do metabolismo do ácido araquidônico (AA), um ácido graxo poliinsaturado com 20 radicais carbono, derivado diretamente de fontes dietéticas ou da conversão de um ácido graxo essencial denominado "ácido linoléico". O AA não ocorre sob a forma livre nas células, sendo normalmente esterificado nos fosfolipídeos de membrana e liberado mediante a ativação de fosfolipases celulares, tanto por estímulos mecânicos, químicos ou físicos, como por outros mediadores (complemento 5a). Seus produtos atuam como hormônios de curto alcance, pois, além de rapidamente formados, exercem seus efeitos localmente e, em seguida, decaem espontaneamente ou são destruidos por meio de enzimas (COTRAN et al. ${ }^{18}$ 1996; SIQUEIRA JR e DANTAS $^{112} 2000$;. OFFENBACHER et al. ${ }^{84}$ 1993; SEIBERT e MASFERRER ${ }^{108}$ 1994; GIERSE et al. $\left.{ }^{33} 1995\right)$.

O metabolismo do AA segue duas vias principais denominadas segundo as enzimas que iniciam a reação: a via da cicloxigenase (COX) e a via da lipoxigenase. 
A via da COX conduz à geração de prostaglandinas (PGE2, PGD2, PGF2, PGI2) e de tromboxane. A via da lipoxigenase resulta na formação de leucotrienos (COTRAN et al. ${ }^{18}$ 1996; SIQUEIRA JR e DANTAS ${ }^{112}$ 2000; OFFENBACHER et al. $^{84}$ 1993; SEIBERT e MASFERRER ${ }^{108} 1994$; GIERSE et al. $\left.{ }^{33} 1995\right)$.

Células como fibroblastos e monócitos possuem altos niveis de AA e COX, podendo, portanto, secretar grandes quantidades de PGE2 atuantes na magnitude do processo inflamatório. Esse potencial contrasta com outros tipos de células que possuem baixos níveis de atividade de COX (COTRAN et al. ${ }^{18}$ 1996; SIQUEIRA JR e DANTAS ${ }^{112}$ 2000; OFFENBACHER et al ${ }^{84}$ 1993; SEIBERT e MASFERRER ${ }^{108}$ 1994; GIERSE et al. ${ }^{33}$ 1995; WILLIAMS e PECK ${ }^{122}$ 1977).

As PGE2 têm diversos efeitos pró-inflamatórios e imunomoduladores. A maioria das alterações inflamatórias que ocorrem na doença periodontal (vermelhidão, edema, degradação de colágeno e perda óssea alveolar) pode ser causada somente pela presença e ação direta das PGE2 (OFFENBACHER et al. ${ }^{80}$ 1981; OFFENBACHER et al. ${ }^{84}$ 1993; OFFENBACHER ${ }^{85}$ 1996a).

As PGE2, ao induzirem vasodilatação e aumento da permeabilidade vascular, levam à ocorrência de edema e vermelhidão tecidual. Também atuam na infiltração de células inflamatórias no tecido agredido, agindo na permanência dessas células no local e não na sua quimiotaxia. Induzem ainda a sintese de metaloproteinases, que degradam a matriz extracelular tecidual levando à destruição do tecido conjuntivo. No tecido ósseo, as PGE2 estimulam a reabsorção óssea osteoclástica (COTRAN et al. ${ }^{18}$ 1996; SIQUEIRA JR e DANTAS ${ }^{112}$ 2000; WILLIAMS e PECK ${ }^{122} 1977$; RIFKIN et al. ${ }^{96} 1980$; DIETRICH et al. ${ }^{28} 1975$; 


\subsubsection{Fator de Necrose Tumoral $\alpha$ (FNT- $\alpha)$}

O fator de necrose tumoral- $\alpha$ (FNT- $\alpha)$ é um mediador do processo inflamatório que atua conjuntamente com a IL-1, sendo produzido por macrófagos após sua ativação por componentes de bactérias Gram negativas, especialmente lipopolissacarídeos (LPS). Esse mediador tem um amplo espectro de ação em leucócitos, células endoteliais e células do tecido conjuntivo. Apesar de não ser tão potente como a IL-1, pode estimular a proliferação de precursores de osteoclastos e atuar nos osteoclastos maduros para estimular a reabsorção óssea. O FNT- $\alpha$ aumenta a resposta dos leucócitos a agentes quimiotáticos, bem como facilita a degranulação de neutrófilos e a aderência de leucócitos na parede de células endoteliais. Aumenta também a permeabilidade vascular e estimula as células endoteliais a produzir $\mathrm{IL}-1$ ${\text { (COTRAN et } \text { al. }^{18} \text { 1996; SIQUEIRA JR e } \text { DANTAS }^{112} \text { 2000; PAGE }}^{90}$ 1991; LEIBOVICH et al. ${ }^{52}$ 1987).

A participação do FNT- $\alpha$ na destruição tecidual provocada pela doença periodontal é menos documentada do que a atuação da IL-1, embora existam evidências importantes de seu papel nessa doença (PAGE ${ }^{90}$ 1991; OFFENBACHER $\left.^{85} 1996 \mathrm{a}\right)$.

\subsection{O determinismo do parto e as infecções maternas como fatores} predisponentes ao nascer prematuro e ao baixo peso ao nascer

\subsubsection{O determinismo do parto}

O processo fisiológico que desencadeia o início do trabalho de parto representa um grande enigma para os obstetras. Não está ainda definida a causa primária do seu determinismo, sugerindo que múltiplos fatores, complexos e inter- 
-relacionados, estejam envolvidos (NEME ${ }^{78} 1985$ REZENDE $\left.^{93} 1995\right)$.

Sabe-se que niveis adequados de progesterona são necessários para manutenção do útero quiescente durante a gestação, pois esse hormônio atua diminuindo a contratilidade uterina. Já o aumento dos níveis de estrógeno estimula a síntese de seus próprios receptores, o que acarreta a resposta miometrial ao hormônio, aumentando a contratilidade $\left(\right.$ NEME $\left.^{78} 1985\right)$.

Embora vários estudos realizados ao longo dos anos em mamiferos demonstrem importante associação entre modificações nos níveis de estrógeno e progesterona e o início da parturição, em estudos desenvolvidos em humanos, a queda dos niveis de progesterona parece não desempenhar o mesmo papel fundamental desencadeante do parto (CUNNINGHAM et al. ${ }^{22} 2001$ ).

Dentro desse contexto, o deflagrar da parturição não pode mais ser considerado apenas em termos de funcionamento da contratilidade miometrial. Alterações bioquímicas do tecido conjuntivo também devem ser incluidas, levando-se em consideração a ocorrência de modificações mais insidiosas do que as observadas na musculatura uterina (REZENDE $\left.{ }^{93} 1995\right)$.

Levando-se em conta que, no início do trabalho de parto, são encontradas concentrações aumentadas de prostaglandina F2alfa (PGF2 $\alpha$ ) e de prostaglandina E2 (PGE2) no líquido amniótico, dentre as inúmeras teorias aventadas para explicar o determinismo do parto, a teoria prostaglandínica é considerada como uma das mais bem estabelecidas (REZENDE ${ }^{93}$ 1995). O provável mecanismo envolvido na síntese das prostaglandinas e o início do trabalho de parto está abaixo descrito:

1) através da ação da interleucina 1, considerada fator modulador intermediário da parturição, grande quantidade de ácido araquidônico é liberada a 
partir da hidrólise dos glicerofosfolipideos armazenados no âmnio. Uma pequena porção do ácido araquidônico serviria como precursor da PGE2 nas membranas fetais (cório e âmnio), enquanto concentrações maiores tomariam parte na formação da PGE2 e PGF2 $\alpha$ na decídua;

2) a PGE2 formada no âmnio propiciaria a liberação de ácido araquidônico tanto no cório como na decídua e facilitaria, assim, a secreção de PGE2 no cório e de PGE2 e PGF2 $\alpha$ na decídua;

3) qualquer estímulo que facilitasse a síntese de PGE2 nas membranas fetais, como hipóxia, infecção, solução hipertônica e ácido araquidônico, poderia dar início à série de eventos que culminaria na formação de PGF $2 \alpha$ pela decídua e/ou miométrio, assim como a distensão das fibras miometriais acarretaria um aumento na produção de prostaglandinas, explicando assim a ocorrência do parto a pré-termo;

4) a PGF $2 \alpha$, por sua vez, agindo diretamente no miométrio, daria início à contração uterina da parturição humana.

As contrações uterinas, tornando-se progressivamente mais fortes, poderiam ocasionar uma acidose e acentuar a liberação da enzima fosfolipase A2 dos lisossomos, que, atuando sobre os fosfolipídeos, promoveria novas liberações de ácido araquidônico.

A dilatação do colo uterino promoveria a liberação de ocitocina pela hipófise materna; as contrações uterinas, assim, uma vez iniciado clinicamente o parto, tornar-se-iam auto-induzidas.

Muito provavelmente as prostaglandinas também desempenham papel relevante na manutenção das contrações, participando ativamente na expulsão do concepto e da placenta e na involução uterina pós-parto (REZENDE $\left.{ }^{93} 1995\right)$. 


\subsubsection{Infecções maternas como fatores predisponentes ao nascer}

\section{prematuro e ao baixo peso ao nascer}

Múltiplas linhas de pesquisa sustentam o papel da infecção como um fator predisponente para o nascer prematuro (TAKEDA e TSUCHIYA ${ }^{119,120} 1953 \mathrm{a}, \mathrm{b}$; RIEDER e THOMAS ${ }^{95}$ 1960; McKAY e WONG ${ }^{67}$ 1963; SKARNES e HARPER ${ }^{113}$ 1972; KULLANDER ${ }^{49}$ 1977; OFFENBACHER et al. ${ }^{88}$ 1998b).

Através da utilização de modelos de gestação em animais, foi possivel demonstrar que a ocorrência de infecções em animais prenhes - principalmente por bactérias Gram negativas ou pela administração de seus produtos, como as endotoxinas e lipopolissacarideos - pode responder por muitos episódios indesejáveis durante o período gestacional, incluindo o aborto espontâneo, o trabalho de parto prematuro, o baixo peso ao nascimento, o retardo do crescimento fetal e as anomalias esqueléticas (TAKEDA e TSUCHIYA ${ }^{119,120}$ 1953a,b; RIEDER e THOMAS $^{95}$ 1960; MCKAY e WONG ${ }^{67}$ 1963; SKARNES e HARPER ${ }^{113}$ 1972; KULLANDER $\left.{ }^{49} 1977\right)$.

Após inoculação intra-uterina de Escherichia coli ou outros microrganismos em modelos de gestação em coelhas, uma infecção intra-uterina rápida, reproduzivel, acompanhada por septicemia materna, aborto e evidência histológica de inflamação pôde ser observada (DOMBROSKI et al. ${ }^{29} 1990$, MCDUFFIE et al. ${ }^{66} 1992$ ). Concentrações sensivelmente aumentadas de prostaglandinas (PG), interleucina-1 (IL-1) e fator de necrose tumoral alfa (FNT $\alpha$ ) no líquido amniótico também foram observadas similarmente ao que ocorre em humanos (MCDUFFIE et al. ${ }^{66}$ 1992).

Amostragens seqüenciais do líquido amniótico, após a inoculação de Estreptococo do grupo B em modelos de gestação em macacas Rhesus, exibiram 


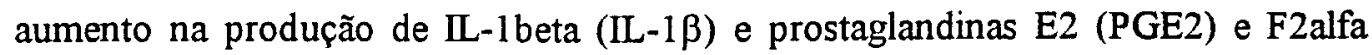
(PGF2 $\alpha$ ) concomitantemente ao aumento da contagem bacteriana. Os aumentos de citocinas e prostaglandinas observados precederam o desencadeamento das contrações musculares uterinas prematuras (GRAVETT et al ${ }^{37}$ 1994).

Utilizando modelo de gestação em hamster, LANNING et al. $^{51}$ (1983) demonstraram que o desenvolvimento embriológico ficava comprometido quando havia exposição a Escherichia coli, resultando em baixo peso, malformações fetais e abortos espontâneos.

YOUNG et al. ${ }^{123}$ (1996), em estudo desenvolvido com modelos de gestação em ovelhas (apresentam período gestacional de 147 dias), verificaram que a infusão exógena contínua de PGE2 a partir do $121^{\circ}$ dia da gestação ativava mecanismos hormonais e provocava a parturição precoce $(138,4 \pm 2,1$ dias). Para o grupo que recebia infusão contínua de substâncias salinas, a ocorrência do parto se deu no termo $(148,2 \pm 0,5$ dias $)$.

O desenvolvimento de experimentos em modelos animais forneceu a base para que associações similares em humanos fossem investigadas. Assim, diversos estudos têm demonstrado a capacidade que infecções agudas maternas têm para alcançar a unidade feto-placentária (útero, membranas corioamnióticas, placenta, líquido amniótico, pulmões e circulação fetais) (GOMEZ et al. ${ }^{35} 1995$; GOLDENBERG et al. ${ }^{34}$ 2000; SOBEL ${ }^{114}$ 2000; GIBBS $^{32} 2001$ ).

Embora evidências diretas de processo infeccioso matemo como fator predisponente ao parto prematuro possam ser apresentadas apenas em modelos de gestação em animais, a diversidade de infeç̧ões maternas em humanos associadas com a ocorrência de prematuridade torna biologicamente plausivel essa relação 
causal, ainda que indiretamente. A associação de infecções maternas desempenhando papel indesejado na gestação vem sendo estabelecida, tais como rubéola, shiguela, encefalite e pneumonia. Dentre esses processos infecciosos, agentes como Rubella e Campylobacter, por possuirem capacidade de atravessar a barreira placentária, são considerados abortiferos (BERKOWITZ e LASALA ${ }^{10}$ 1990).

Uma das mais importantes exposições infecciosas maternas que implica nascimento prematuro, ruptura prematura de membranas e baixo peso ao nascer é a infecção aguda do trato genitourinário, por sua capacidade de promover infecções uterinas principalmente pela migração cervical de bactérias da vagina para o espaço coriodecidual em algum momento da gestação (GOMEZ et al. ${ }^{35} 1995$; GOLDENBERG et al. ${ }^{34}$ 2000; SOBEL ${ }^{114}$ 2000; GIBBS $^{32} 2001$ ).

Dentre as infeç̧ões do trato genitourinário, numerosos estudos indicam uma associação entre a vaginose bacteriana clinicamente detectável - condição vaginal caracterizada pelo decréscimo da flora dominada por Lactobacillus e um aumento de anaeróbicos e espécies facultativas, incluindo Gardnerella vaginalis, Mobiluncus curtsii, Prevotella bivia e Bacteroides ureolyticus - e o nascimento prematuro (HILLIER et al. ${ }^{41}$ 1995; GRAVETT et al.$^{36}$ 1986; MEIS et al. ${ }^{68} 1995$; HOLST et al. ${ }^{44} 1994 ;$ GIBBS et al. ${ }^{31} 1992 ;$ ).

O estudo de MINKOFF et al. ${ }^{70}$ (1984) mostra que mães de recém-nascidos com baixo peso corporal apresentavam, com maior freqüência, espécimes de Bacteróides em culturas vaginais obtidas no início do $2^{\circ}$ trimestre de gravidez. Uma associação estatisticamente significativa foi observada entre a colonização vaginal com espécimes de Bacteróides e o parto pré-termo $(p<0,03)$, assim como com a ruptura prematura de membranas $(\mathrm{p}<0,01)$. 
HILLIER et al. ${ }^{41}$ (1995), em estudo de coorte, com a realização de culturas vaginais, evidenciaram a ocorrência de associação entre vaginose bacteriana e o parto prematuro com baixo peso ao nascer $(\mathrm{OR}=1,4$ e IC $95 \%=1,1$ a 1,8$)$.

Além das infecções vaginais, o aumento dos índices de prematuridade e a mortalidade perinatal também têm sido observados entre os fetos e recém-nascidos de gestantes portadoras de infecção do trato urinário (bacteriúria assintomática, cistite aguda e pielonefrite) $\left(\mathrm{NEME}^{78} 1985\right)$, desencadeadas principalmente por Estreptococo do grupo B (HANNAH et al. ${ }^{38} 1997$; GIBBS et al. ${ }^{31} 1992$ ).

ROMERO e MAZOR ${ }^{98}$ (1988a) concluíram que a ocorrência de bacteriúria assintomática promovia uma taxa $60 \%$ mais alta de baixo peso ao nascer (IC $95 \%=$ 1,4 a 1,9 ) e $90 \%$ mais alta de nascimentos prematuros (IC $95 \%=1,3$ a 2,9 ).

Com fatores de risco igualmente distribuídos entre gestantes, com exceção da presença de infecção urinária causada por Estreptococo do grupo B, MØLLER et al. ${ }^{59}$ (1984) observaram que eventos de ruptura prematura de membranas e de parto prematuro foram mais freqüentes entre aquelas com histórico de infecção.

Entretanto, a ocorrência de infecções agudas do trato genitourinário e, dentre elas, a vaginose bacteriana clinicamente detectável (considerada como uma das mais importantes exposições infecciosas maternas associadas ao nascer prematuro de baixo peso) pode explicar somente uma pequena parcela dos resultados gestacionais adversos (GOLDENBERG et al..$^{34} 2000$ ).

A ocorrência de casos subclínicos ou não detectáveis de vaginose bacteriana, eventos no pré-natal não relacionados a processos infecciosos ou outras formas de infecção também podem estar relacionados à ocorrência do parto prematuro associado ao baixo peso $\left(\mathrm{GIBBS}^{32} 2001\right)$. 
ROMERO et al. ${ }^{99}(1988 \mathrm{~b})$, ao observarem elevados niveis de PGE2 nos nascimentos prematuros de baixo peso, mesmo na ausência de infecções do trato genitourinário, clínicas ou subclinicas, propuseram a ocorrência de infecções de origem desconhecida como agente causal.

Dentre as evidências de infeç̧ão subclínica como principal causa de nascimentos prematuros não justificados, GIBBS $^{32}$ (2001) ressaltou que, no parto a pré-termo, ao comparar seus eventos com os envolvidos no parto no termo, evidencia-se uma ocorrência aumentada de: 1) infiltração neutrofilica nas membranas corioamnióticas (corioamnionite histológica); 2) infecções clinicamente evidentes nos neonatos prematuros; 3 ) culturas bacterianas positivas do líquido amniótico e de membranas corioamnióticas, mesmo na presença de membranas íntegras; e 4) numerosos marcadores bioquímicos de infeç̧ão (citocinas proinflamatórias, PGE2), tanto no líquido amniótico como no soro de mulheres com ocorrência de parto prematuro.

A hipótese que associa a infecção subclínica ao nascimento prematuro é a de que os próprios microrganismos ou suas toxinas, tais como endotoxinas (lipopolissacarídeos), entram na cavidade uterina durante a gravidez pela corrente sanguínea, a partir de um foco não-genital ou por uma rota ascendente do trato genital inferior (casos subclínicos ou não detectáveis de vaginose bacteriana) (GIBBS $^{32}$ 2001). Microrganismos ou seus produtos interagem provavelmente na decídua, estimulando a produção de prostaglandinas, embora seja possível a presença de interações (provavelmente mediadas pelas citocinas) nas membranas, levando à produção de mais prostaglandinas, bem como à contração prematura do músculo uterino (BEJAR et al. ${ }^{7} 1981$; LAMONT et al. ${ }^{50} 1985$; BENNETT et al..$^{8} 1987$; 
ROMERO et al. $\left.{ }^{97,98,99,100} 1987,1988 a, b, 1989\right)$.

Ainda que as endotoxinas pareçam estar intimamente ligadas ao trabalho de parto prematuro associado com uma infecção, evidências consideráveis indicam um papel importante das citocinas como mediadoras bioquímicas no desencadeamento do parto prematuro na presença de um processo infeccioso, excluindo, dessa forma, as endotoxinas como as únicas responsáveis pela liberação de prostaglandinas (ROMERO et al. ${ }^{99} 1988 \mathrm{~b}$ ).

Diversos estudos têm investigado marcadores de infecção potencialmente sensíveis, no intuito de identificar a presença de processos infecciosos tanto em mulheres apresentando sinais e sintomas de trabalho de parto prematuro como em pacientes assintomáticas (geralmente em risco para o trabalho de parto prematuro) durante os cuidados pré-natais. Dentre as citocinas avaliadas, a interleucina-6 é provavelmente o marcador mais sensivel para infecção (MITCHELL et al. ${ }^{71} 1991$; HILLIER et al. ${ }^{40}$ 1993).

Tanto os macrófagos derivados da medula óssea presentes na decídua (BULMER e JOHNSON ${ }^{11}$ 1984) quanto o próprio tecido decidual apresentam potencial para produzir agentes bioativos, incluindo certas citocinas (IL-1 e o FNT $\alpha$ ) (CASEY et al. ${ }^{13}$ 1989). Estas podem servir como mediadores bioquímicos do trabalho de parto. Também é possivel que citocinas produzidas em sítios distantes possam alcançar a cavidade uterina e induzir a síntese de prostaglandinas.

A IL-6 estimula a liberação de prostaglandina em humanos pelo âmnio e pela decídua (MTTCHELL et al. ${ }^{71}$ 1991) e parece estar aumentada no líquido amniótico de mulheres com trabalho de parto prematuro associado com infeç̧ão (ROMERO et al. ${ }^{101} 1990$; HILLIER et al. ${ }^{40}$ 1993; ANDREWS et al. $\left..^{3,4} 1995 \mathrm{a}, \mathrm{b}\right)$, assim como em 
mulheres que experimentam aborto espontâneo (ROMERO et al. ${ }^{103}$ 1995).

HILLIER et al. ${ }^{40}$ (1993), em um estudo de 50 mulheres em trabalho de parto prematuro, relataram que a concentração média de $\mathrm{IL}-6$ no líquido amniótico foi mais alta quando o parto ocorria antes da $34^{\mathrm{a}}$ semana gestacional.

ROMERO et al. ${ }^{102}$ (1993) detectaram que a presença de IL-6 no líquido amniótico constitui um marcador seguro de infecção intra-uterina em mulheres com trabalho de parto prematuro e membranas intactas, assim como em mulheres com ruptura prematura de membranas.

MAZOR et al. ${ }^{65}$ (1990), ao avaliarem as concentrações de PGE2 e PGF2 $\alpha$ no líquido amniótico de 30 mulheres em trabalho de parto prematuro, demonstraram que, para as gestantes em trabalho de parto prematuro com presença de infecção intraamniótica, as concentrações de PGE2 e PGF2 $\alpha$ eram significativamente maiores em relação às concentrações encontradas nas gestantes com trabalho de parto prematuro sem a ocorrência de processo infeccioso.

Embora o nascimento prematuro possa ser mediado pela translocação de produtos bacterianos, as evidências apresentadas oferecem crédito ao papel potencial dos mediadores inflamatórios, tais como PGE2 e FNT $\alpha$, produzidos pela gestante(GIBBS ${ }^{32}$ 2001).

\subsection{A infecção periodontal como fator predisponente ao parto prematuro}

\section{e ao baixo peso ao nascer}

A doença periodontal, enfermidade de natureza infecciosa associada primariamente à colonização das superficies dos dentes por bactérias anaeróbicas Gram negativas, apresenta mecanismo biológico com potencial para afetar o 
desenvolvimento da gestação mesmo com ocorrência a distância (OFFENBACHER et al. $\left.{ }^{88} 1998 b\right)$.

Através de uma série de experimentos animais, foi possivel demonstrar que, embora o risco obstétrico esteja aumentado perante a presença de processos infecciosos agudos, a exposição crônica de patógenos bucais aumenta a possibilidade de complicações na prenhez de animais (OFFENBACHER et al. ${ }^{88}$ 1998b).

Com a hipótese de que uma sobrecarga de endotoxinas (lipopolissacarídeos-LPS), principal componente da parede celular de bactérias Gram negativas relacionadas à infecção periodontal, pudesse representar um desafio às condições de normalidade da gravidez, COLLINS et al. ${ }^{16}$ (1994b) avaliaram, através de experimento em modelo animal, o potencial deletério da inoculação intravenosa de lipopolissacarideos de Porphyromonas gingivalis $(\mathrm{Pg})$ e Escherichia coli $(\mathrm{Ec})$ na prenhez de hamsters. Através da inoculação de LPS de patógenos bucais ( $\mathrm{Pg})$, não foi possivel observar os mesmos efeitos destrutivos ocasionados pela inoculação de LPS de Ec, como febre e perda de peso em animais prenhes. Contudo, um aumento nas concentrações de PGE2 e FNT $\alpha$, assim como um concomitante decréscimo do peso fetal inversamente proporcional à extensão da resposta inflamatória foram evidenciados.

COLLINS et al. ${ }^{15}$ (1994a) demonstraram, em um outro modelo de gestação em hamster, que a presença de uma infecção localizada subcutânea (não disseminada), através da inoculação de bactérias patogênicas periodontais (Porphyromonas gingivalis), esteve associada com aumentadas concentrações de PGE2 e FNTa, diminuição do peso fetal em até $25 \%$, acréscimo significativo da embrioletalidade e aumento significativo na porcentagem de casos de reabsorção 
fetal. Uma correlação entre maiores concentrações de PGE2 e FNT $\alpha$ com menor peso fetal e maior porcentagem de placentas com fetos não vitais também pôde ser evidenciada.

Em outro trabalho utilizando modelo de gestação em hamster, COLLINS et al. ${ }^{17}$ (1995) avaliaram se a presença de uma infecção periodontal desenvolvida experimentalmente podia representar uma carga bacteriana suficiente para propiciar resultados gestacionais indesejáveis. Para o grupo de animais que desenvolveram periodontite, pôde-se observar a presença de um decréscimo significativo do peso fetal do grupo experimental em relação ao controle, além de uma sensivel elevação nos níveis de PGE2 e FNT $\alpha$ no líquido amniótico. Uma diminuição do crescimento fetal proporcionalmente comparável ao observado após a inoculação subcutânea de Porphyromonas gingivalis foi evidenciada.

Não foi estabelecida a origem da relação entre um processo infeccioso bucal e as mudanças no ambiente fetal: se é resultado da síntese de PGE2 e FNT $\alpha$ pelas células corioamniônicas induzidas pelos lipopolissacarideos oriundos da infecção periodontal e disseminadas pela corrente sanguínea, ou se os próprios sítios com infecção periodontal, ao produzirem mediadores inflamatórios, passam a atuar como fonte sistêmica potencial de citocinas fetotóxicas (COLLINS et al. ${ }^{15,16} 1994 \mathrm{a}, \mathrm{b}$ ).

Embora a periodontite seja de natureza crônica, dados obtidos a partir de estudos desenvolvidos em modelos animais demonstram que a exposição crônica a patógenos bucais aumenta a toxicidade feto-placentária durante a gravidez, fornecendo assim importantes evidências aos experimentos em humanos. Estes investigam a possibilidade de que, mesmo a distância, infeç̧ões bucais de baixa intensidade também possam desencadear processo inflamatório na unidade materna- 
-fetal humana de maneira análoga à vista na vaginose bacteriana (COLLINS et al. ${ }^{16,17}$ 1994b, 1995; OFFENBACHER et al. ${ }^{89}$ 2001; MADIANOS et al. ${ }^{60} 2001$ ).

Os niveis de PGE2 do fluido crevicular gengival como indicadores da severidade da doença periodontal têm sido descritos por muitos investigadores. $\mathrm{Na}$ presença de infecção/inflamação gengival, o fluxo do fluido crevicular gengival, que fisiologicamente ocorre ao redor dos dentes junto à margem gengival, sofre um aumento acompanhado da liberação de um maior volume de mediadores inflamatórios. Com o objetivo de determinar se os niveis de PGE2 do fluido crevicular gengival apresentam correlação com os níveis de PGE2 do líquido amniótico, DAMARÉ et al. ${ }^{24}(1995,1997)$ utilizaram amostras coletadas do fluido crevicular gengival e do líquido amniótico de dezoito gestantes no início do segundo trimestre de gravidez. Segundo os autores, através de análise de regressão linear, uma associação positiva foi encontrada entre os níveis de PGE2 amniótico e os do fluido crevicular gengival.

Um estudo de caso-controle com 124 gestantes e puérperas foi desenvolvido na Carolina do Norte (Estados Unidos) por OFFENBACHER et al. ${ }^{86}$ (1996b), com o propósito de determinar se a ocorrência da infecção periodontal materna poderia estar associada ao nascimento prematuro de baixo peso, controlando-se fatores de risco obstétricos conhecidos e variáveis de confusão. Dentre as 124 mulheres selecionadas, 93 apresentavam história gestacional atual ou pregressa de ocorrência de pelo menos um nascimento com peso inferior a 2.500 gramas e idade gestacional inferior a 37 semanas, decorrente de trabalho de parto prematuro ou ruptura prematura de membranas (caso); 31 mulheres tinham tido todos os nascimentos com peso igual ou superior a 2.500 gramas e não apresentavam história de trabalho de 
parto prematuro ou ruptura prematura de membranas (controle). As avaliações incluiram a investigação de um extenso grupo de fatores de risco, tais como uso de tabaco e de drogas ilícitas, consumo de álcool, nível de cuidados pré-natais, paridade, infeç̧ões genitourinárias e nutrição, além da realização de um exame periodontal completo. Mães do grupo caso tinham condições periodontais significantemente piores do que as do grupo controle. Através da realização de análise de regressão logistica múltipla, pôde-se determinar a magnitude do risco de nascimento prematuro de baixo peso atribuivel à infecção periodontal com relação a outros fatores de risco. Mães primíparas com perda de inserção periodontal de $3 \mathrm{~mm}$ ou mais, afetando pelo menos $60 \%$ dos sítios examinados, tinham risco 7,5 vezes maior de nascimentos prematuros de baixo peso. Segundo OFFENBACHER et al. ${ }^{86}$ (1996b), a extensão da doença periodontal esteve fortemente associada ao baixo peso ao nascer. A magnitude do efeito da infecção periodontal no peso de nascimento foi maior do que a do uso de tabaco ou consumo de álcool.

DASANAYAKE ${ }^{25}$ (1998), em um estudo de caso-controle na Tailândia, avaliou 110 puérperas, sendo consideradas como caso aquelas cujos bebês ao nascerem apresentaram peso inferior a 2.500 gramas; enquanto nas do grupo controle, o peso ao nascimento foi igual ou maior a 2.500 gramas. Casos e controles foram pareados por idade, estado civil, raça, paridade e número de gestações. Dados a respeito do uso de tabaco, consumo de álcool e café, nivel educacional, ocupação do marido e realização de tratamentos odontológicos durante a gravidez foram obtidos. A condição bucal foi avaliada pelo emprego do Índice Periodontal Comunitário de Necessidade de Tratamento (CPITN) (OMS). Após análise de 
regressão logistica multivariada, constatou-se que a presença de um maior número de sextantes saudáveis foi um fator de proteção contra o baixo peso ao nascer.

Com o objetivo de avaliar se a composição da placa bacteriana e a presença de mediadores inflamatórios no fluido crevicular gengival se diferenciavam entre mães com ocorrência do parto a pré-termo e peso do bebê ao nascer inferior a 2.500 gramas (caso) em relação a mães cujo parto foi no termo e peso do bebê ao nascer maior ou igual a 2.500 gramas (controle), OFFENBACHER et al. ${ }^{88}$ (1998b) desenvolveram estudo de caso-controle com 44 mulheres nos Estados Unidos. Quatro amostras do líquido crevicular gengival foram tomadas de cada participante, para análise das concentrações de PGE2 e $\Pi$ L-1 $\beta$ pelo método ELISA. Quatro amostras de placa bacteriana também foram obtidas de cada participante para análise da presença e quantificação de quatro microrganismos periodontopatogênicos $(P$. gingivalis, $B$. forsythus, $A$. actinomycetemcomitans e $T$. denticola), através do emprego de sonda de DNA. Um exame periodontal completo foi realizado, sendo considerado como doente periodontal o sítio que apresentasse um limiar de perda de inserção maior ou igual a $4 \mathrm{~mm}$. A doença periodontal foi mais severa nas mães do grupo caso, embora as diferenças nos níveis de inserção clínica não tenham alcançado significância estatística. Os níveis de PGE2 presentes no líquido crevicular gengival foram significantemente maiores nos casos do que nos controles, sendo para as primiparas inversamente proporcional à idade gestacional e ao peso de nascimento. Também foi observada uma tendência de níveis maiores de $\mathbb{L}-1 \beta$ nos casos, embora não significativa. Todas as mães do grupo caso apresentaram maiores níveis dos quatro patógenos avaliados. 
Por meio da realização de estudo de caso-controle, foi investigada a possível relação entre nascimentos prematuros de baixo peso e doença periodontal materna. A condição periodontal de um grupo de puérperas atendidas no Royal Hospitals Trust, ao leste de Londres (Inglaterra), foi avaliada com o auxilio do Índice Periodontal Comunitário de Necessidade de Tratamento (CPITN) (OMS). Dentre as puérperas com ocorrência do parto a pré-termo e baixo peso ao nascer, não foi detectada a presença de maior severidade na periodontite (DAVENPORT et al. ${ }^{26} 1998$ ).

A fim de determinar se a doença periodontal é um fator causal ao nascimento prematuro, um estudo prospectivo foi conduzido por JEFFCOAT et al. ${ }^{47}$ (2001) na Universidade do Alabama (Estados Unidos). Durante a 20ªna do período gestacional de 1.313 gestantes, realizaram-se exames pré-natais de rotina, coleta de informações sobre hábitos pessoais e exames periodontais. Gestantes com periodontite de grau leve a moderado exibiam entre 3 e 50 sítios com $3 \mathrm{~mm}$ ou mais de perda de inserção periodontal. Gestantes com mais de 50 sítios com $3 \mathrm{~mm}$ ou mais de perda de inserção eram classificadas como tendo periodontite severa ou generalizada. Através da realização de análise multivariada, após a parturição pôde-se observar que a periodontite materna foi um fator de risco independente para o nascer prematuro. Além disso, gestantes portadoras da forma severa de doença periodontal tinham 4,18 vezes maior risco de ocorrência de parto prematuro.

Destinados a determinar se a presença da infecção periodontal materna previamente ao parto, bem como a incidência de novos sítios infectados ou a sua progressão durante o período gestacional podem trazer um risco significativo à ocorrência da prematuridade e ao crescimento fetal, OFFENBACHER et al. ${ }^{89}$ (2001) realizaram estudo prospectivo de cinco anos na Carolina do Norte (Estados Unidos). 
Através da realização de exames periodontais completos antes da $26^{\mathrm{a}}$ semana gestacional e nas primeiras 48 horas pós-parto, foi possível avaliar a ocorrência de mudanças na condição periodontal durante esse periodo. Embora seus resultados sejam preliminares, através dos primeiros 814 partos, verificou-se que tanto a incidência de novos sítios infectados como a progressão da doença periodontal durante o periodo gestacional estão significativamente associadas a maiores prevalências de nascimentos prematuros, nascimentos com peso inferior a 2.500 gramas e menores pesos ao nascer por idade gestacional. Esse achado reforça a tese de que a presença da doença periodontal materna antes do parto, bem como seu agravamento durante o período gestacional, impõe um risco significante ao desenvolvimento fetal.

Através da utilização de sondas de DNA, a presença de quinze patógenos periodontais foi investigada na placa bacteriana materna amostrada logo após o parto. Anticorpos IgG maternos pós-parto e IgM fetais, obtidos do sangue do cordão umbilical, foram investigados para os patógenos maternos bucais identificados pelas sondas de DNA. A prevalência de oito patógenos periodontais foi semelhante entre puérperas com ocorrência do parto no termo e a pré-termo. Dentre os quinze organismos analisados, houve uma prevalência 2,9 vezes maior de soropositividade IgM para um ou mais organismos. Os organismos examinados faziam parte dos dois complexos bacterianos considerados como principais envolvidos no processo infeccioso periodontal. A falta de anticorpos maternos IgG para alguns organismos associados à doença periodontal foi relacionada a uma ocorrência aumentada de partos prematuros, achado compativel com o conceito de que anticorpos maternos protegem o feto contra exposição microbiana e evitam a ocorrência da 
prematuridade. Esses resultados apóiam a tese de que a infecção periodontal, na ausência de resposta materna quanto à produção de anticorpos, está associada com disseminação sistêmica de organismos bucais, que, ao alcançarem o feto, levam ao desencadeamento prematuro do parto (MADIANOS et al. ${ }^{60} 2001$ ).

Trezentas e cinqüenta e uma gestantes, na cidade de Santiago (Chile), entre 18 e 35 anos de idade, portadoras de periodontite marginal crônica, foram selecionadas antes de completarem 24 semanas de gestação. Quatrocentas e seis gestantes foram aleatoriamente encaminhadas para a realização de tratamento periodontal antes da $28^{\mathrm{a}}$ semana gestacional, enquanto 233 só receberam tratamento periodontal após o parto. Através dos registros médicos, foram obtidas informações a respeito de fatores de risco associados ao nascer prematuro de baixo peso. Não foram encontradas diferenças significativas em relação a condição nutricional, fumo, infecções genitourinárias, paridade e fato de serem primíparas, apresentarem história prévia de nascimentos prematuros de baixo peso ou abortos. A incidência total de nascimentos prematuros de baixo peso foi de 2,5\% para as pacientes com periodontite marginal tratada e $8,6 \%$ para as que não receberam tratamento periodontal previamente à parturição. As puérperas com ocorrência de parto prematuro de baixo peso eram portadoras de periodontite marginal significativamente mais severa do que a apresentada pelas puérperas com nascimentos no termo. As puérperas com parto prematuro apresentavam um risco relativo de 3,5 vezes para a prematuridade associada ao baixo peso ao nascer (LOPEZ et al. ${ }^{57}$ 2002).

MITCHELL-LEWIS et al. ${ }^{72}$ (2001) mostraram uma prevalência de $19,9 \%$ de nascimentos prematuros para puérperas portadoras de doença periodontal sem 
realização de tratamento periodontal. Para as portadoras de periodontite cujo tratamento periodontal foi realizado previamente a parturição, em apenas $13,5 \%$ a ocorrência do parto foi a pré-termo.

A possivel relação da infecção periodontal com partos prematuros e nascimentos de baixo peso foi investigada por SILVA et al. ${ }^{110}$ (2001) em uma comunidade de baixas condições socioeconômicas em Fortaleza (Brasil). Oitenta e nove grávidas no terceiro trimestre do periodo gestacional, com idade média de 26,2 anos, receberam exame clínico periodontal através do Índice Periodontal Comunitário de Necessidade de Tratamento (CPITN) (OMS) e exame microbiológico para deteç̧ão dos níveis de $T$. denticola, $P$. gingivalis e $B$. forsythus pelo teste BANA. Através de registros médicos pós-parto, obtiveram-se informações sobre história médica, uso de tabaco, consumo de álcool, ocorrência de parto prematuro ou baixo peso ao nascer, história de parto prematuro prévio, nascimento de baixo peso prévio ou aborto espontâneo e início dos cuidados pré-natais. Embora as puérperas com ocorrência do parto a pré-termo e nascimentos de baixo peso exibissem "scores" médios (CPITN) mais altos do que as puérperas com ocorrência do parto no termo, as diferenças não foram significativas. Puérperas com história de parto prematuro prévio ou nascimento prévio de baixo peso apresentavam números significativamente mais altos de dentes com resultado positivo no teste BANA (infecções anaeróbicas periodontais) do que as puérperas sem resultados adversos na gravidez.

Em estudo desenvolvido em Porto Alegre (Brasil) por LOURO et al. ${ }^{58}$ (2001), a influência da doença periodontal na gravidez sobre o peso de nascimento dos recém-nascidos foi investigada. Com o auxílio do Índice de Extensão e 
Severidade da Doença Periodontal (CARLOS et al. ${ }^{12} 1986$ ), a condição periodontal de 26 puérperas, 13 com peso do bebê ao nascer inferior a 2.500 gramas e 13 cujos bebês nasceram com 2.500 gramas ou mais, foi avaliada. $\mathrm{O}$ emprego da análise multivariada mostrou uma forte associação entre a severidade da doença periodontal e o baixo peso ao nascer após ajuste para diferentes fatores de risco (fumo, estatura materna, bacteriủria e hipertensão prévia).

NOACK et al. ${ }^{79}$ (2002), em estudo desenvolvido na Alemanha, analisaram a condição periodontal (avaliação da profundidade de sondagem, nível de inserção clínico e presença de sangramento à sondagem), a presença de patógenos periodontopatogênicos na placa bacteriana subgengival ( $A$. actinomycetemcomitans, $P$. intermedia, $P$. gingivalis e $B$. forsythus) e os niveis de $\mathbb{L}-1 \alpha$ no fluido crevicular gengival de 101 puérperas. Estas foram divididas em três grupos: 1) com ocorrência do parto a pré-termo e peso do bebê ao nascer inferior a 2.500 gramas; 2) com ocorrência do parto no termo e peso de bebê ao nascer maior ou igual a 2.500 gramas, mas com desencadeamento de trabalho de parto prematuro durante o período gestacional; 3) sem a presença de trabalho de parto prematuro e resultado desfavorável na gestação. Os autores não encontraram diferenças significativas entre os grupos em relação aos diversos parâmetros avaliados. Utilizando um modelo de regressão logística e controlando os outros fatores de risco, a presença da periodontite não demonstrou exercer risco para o nascer prematuro de baixo peso.

Através do desenvolvimento de estudo longitudinal, MOORE et al ${ }^{74}$ (2002a) investigaram o papel da doença periodontal frente a nascimento prematuro e/ou baixo peso ao nascer em Londres (Inglaterra). Cerca de 3.000 gestantes recrutadas entre a $10^{a}$ e $15^{a}$ semana gestacional foram submetidas a um exame 
periodontal e ao preenchimento de um questionário acerca da ocorrência de possiveis fatores de risco obstétricos. Apesar de a relação entre o resultado da gestação e os fatores estabelecidos de risco obstétricos ter sido confirmada através da análise de regressão, não foram constatadas relações significativas entre a severidade da doença periodontal, o nascimento prematuro e/ou baixo peso ao nascer.

Das 3.186 gestantes selecionadas (coorte) por MOORE et al. ${ }^{75}(2002 \mathrm{~b})$ para acompanhamento longitudinal dos efeitos da infecção periodontal sobre o desenvolvimento da gestação, 167 gestantes com ocorrência de pelo menos cinco sítios com profundidade de sondagem de $5 \mathrm{~mm}$ ou mais e três sítios com pelo menos $3 \mathrm{~mm}$ de perda de inserção foram recrutadas. Destas, 85 foram encaminhadas para tratamento periodontal, enquanto as demais foram apenas aconselhadas a visitar seus próprios dentistas. Embora 55 gestantes do grupo que foi encaminhado para tratamento periodontal tenham recebido algum tipo de intervenção terapêutica, nenhuma diferença na taxa de resultados adversos da gestação entre as gestantes tratadas periodontalmente e as gestantes que compunham a população de estudo pôde ser observada. Entretanto, dentre as gestantes encaminhadas para a realização de tratamento periodontal, as que não realizaram nenhum tipo de intervenção terapêutica periodontal tiveram maiores taxas tanto de nascimentos prematuros, bem como bebês com muito baixo peso e ocorrência de abortos. A realização de tratamento periodontal na gestação pode ter um efeito protetor contra resultados adversos na gravidez.

Em estudo realizado no Rio de Janeiro (Brasil), MOLITERNO et al. ${ }^{73}$ (2002) avaliaram 100 puérperas distribuídas em dois grupos: grupo caso, cuja ocorrência do parto foi a pré-termo e o peso de nascimento do bebê, inferior a 2.500 
gramas; e grupo controle, com nascimento no termo e peso do bebê maior do que 2.500 gramas. Foram consideradas doentes periodontais as puérperas que apresentavam pelo menos quatro sítios com perda de inserção periodontal maior que $4 \mathrm{~mm}$. Através do teste $x^{2}$, uma associação estatisticamente significativa foi observada entre a ocorrência da doença periodontal e o nascimento prematuro de baixo peso.

A magnitude dos efeitos da infecção periodontal, bem como de sua progressão durante o período gestacional, sobre a prematuridade e o baixo peso ao nascer, demonstrada em diferentes estudos populacionais, sugere que a doença periodontal é um fator de risco significante e pode ter um grande impacto nas taxas de complicações obstétricas, assim como o fumo, o álcool ou as infeç̧ões do trato genitourinário (OFFENBACHER et al. ${ }^{89}$ 2001).

É possível que a infecção periodontal, representada por um desafio anaeróbico Gram negativo, possa servir como um reservatório crônico para transferência de bactérias ou produtos bacterianos, tais como LPS, para a unidade feto-placentária. No entanto, embora patógenos periodontais sejam considerados necessários, não são suficientes para a ocorrência da doença periodontal. O papel da resposta inflamatória do hospedeiro parece ser um determinante crítico da susceptibilidade e severidade da doença, pois diversos estudos têm demonstrado que pacientes de risco para doença periodontal severa têm um quadro inflamatório diferente dos pacientes de baixo risco periodontal. Assim, a associação entre doença periodontal e parto prematuro de baixo peso pode ser reflexo de uma característica inflamatória particular do hospedeiro, colocando o individuo em risco para ambas as condições (OFFENBACHER et al. ${ }^{88} 1998 \mathrm{~b}$ ). Também é possível que citocinas, tais como PGE2 e FNT $\alpha$, produzidas pelo periodonto infectado, alcancem a placenta através da circulação sanguínea (OFFENBACHER et al. ${ }^{87,88} 1998 \mathrm{a}, \mathrm{b}$ ). 


\section{OBJETIVOS}

A presente pesquisa, desenvolvida a partir de dados primários, tem como objetivos:

1. descrever a condição periodontal em um grupo de puérperas com ocorrência do parto no termo com peso do bebê ao nascer maior ou igual a 2.500 gramas e a pré-termo com peso do bebê ao nascer inferior a 2.500 gramas, estimando os níveis de severidade e extensão da doença periodontal nos dois grupos;

2. verificar se a presença da doença periodontal materna está associada à ocorrência do nascer prematuro e ao baixo peso ao nascer;

3. verificar se a doença periodontal materna é fator de risco ao parto pré-termo e ao baixo peso ao nascer. 


\section{MATERIAL E MÉTODO}

\subsection{População de estudo}

\subsubsection{Seleção de pacientes}

Esta pesquisa (estudo de caso-controle do tipo prospectivo, com formação de grupos não pareados) (FORATTIN ${ }^{30}$ 1976; ROUQUAYROL ${ }^{104}$ 1983) foi desenvolvida no município de São Paulo, SP, Brasil, durante periodos habituais de internação hospitalar pós-parto (48 a 72 horas), entre agosto de 2000 e setembro de 2001, nas seguintes unidades hospitalares: a) Hospital São Paulo; b) Hospital Municipal Vereador José Storópoli (Hospital Vila Maria); e c) Unidade de Gestão Assistencial II-Hospital Ipiranga.

As unidades "a" e "b" são hospitais-escola da Universidade Federal de São Paulo - Escola Paulista de Medicina (UNIFESP-EPM) (anexo 7) e a unidade "c" um hospital Estadual. Todas apresentam as mesmas caracteristicas enquanto ambiente universitário, são hospitais de referência para gestação de elevado risco e possuem normas de conduta muito semelhantes no atendimento prestado às gestantes e puérperas pelo Serviço de Ginecologia-Obstetricia.

A população de estudo foi constituida por 174 puérperas, de parto vaginal ou cesariana, pertencentes a estratos sociais semelhantes, assistidas gratuitamente pelo Sistema Único de Saúde (SUS), sendo 103 com ocorrência do parto no termo e peso do bebê ao nascer maior ou igual a 2.500 gramas e 71 com parto a pré-termo e peso do bebê ao nascer inferior a 2.500 gramas.

O parto prematuro foi caracterizado por ocorrência anterior à $37^{\mathrm{a}}$ semana completa de gestação, tendo-se como base a data do primeiro dia da última 
menstruação confiável (DUM), sendo decorrente de ruptura prematura de membrana ou de trabalho de parto prematuro (TPP) propriamente dito, segundo a Organização Mundial de Saúde (OMS) (1972).

Todo concepto nascido com menos de 2.500 gramas foi considerado como um recém-nato de baixo peso ao nascer, de acordo com a Organização Mundial de Saúde (OMS) (1972).

Foram pré-selecionadas puérperas com ocorrência do parto a pré-termo conforme a idade gestacional do concepto registrada no prontuário hospitalar, tendo-se como referência a data do primeiro dia da última menstruação confiável, a qual foi confirmada, em caso de dúvida, por ultra-sonografia obstétrica precoce e índices neonatais (New Balaard ${ }^{6}$ ou Capurro ${ }^{62}$ (anexo 2). Essas pacientes foram submetidas a uma entrevista inicial (anexo 1), e, com base em suas histórias médicas e obstétricas da época e pregressa, foram eleitas para o estudo.

Para cada puérpera com ocorrência do parto a pré-termo selecionada para o estudo, uma puérpera com ocorrência do parto no termo era pré-selecionada para a entrevista inicial (anexo 1). O nascimento a termo deveria ter acontecido imediatamente após o nascer prematuro eleito para o estudo, segundo registros do prontuário hospitalar.

A seleção das puérperas para formação dos grupos caso-controle, exceto pela presença ou ausência do agravo (doença periodontal) em estudo, respeitou o princípio de similitude em relação a fatores que pudessem exercer alguma influência, havendo uma constância no perfil socioeconômico-cultural, representando uma amostra do conjunto total de puérperas selecionáveis nas unidades hospitalares (ALMEIDA FILHO e ROUQUAYROL ${ }^{1}$ 1992; RÊGO ${ }^{92} 2001$ ). 
Duzentos e sessenta puérperas foram pré-selecionadas, não sendo incluidas no estudo as que apresentavam características individuais e/ou intercorrências clinicas, ginecológicas ou obstétricas condicionantes do parto pré-termo, tais como:

a) malformação fetal maior;

b) gestação múltipla;

c) malformação uterina;

d) intercorrências clínicas e/ou obstétricas graves, que obrigaram a interrupção eletiva da gestação pelo obstetra para tentar salvaguardar a vida da mãe e/ou do concepto;

e) diagnóstico de insuficiência ístmica-cervical durante a gestação, recente ou passada, comprovada por história típica e/ou provas interpartais;

f) óbito fetal;

g) descolamento prematuro da placenta;

h) problemas cardíacos e/ou reumatismo infeccioso;

i) HIV positivo;

j) Lupus eritematoso sistêmico;

k) HPV-papiloma vírus humano;

1) Isoimunização $\mathrm{Rh}$;

m) idade materna inferior a 17 anos e superior a 35 anos de idade (idades extremas da vida reprodutiva).

Para complementar as informações prestadas pelas puérperas, foram realizadas consultas (anexo 2) ao prontuário hospitalar após o término das entrevistas iniciais, quando necessário. 
Às puérperas selecionadas para o estudo foi salientada a importância deste trabalho e solicitado o seu consentimento de participação na pesquisa (anexo 3), conforme detalhado no item "Aspectos Éticos" deste capitulo.

\subsubsection{Definição de caso/controle}

\section{Caso}

O grupo caso foi constituído por puérperas cujos partos ocorreram a pré-termo e o bebê ao nascer apresentava peso inferior a 2.500 gramas (grupo pré-termo).

\section{Controle}

O grupo controle foi constituído por puérperas cujos partos ocorreram no termo com peso do bebê ao nascer maior ou igual a 2.500 gramas (grupo termo).

\subsection{Variáveis}

No intuito de melhor caracterizar a população de estudo, foram consideradas as seguintes variáveis, conforme códigos e categorias:

\section{A) Características individuais}

1. Estado civil:

0 - casada, vida conjugal

1 - solteira, divorciada, viúva

2 - sem informação

2. Idade materna (expressa em anos completos na data da parturição):

$0-$ de 17 a 20 anos

1 - de 21 a 25 anos 
2 - de 26 a 30 anos

3 - de 31 a 35 anos

3. Pré-natal (ocorrência de visitas ao obstetra para cuidados pré-natais):

0 - fez pré-natal

1 - não fez pré-natal

4. Local de realização dos cuidados pré-natais:

0 - não fez pré-natal

1 - rede oficial

2 - serviço universitário

3-convênio/particular

4 - sem informação

5. Número de visitas pré-natais:

0 - não fez pré-natal

1 - de uma a sete consultas

2 - oito consultas ou mais

3 - sem informação

6. Início dos cuidados pré-natais:

0 - não fez pré-natal

1-primeiro trimestre

2- segundo trimestre

3 - terceiro trimestre

4-sem informação 
7. Índice de massa corpórea:

$0-$ baixo peso

1 - normalidade

2 - sobrepeso

3 - obesidade

4 - sem informação

8. Tipo de parturição atual:

0 - cesariana

1 - via vaginal

9. Sexo do recém-nato:

0 - feminino

1 - masculino

10. Número de cigarros consumidos por dia antes da última gestação:

0 - não fuma

1. - fuma de 1 a 10 cigarros por dia

2 - fuma de 11 a 20 cigarros por dia

3 - fuma 21 ou mais cigarros por dia

4 - sem informação

11. Número de cigarros consumidos por dia durante a última gestação:

0 - não fuma

1 - fuma de 1 a 10 cigarros por dia

2 - fuma 11 ou mais cigarros por dia

3 - sem informação 
12. Tempo estimado de consumo de tabaco:

0 - não fuma

1 - fuma há menos de 10 anos

2 - fuma há 10 anos ou mais

3 - sem informação

13. Uso de drogas ilícitas:

$0-$ nunca usou

1 - usa ou já usou

14. Tipo de droga ilícita consumida,

15. Uso de álcool,

16. Freqüência semanal de ingestão de bebidas alcoólicas,

17. Tempo estimado de consumo de álcool,

As variáveis 15,16 e 17 não foram codificadas pelo fato de nenhum caso de etilismo ter sido encontrado.

\section{B) História reprodutiva}

18. Número de gestações (quantas vezes a puérpera esteve grávida, incluindo a última gestação):

0 - primigesta

1 - multigesta

2 - grande multigesta

3 - sem informação 
19. Paridade (número de partos concluídos anteriores à atual parturição):

0 - nulipara

1 - primípara

2 - multípara

3 - grande multípara

4 - sem informação

20. Número de partos prematuros prévios:

0 - não

$1-\operatorname{sim}$

2 - sem informação

21. Número de abortos prévios:

$0-$ não

$1-\operatorname{sim}$

2 - sem informação

\section{C) Intercorrências clínicas}

22. Diabetes mellitus;

$0-$ não

$1-\operatorname{sim}$

23. Hipertensão:

$0-$ não

$1-\operatorname{sim}$ 
24. Infecções do trato genitourinário:

$$
\begin{aligned}
& 0 \text { - não } \\
& 1-\operatorname{sim} \\
& 2 \text { - sem informação }
\end{aligned}
$$

25. Doença periodontal:

$$
\begin{aligned}
& 0-\text { não } \\
& 1-\operatorname{sim}
\end{aligned}
$$

26. Ocorrência de tratamento periodontal anteriormente à última gestação:

$0-$ não

$1-\operatorname{sim}$

27. Ocorrência de tratamento periodontal durante o último período gestacional:

$0-$ não

$1-\operatorname{sim}$

28. Tipo de tratamento periodontal realizado:

$0-$ não fez

1 - bochechos

2 - limpeza dental

3 - raspagem

4 - cirurgia

29. Nível de escolaridade materna:

0 - analfabeta

$1-1^{\circ}$ grau completo/incompleto 
$2-2^{\circ}$ grau completo/incompleto

3 - nível superior

Dentre os aspectos sócio-demográficos, foram coletadas informações a respeito do tipo de moradia das puérperas, considerando o tipo de propriedade do imóvel, a característica do espaço urbano e os materiais de construção predominantes no imóvel. Dados sobre a ocupação das puérperas também foram coletados.

\subsection{Procedimentos metodológicos}

\subsubsection{Coleta dos dados}

Para a coleta de informações a respeito do histórico médico e obstétrico (da época e pregresso) de cada puérpera, com o intuito de selecioná-las previamente para o estudo, foram realizadas:

- entrevistas, denominadas "iniciais", desenvolvidas na forma de um questionário registrado numa ficha (anexo 1) elaborada para esse fim;

- consultas aos registros do prontuário hospitalar. Os dados obtidos foram anotados em uma ficha (anexo 2) semelhante à elaborada para a realização da entrevista inicial.

Uma abordagem mais abrangente a respeito de características individuais, história obstétrica (da época e pregressa), hábitos e aspectos sócio-demográficos de cada puérpera participante do estudo foi realizada através de:

- entrevistas, denominadas "avançadas", aplicadas de acordo com questionário previamente elaborado, registrado em ficha própria (anexo 4);

- consultas aos registros do prontuário hospitalar, a fim de complementar ou confirmar as informações prestadas pelas puérperas na entrevista avançada. Os 
dados foram anotados em uma ficha (anexo 5) semelhante à utilizada durante a realização da pesquisa avançada.

Dados a respeito da condição periodontal de cada puérpera participante da pesquisa foram obtidos através da realização de:

- entrevista, acima denominada como avançada (anexo 4);

- exame clínico periodontal, registrado numa ficha clínica específica, denominada "ficha para registro periodontal" (anexo 6).

Previamente ao início da coleta dos dados, a aplicabilidade das fichas (anexos 1, 4 e 6) no desenvolvimento das entrevistas inicial e avançada e na realização do exame clínico periodontal foi testada em dez puérperas pré-selecionadas para o estudo. O tempo dispendido para execução de cada procedimento e para o preenchimento das respectivas fichas, bem como a objetividade e a clareza das perguntas dos questionários dos anexos 1 e 4 foram avaliados. Com base nesse pré-teste, os instrumentos sofreram pequenos ajustes e assumiram a forma definitiva utilizada na investigação.

\subsubsection{Execução da entrevista}

A realização das entrevistas de cada puérpera ficou sob a responsabilidade de um único examinador - o próprio pesquisador.

As entrevistas inicial e avançada, realizadas no próprio leito hospitalar, com duração aproximada de dez e trinta minutos, respectivamente, foram desenvolvidas por intermédio de perguntas feitas verbalmente pelo examinador com base nos questionários (anexos 1 e 4). As respostas dadas verbalmente pelas puérperas foram anotadas nas fichas pelo próprio examinador. 
Para análise da presença de fatores que pudessem embargar a participação da puérpera no estudo, foram realizadas perguntas objetivas na entrevista inicial (anexo 1), as quais requeriam respostas do tipo "sim" e "não". Quando a parturiente não sabia a resposta, ficava em dúvida ou preferia omiti-la, o examinador preenchia o campo "ns/nr" (não sabe/não respondeu), indicando assim que havia uma resposta, porém não explícita. Ocorrendo esse fato, o examinador, após o término do preenchimento do anexo 1, recorria às informações contidas no prontuário hospitalar, para completar os dados faltantes, utilizando para anotação desses dados a ficha para consulta inicial ao prontuário hospitalar (anexo 2). Se, após consulta aos registros do prontuário hospitalar, alguma pergunta ainda ficasse sem resposta, o campo "s/inf."(sem informação) era então preenchido, indicando assim a ausência de dados.

Entre o desenvolvimento das entrevistas inicial e avançada, decorria um pequeno intervalo de tempo para que o examinador pudesse: completar, quando necessário, as informações prestadas pelas parturientes através de consultas ao prontuário hospitalar; analisar as informações obtidas; fazer a seleção das puérperas; explicar a elas a importância do estudo, os objetivos e as etapas da pesquisa; e obter seu consentimento.

A entrevista avançada (anexo 4), aplicada às puérperas selecionadas para o estudo e que tinham assinado o termo de consentimento para participação na pesquisa (anexo 3), foi desenvolvida de maneira análoga à entrevista inicial, ou seja, com perguntas claras, objetivas, que requeriam, em sua quase totalidade, respostas simples do tipo "sim" e "não" sobre o histórico obstétrico da parturiente e seus hábitos. Quando a puérpera não sabia a resposta, ficava em dúvida ou preferia omitila, o examinador preenchia o campo "ns/nr", para, posteriormente, recorrer aos 
registros do prontuário hospitalar. Caso não obtivesse resposta após consulta aos dados do prontuário, o campo "s/inf." era então preenchido.

Para o campo "estado civil", inicialmente foram consideradas as seguintes situações conjugais: casada, vida conjugal, solteira, divorciada ou viúva. Posteriormente foram reagrupadas em duas categorias de acordo com a ocorrência de um parceiro constante: casada ou tem vida conjugal e outro grupo com outras situações conjugais.

O campo "idade materna" era preenchido de acordo com a idade da puérpera em anos completos até a data da parturição.

No campo correspondente ao local de realização dos cuidados pré-natais, foram consideradas as seguintes situações: 1) rede oficial: realização de pré-natal em posto de saúde e/ou rede hospitalar municipal, estadual ou federal, cujo atendimento foi feito pelo SUS; 2) serviço universitário: realização de pré-natal em local oficial de responsabilidade de uma faculdade de Medicina; 3) convênio/particular.

Para o preenchimento do campo "número de visitas realizadas no pré-natal”, o examinador classificava as respostas em duas categorias - de uma a sete visitas e oito visitas ou mais -, de acordo com as recomendações do Manual Técnico de Assistência Pré-natal do Ministério da Saúde ${ }^{69}$ (2000).

O preenchimento do campo correspondente ao trimestre no qual a parturiente iniciava seus cuidados pré-natais era feito pelo examinador após o término da entrevista. Este considerava a época gestacional relatada pela puérpera como início das visitas ao obstetra para realização do pré-natal, informação registrada na ficha de pesquisa avançada no campo "Início". 
No campo IMC (Indice de Massa Corpórea de Quetelet), coube ao examinador, posteriormente à entrevista, calcular o valor do índice, definido para cada puérpera como a razão entre o peso pré-gravídico (em quilograma) pela altura (em metro) elevada ao quadrado.

A classificação de Quetelet para o IMC é:

- $\quad \mathrm{MMC}<16$ : anorexia nervosa;

- $\quad \mathrm{MC} \geq 16$ e $<19$ : baixo peso;

- $\quad \mathrm{IMC} \geq 19$ e IMC < 25: faixa de normalidade. $\mathrm{O}$ ideal é 21 ;

- $\quad \mathrm{IMC} \geq 25$ e $\mathrm{IMC} \leq 30$ : sobrepeso;

- $\mathrm{IMC}>30$ e $\mathrm{IMC} \leq 40$ : obesidade;

- $\quad$ MC > 40: obesidade mórbida.

Como tipo de parturição atual, foram considerados os partos via vaginal ou cesariana.

A variável "álcool” foi estimada através da avaliação da freqüência do consumo de bebidas alcoólicas. Uma puérpera seria considerada etilista caso consumisse álcool todos os dias da semana, independentemente do tempo estimado no consumo.

Dentro da história reprodutiva, coube ao examinador preencher, após o término da entrevista, a partir de informações prestadas pelas puérperas e anotadas na ficha, o campo correspondente à classificação do número de gestações, incluindo a última. Considerou-se como primigesta a puérpera em sua $1^{\text {a }}$ gestação, multigesta, as puérperas entre a $2^{\mathrm{a}}$ e $4^{\mathrm{a}}$ gestação, e grandes multigestas aquelas com cinco gestações ou mais. 
O campo pertinente ao número de partos concluídos, excluindo o último, também foi preenchido pelo examinador ao final da entrevista, de acordo com as informações dadas pelas parturientes. Foram consideradas nulíparas as puérperas que nunca tiveram parturição, primiparas, aquelas que tiveram um único parto, multiparas, as que já tinham tido de dois a quatro partos, e grandes multíparas aquelas com cinco partos ou mais.

Ao final da entrevista, foi perguntado à puérpera o tipo de tratamento periodontal realizado caso ela tivesse relatado história recente ou passada de terapia periodontal. Esse dado foi anotado na ficha de pesquisa avançada conforme seu próprio relato.

\subsubsection{Execução da consulta ao prontuário hospitalar}

As consultas aos dados registrados no prontuário hospitalar foram realizadas pelo próprio entrevistador (o pesquisador) logo após o término da realização das entrevistas inicial e avançada.

Os dados obtidos eram anotados nas fichas para consulta inicial e avançada ao prontuário hospitalar (anexos 2 e 5), similares às fichas de pesquisa inicial e avançada (anexos 1 e 4), não tendo sido necessário ao examinador dispor mais do que dez e vinte minutos, respectivamente, para tal procedimento.

\subsubsection{Execução do exame clínico periodontal}

Finalizada a entrevista avançada, iniciava-se o exame clínico periodontal, conforme a descrição a seguir. 


\subsubsection{Pessoal e organização}

O exame clínico periodontal foi realizado no próprio leito hospitalar, com duração aproximada de vinte minutos, em uma posição confortável à puérpera e com o aproveitamento, sempre que possível, de fontes de luz naturais. Nessas condições, foram inevitáveis as variações na iluminação, mas em nenhum caso tais variações foram de tal ordem que impedissem a realização do exame.

Para a realização do exame clínico periodontal, foi necessário o auxilio de um anotador capaz de registrar com exatidão, na ficha para registro periodontal (anexo 6), os dados ditados pelo examinador.

Embora o anotador estivesse familiarizado com o sistema de anotação, previamente ao início do estudo foram dadas a ele, pelo próprio examinador, instruções especiais e treinamento específico, desenvolvido através do registro de vários dados obtidos em exames preliminares. Esse treinamento foi feito em clínica odontológica, fora do ambiente hospitalar.

Durante a realização do exame, o anotador ficava em posição frontal ao examinador, de modo a ouvir facilmente o seu comando. Ao final do exame de cada quadrante, o examinador falava a palavra "cheque", possibilitando ao anotador verificar a similitude de sua anotação.

Ao examinador coube a responsabilidade de examinar cada parturiente de maneira padronizada, minimizando assim possiveis variações na interpretação dos achados clínicos. 


\subsubsection{Instrumental e material}

Doze jogos de instrumentos, listados a seguir, foram providenciados para se evitar a interrupção de exames por falta de instrumentos esterilizados. Também estão presentes nesta lista suplementos necessários à execução do exame clínico periodontal.

Os instrumentos e suplementos são os seguintes:

- espelho bucal plano;

- pinça clínica;

- sonda Glikman $26 \mathrm{G}$ (periodontal);

- gorro;

- máscara;

- luva de procedimento;

- óculos de proteção;

- espelho de toucador com cabo longo e tamanho médio;

- cubeta de aço inoxidável;

- gaze esterilizada;

- papel toalha;

- avental de pano;

- detergente líquido;

- escova para limpeza do instrumental;

- álcool a 70\%;

- caneta;

- lápis e borracha;

- fichas de pesquisa e de registro periodontal. 
Espelho bucal plano, pinça clínica, sonda Glikman 26G, gaze e cubeta foram esterilizados em autoclave a uma temperatura de 134 a $138^{\circ} \mathrm{C}$, durante 3 minutos, sob uma pressão de duas atmosferas, no consultório odontológico do examinador. Suplementos tais como gorro, máscara e luva de procedimento eram descartados após o exame de cada puérpera. Os óculos de proteção eram desinfectados após a realização de cada exame clínico com álcool a $70 \%$ embebido em gaze, sendo esse procedimento repetido por três vezes consecutivas (COTTONE et al. ${ }^{19}$ (1991).

\subsubsection{Condição periodontal}

Para a avaliação da presença da doença periodontal, expressa pela perda dos tecidos periodontais de sustentação, foi realizada a sondagem do nível de inserção periodontal, denominada sondagem do nível de inserção clínico, ou seja, a medição da distância, em milímetros, da junção-cemento-esmalte até a posição em que a ponta de uma sonda periodontal graduada inserida no sulco gengival ou bolsa periodontal encontra resistência (American Academy of Periodontology-AAP-1992) (Figura 2).

Figura 2 - Sondagem clínica para avaliação do nível de inserção periodontal

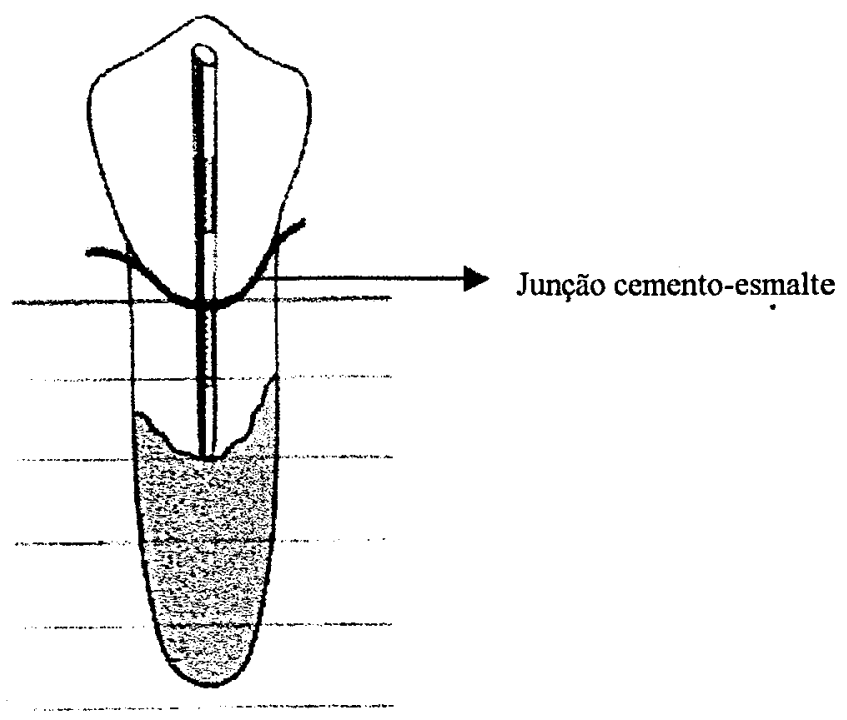


Assim, para se avaliar clinicamente a ocorrência da perda dos tecidos periodontais de sustentação, foi inserida uma sonda periodontal graduada com pressão aproximada de 25 gramas no interior do sulco gengival ou bolsa periodontal, em dois pontos ou sítios de cada elemento dental (faces médio-vestibular e mésio-vestibular) presente nos quadrantes superior direito e inferior esquerdo, excetuando-se os terceiros molares. $O$ valor obtido foi a medida da distância entre a porção mais apical sondável e a junção-cemento-esmalte, em milímetros.

Foram consideradas doentes periodontais as puérperas que apresentavam pelo menos dois sítios, dentre os examinados, com nível de inserção periodontal de dois milimetros ou mais.

Pelo fato de a escolha de pelo menos dois sítios, dentre os examinados, com perda de inserção periodontal de dois milímetros ou mais ter sido feita de modo arbitrário, optou-se por verificar a possibilidade de associação entre a presença da doença periodontal e a ocorrência do parto prematuro de baixo peso ao nascer quando níveis de exposição diferentes à doença periodontal fossem estabelecidos.

Três novos limiares foram arbitrariamente escolhidos, sendo considerados os seguintes níveis de exposição à doença periodontal: a) perda de inserção periodontal de dois milímetros ou mais em pelo menos um sítio, dentre os examinados; b) perda de inserção periodontal de dois milimetros ou mais afetando três ou mais sitios, dentre os examinados; c) mesma severidade de doença, porém com maior extensão, ou seja, pelo menos dois milímetros de perda de inserção periodontal em pelo menos quatro sítios, dentre os examinados. 
Para a avaliação do nível de inserção periodontal médio de cada puérpera, as medidas em milimetros, obtidas através da sondagem do nível de inserção clínico, foram somadas e divididas pelo número de sítios examinados.

Para a avaliação do efeito cumulativo da doença periodontal destrutiva, foi utilizado o Índice de Extensão e Severidade da Doença Periodontal ou ESI (CARLOS et al. ${ }^{12}$ 1986).

Segundo Carlos et al. ${ }^{12}$ (1986), "O indice de extensão e severidade (ESI) é uma tentativa para preservar a quantidade máxima de informação de um exame clinico coerente com a necessidade de se obter um grau razoável de redução de dados.

O indice é calculado para resumir conjuntamente a extensão e a severidade média de doença dentro do grupo que está sendo estudado (...)

Os dados armazenados nos estudos epidemiológicos da doença periodontal podem ser considerados como um vetor de medida $[x 1, x 2, x 3, \ldots, x N]$, onde xi é uma medida em milimetro do nível de inserção periodontal , ou da profundidade da bolsa periodontal ou, em alguns estudos, da perda óssea alveolar conforme estimada em radiografias, e $N$ é o número máximo de sitios diagnosticáveis para cada individuo

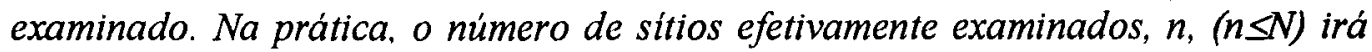
variar geralmente entre os individuos por causa dos dentes perdidos ou áreas não diagnosticáveis.

No ESI as medidas são estimativas do nível de inserção dos tecidos periodontais, determinadas pela subtração da distância de sondagem (mm) da margem gengival à junção-cemento-esmalte (jce), da distância medida da margem gengival ao fundo do sulco. Quando a margem gengival está localizada apicalmente 
à junção-cemento-esmalte a primeira medida é registrada como um valor negativo (Ramfjord. 1974).

Para avaliar a extensão da doença. alguns critérios devem ser aplicados para diferenciar entre medidas "normais" e aquelas indicativas de patologia. Os autores têm adotado a regra arbitrária e conservadora que um sitio é considerado doente somente quando a perda de inserção excede a $1 \mathrm{~mm}$. Portanto um vetor adicional [di] é produzido, onde

$$
d i=1 \text { se } x i>1 \text { e } d i=0 \text { se } x i \leq 1 \text {. }
$$

$A$ extensão da doença, E, é simplesmente expressa como a porcentagem daqueles sitios efetivamente examinados que exibiram doença

$$
E=\underset{\substack{n \\ i=1}}{n} \text { dix } 100) / n
$$

a qual corrige a variação no número de sitios com risco quando $n<N$.

A severidade da doença, $S$, é expressa como a perda média de inserção, além de $1 \mathrm{~mm}$, para sitios onde $d i=1$,

$$
S=\sum_{i=1}^{n}[d i(x i-1)] /, \Sigma d i
$$

O indice de extensão e severidade é então escrito

$$
E S I=(E, S)
$$

onde $E$ é arrredondado para o número inteiro mais próximo. O ESI para uma população ou grupo é a média dos resultados individuais de E e $S(\ldots)$

Os escores usados para calcular o ESI são obtidos do exame de somente metade da boca de cada individuo. O ESI estima o nivel de inserção de medidas de sondagem de 14 sitios em um quadrante da maxila e em 14 do quadrante mandibular 
contralateral (quadrante superior direito e inferior esquerdo). Pouca informação é perdida pelo uso do exame de metade da boca, pelo fato do nivel de inserção tender a ser bilateralmente simétrico. mesmo entre individuos mais jovens que têm baixos niveis de doença.

A seleção dos sitios médio-vestibular e mésio-vestibular para estimativa do nivel de inserção foi baseada, em certo modo, na facilidade de acesso e visualização dessas áreas.

Este indice não tenciona o diagnóstico clinico ou descrições de individuos, mas pode dar informações sugestivas acerca de padrões contrastantes de doença entre diferentes populações ou grupos de uma população".

CARLOS et al. ${ }^{12}$ (1986) propuseram um sistema de índice bivariável para registrar a perda do tecido periodontal de sustentação, denominado Índice de Extensão e Severidade da Doença Periodontal ou ESI. Formado por dois componentes: a Extensão, que descreve a proporção de sítios examinados de um indivíduo apresentando sinais de doença periodontal destrutiva; e a Severidade, que expressa como um valor médio a quantidade de perda de tecido periodontal de inserção nos sítios afetados. Foi planejado para avaliar o efeito cumulativo da doença periodontal destrutiva, em vez da presença da doença periodontal em si.

Um limiar de perda de inserção maior que um milímetro foi estabelecido como critério para que um sítio pudesse ser considerado doente. Apesar de arbitrária, a introdução de um valor como limiar tem duplo propósito: distingue prontamente a parte da dentição afetada pela doença em níveis que excedem ao erro inerente na medição clínica da perda de inserção e evita que as áreas do dente que não foram afetadas contribuam para o valor médio do índice. 
Para medir Extensão: $E=(\Sigma d i .100) / n$, onde:

$d i=0$, se o nível de inserção periodontal for igual a 1 milimetro, e $d i=1$, se o nivel de inserção periodontal for maior que 1 milimetro.

Portanto, somando os $d i$, teremos o número de sítios com profundidade $>1$ milimetro, dividido pelo número de sitios examinados, vezes 100 . Isso significa o percentual de sítios com profundidade $>1$ milímetro, ou seja, percentual de sítios examinados com doença periodontal.

Para medir Severidade: $S=\Sigma[d i(x i-1)] / \Sigma d i$, onde:

$x i$ será o valor em milimetro do nivel de inserção periodontal em cada sítio.

Como só se considera $d i=I$ nos sitios em que houver doença, multiplica-se 1 pela diferença do valor do nível de inserção, em milímetro, menos 1 e divide-se pelo número de sítios doentes $(\Sigma$ di=1). O nível de inserção periodontal médio, em milímetro, dos sítios afetados é expresso por $S$, só considerando a parte que ultrapassa $1 \mathrm{~mm}$

\subsubsection{Análise dos dados}

\subsubsection{Avaliação dos dados médicos e obstétricos}

Embora todos os dados coletados na entrevista inicial tenham sido avaliados pelo pesquisador com vistas a uma criteriosa seleção das puérperas que participariam do estudo, outra avaliação desses dados foi realizada ao final da coleta, antes de se organizar o banco de dados e iniciar a análise estatística. 
Com o auxilio de um médico obstetra, todos os dados coletados foram então novamente avaliados para certificação da ausência de fatores de exclusão dentre as puérperas selecionadas.

O estabelecimento de um encontro entre médico obstetra-pesquisador também possibilitou o esclarecimento de dúvidas a respeito da história médica e obstétrica de cada puérpera participante do estudo, bem como a compreensão de determinados aspectos clínicos.

Como a premissa deste trabalho é a ocorrência da doença periodontal materna como possivel fator de risco ao nascimento prematuro e ao baixo peso ao nascer, cabe destacar que embora conhecidos fatores de risco médicos e obstétricos, bem como hábitos, associados ao nascer prematuro e de baixo peso também tenham sido investigados, tais como, consumo de álcool, uso de tabaco ou outras drogas, cuidados pré-natais, paridade, infeç̧ões genitourinárias, prematuridades prévias e outros, esses dados não foram abordados no capitulo "discussão". Foram apenas apresentados em "resultados" com o intuito de melhor caracterizar a população de estudo.

\subsubsection{Organização do banco de dados}

A coleta dos dados durante a realização das entrevistas inicial e avançada e da consulta complementar ao prontuário hospitalar foi desenvolvida mediante 0 preenchimento manual das respectivas fichas.

A organização e a análise dos dados foram feitas com o auxílio do programa computacional EPI INFO, versão 6.04 (DEAN et al. ${ }^{27}$ 1997), pelo qual os dados 
foram digitados e tabulados para, posteriormente, serem codificados por categorias dentro de cada variàvel.

\subsubsection{Análise estatística}

Os dados foram apresentados inicialmente através de estatistica descritiva com tabelas apresentando números absolutos e percentuais.

Foi aplicado o teste $x^{2}$, ou teste exato de Fischer, para estudar a associação entre cada variável e os grupos caso e controle. Toda associação foi testada no nível de significância de $5 \%$.

Um algoritmo foi desenvolvido para cálculo do Índice de Extensão e Severidade da Doença Periodontal (CARLOS et al. ${ }^{12}$ 1986), com aplicação no EPI INFO (DEAN et al. ${ }^{27}$ 1997), para o processamento dos niveis de exposição à doença periodontal, assim como para comparar a extensão da doença periodontal nos grupos caso e controle, por meio do teste de proporção. Para testar a severidade da doença periodontal e o nivel de inserção periodontal médio entre os grupos, foi aplicado o teste de média. Ambos os testes foram analisados no nível de significância de 5\%.

Foi aplicada a Análise de Regressão Logística Binomial (SAS ${ }^{106}$ 1998) ao nível de significância de $5 \%$ para deteç̧ão de fatores de risco para a ocorrência do parto a pré-termo e peso do bebê ao nascer inferior a 2.500 gramas. 


\subsubsection{Aspectos éticos}

$O$ projeto de pesquisa que deu origem a este trabalho foi submetido e aprovado pelos Comitês de Ética em Pesquisa do Hospital Municipal Vereador José Storópoli (Hospital Vila Maria), do Hospital São Paulo, do Hospital Ipiranga e da Faculdade de Saúde Pública da Universidade de São Paulo.

Para as puérperas sem doença periodontal, foram dadas orientações sobre a natureza da infecção periodontal, seu agente causal e a susceptibilidade do hospedeiro; sobre sua patogenia e meios de preveni-la, sendo enfatizada a importância de corretos hábitos de higiene bucal, bem como noções de higiene bucal para cuidados com a criança, principalmente a partir do nascimento dos primeiros dentes, em torno dos seis meses de idade.

Para as puérperas portadoras de doença periodontal, foram dadas, além das orientações citadas no parágrafo anterior, recomendações para busca de serviços odontológicos, públicos ou privados, para tratamento da infecção periodontal, sendo enfatizadas as possíveis conseqüências da doença periodontal sem tratamento adequado. Encontra-se anexo termo de aceitação das puérperas pela Disciplina de Semiologia, responsável pela triagem de pacientes com vistas a tratamento odontológico na Clínica Odontológica da Faculdade de Odontologia da USP (anexo 8).

Nas situações clínicas que requeriam pronto-atendimento odontológico, como casos de dor ou presença de lesões bucais sugestivas de processos malignos, por exemplo, as puérperas foram encaminhadas para 0 setor de emergência da 
Associação Paulista dos Cirurgiões-Dentistas (APCD), conforme termo de aceitação da Instituição (anexo 9).

Nove $(3,46 \%)$ dentre as 260 pré-selecionadas se recusaram a participar do estudo.

Todas as puérperas tiveram seu anonimato garantido. $\mathrm{O}$ sigilo dos dados individuais foi assegurado. 


\section{RESULTADOS}

O presente capítulo foi dividido em três partes. Na primeira parte serão apresentados resultados relacionados a características individuais, história reprodutiva e intercorrências clínicas das puérperas, sem a inclusão da doença periodontal. Na segunda parte, serão apresentados resultados relacionados a variável “doença periodontal", com suas respectivas categorias.

Uma avaliação conjunta de todas as variáveis foi realizada através da Análise de Regressão Logistica Binomial (SAS $\left.{ }^{106} 1998\right)$ na terceira parte deste capitulo.

5.1 Aspectos relacionados a características individuais, história reprodutiva e intercorrências clínicas

\subsubsection{Descrição da população de estudo}

Das 174 puérperas que satisfizeram os critérios de inclusão estabelecidos para o presente estudo, em 103 a ocorrência do parto foi no termo e o peso do bebê ao nascer foi maior ou igual a 2.500 gramas. E em 71, o parto foi a pré-termo, com peso do bebê ao nascer inferior a 2.500 gramas, conforme mostra a Tabela 1 . 
Tabela 1 - Número e porcentagem de puérperas segundo a idade gestacional e peso do bebê ao nascer. Hospitais: São Paulo, Vila Maria e Ipiranga, agosto/2000 a setembro/2001

\begin{tabular}{lcc}
\hline Idade gestacional e peso do bebê ao nascer & $\mathrm{N}$ & $\%$ \\
\hline Ocorrência do parto no termo e peso do bebê $\geq 2.500$ gramas & 103 & 59,2 \\
Ocorrência do parto a pré-termo e peso do bebê $<2.500$ gramas & 71 & 40,8 \\
\hline Total & 174 & 100,0 \\
\hline
\end{tabular}

Com relação à idade materna, expressa em anos completados até a data da parturição, a maior freqüência de puérperas concentrou-se na faixa etária de 21 a 25 anos (Tabela 2). Essas puérperas apresentavam idade média igual a 24,3 anos, com desvio padrão de 5,3 anos.

A distribuição da idade materna mostrou que $25,0 \%$ das puérperas tinham até 20 anos de idade; a idade mediana encontrada foi de 23 anos, e $75,0 \%$ das puérperas apresentavam até 29 anos de idade. A puérpera mais jovem tinha 17 anos e a mais velha, 35 anos de idade.

A idade média encontrada no grupo de puérperas com ocorrência do parto no termo e peso do bebê ao nascer maior ou igual a 2.500 gramas foi de 24,7 anos, com desvio padrão de 5,4 anos. As puérperas com ocorrência do parto a pré-termo e peso do bebê ao nascer inferior a 2.500 gramas apresentavam idade média de 23,7 anos, com um desvio padrão de 5,1 anos, não diferindo do ponto de vista estatístico. 
Tabela 2 - Número e porcentagem de puérperas segundo a idade materna. Hospitais:

São Paulo, Vila Maria e Ipiranga, agosto/2000 a setembro/2001

\begin{tabular}{lcc}
\hline Faixa etária (em anos) & $\mathrm{N}$ & $\%$ \\
\hline $17-20$ & 16 & 9,2 \\
$21-25$ & 91 & 52,3 \\
$26-30$ & 42 & 24,1 \\
$31-35$ & 25 & 14,4 \\
\hline Total & 174 & 100,0 \\
\hline
\end{tabular}

Aproximadamente $70,0 \%$ das puérperas relataram ter uma situação conjugal estável, vivendo maritalmente com um parceiro constante (Tabela 3).

Tabela 3 -Número e porcentagem de puérperas segundo a situação conjugal. Hospitais: São Paulo, Vila Maria e Ipiranga, agosto/2000 a setembro/2001

\begin{tabular}{lcc}
\hline Situação conjugal & N & $\%$ \\
\hline Casada ou com vida conjugal & 124 & 71,3 \\
Solteira, divorciada ou viúva & 40 & 23,0 \\
Sem informação & 10 & 5,7 \\
\hline Total & 174 & 100,0 \\
\hline
\end{tabular}

Uma baixa porcentagem de puérperas $(4,0 \%)$ não realizou pré-natal (Tabela

4). 
Tabela 4 - Número e porcentagem de puérperas segundo a realização de pré-natal.

Hospitais: São Paulo, Vila Maria e Ipiranga, agosto/2000 a setembro/2001

\begin{tabular}{lcc}
\hline Pré-natal & N & $\%$ \\
\hline Sim & 167 & 96,0 \\
Não & 7 & 4,0 \\
\hline Total ' & 174 & 100,0 \\
\hline
\end{tabular}

Dentre as 167 puérperas que fizeram consultas pré-natais, cerca de 75,0\% (126) iniciaram suas visitas ao obstetra ainda no primeiro trimestre do período gestacional (Tabela 5).

Tabela 5 - Número e porcentagem de puérperas segundo o trimestre de início dos cuidados pré-natais. Hospitais: São Paulo, Vila Maria e Ipiranga, agosto/2000 a setembro/2001

\begin{tabular}{lcc}
\hline Início do pré-natal & $\mathrm{N}$ & $\%$ \\
\hline Primeiro trimestre & 126 & 72,4 \\
Segundo trimestre & 37 & 21,3 \\
Terceiro trimestre & 1 & 0,6 \\
Não fez pré-natal & 7 & 4,0 \\
Sem informação & 3 & 1,7 \\
\hline Total & 174 & 100,0 \\
\hline
\end{tabular}


Em relação ao número total de consultas realizadas no periodo pré-natal, verificou-se que $23,6 \%$ das puérperas fizeram oito visitas ou mais ao obstetra (Tabela $6)$.

Tabela 6 - Número e porcentagem de puérperas segundo o número de consultas no pré-natal. Hospitais: São Paulo, Vila Maria e Ipiranga, agosto/2000 a setembro/2001

\begin{tabular}{lcc}
\hline Número de consultas & $\mathrm{N}$ & $\%$ \\
\hline Não fez pré-natal & 7 & 4,0 \\
De uma a sete visitas & 125 & 71,8 \\
Oito visitas ou mais & 41 & 23,6 \\
Sem informação & 1 & 0,6 \\
\hline Total & 174 & 100,0 \\
\hline
\end{tabular}

A distribuição das puérperas segundo o local de realização do pré-natal mostra que a maior concentração deu-se na rede oficial $(78,2 \%)$ (Tabela 7 ). 
Tabela 7 - Número e porcentagem de puérperas segundo o local de realização do pré-natal. Hospitais: São Paulo, Vila Maria e Ipiranga, agosto/2000 a setembro/2001

\begin{tabular}{lcc}
\hline Local & $\mathrm{N}$ & $\%$ \\
\hline Rede oficial & 136 & 78,2 \\
Serviço universitário & 21 & 12,1 \\
Convênio/particular & 9 & 5,2 \\
Não fez pré-natal & 7 & 4,0 \\
Sem informação & 1 & 0,5 \\
\hline Total & 174 & 100,0 \\
\hline
\end{tabular}

A Tabela 8 apresenta a distribuição das puérperas segundo o IMC pré-gravidico. A maior concentração deu-se na faixa de normalidade, com $35,6 \%$ das puérperas, seguida pela faixa de sobrepeso $(12,6 \%)$. A faixa de obesidade foi a de menor ocorrência, com somente três puérperas $(1,7 \%)$. 
Tabela 8 - Número e porcentagem de puérperas segundo o IMC pré-gravidico. Hospitais: São Paulo, Vila Maria e Ipiranga, agosto/2000 a setembro/2001

\begin{tabular}{lcc}
\hline IMC & $\mathrm{N}$ & $\%$ \\
\hline Baixo peso & 9 & 5,2 \\
Normalidade & 62 & 35,6 \\
Sobrepeso & 22 & 12,6 \\
Obesidade & 3 & 1,7 \\
Sem informação & 78 & 44,8 \\
\hline Total & 174 & 100,0 \\
\hline
\end{tabular}

Dentre os 174 nascimentos, $124(71,3 \%)$ ocorreram por via vaginal e 50 $(28,7 \%)$ foram cesarianas (Tabela 9). A distribuição dos nascimentos por sexo é mostrada na Tabela 10.

Tabela 9 - Número e porcentagem de puérperas segundo o tipo de parturição atual. Hospitais: São Paulo, Vila Maria e Ipiranga, agosto/2000 a setembro/2001

\begin{tabular}{lcc}
\hline Tipo de parturição & $\mathrm{N}$ & $\%$ \\
\hline Cesariana & 50 & 28,7 \\
Via vaginal & 124 & 71,3 \\
\hline Total & 174 & 100,0 \\
\hline
\end{tabular}


Tabela 10 - Número e porcentagem de puérperas segundo o sexo do recém-nato. Hospitais: São Paulo, Vila Maria e Ipiranga, agosto/2000 a setembro/2001

\begin{tabular}{lcc}
\hline Sexo do recém-nato & $\mathrm{N}$ & $\%$ \\
\hline Feminino & 74 & 42,5 \\
Masculino & 100 & 57,5 \\
\hline Total & 174 & 100,0 \\
\hline
\end{tabular}

Nenhum caso de etilismo foi encontrado, embora deva ser levado em consideração o fato de esse resultado basear-se em uma declaração verbal, sem a realização de qualquer exame complementar para confirmar a informação.

Cinqüenta e oito por cento das puérperas relataram nunca ter desenvolvido hábito de fumar. Das 73 puérperas fumantes em época anterior ao último período gestacional, levando-se em consideração uma puérpera que não respondeu quantas unidades de cigarro consumia ao dia, $64,4 \%$ relataram consumir diariamente no máximo dez unidades (Tabela 11).

Dentre as fumantes, 37 puérperas relataram ter adquirido o hábito de fumar há menos de dez anos (Tabela 12), enquanto quatro puérperas não souberam relatar há quantos anos tinham esse hábito. 
Tabela 11 - Número e porcentagem de puérperas segundo o número de cigarros consumidos por dia em periodo anterior à última gestação. Hospitais: São Paulo, Vila Maria e Ipiranga, agosto/2000 a setembro/2001

\begin{tabular}{lcc}
\hline Número de cigarros & N & $\%$ \\
\hline Fuma de l a 10 cigarros por dia & 47 & 27,0 \\
Fuma de 11 a 20 cigarros por dia & 21 & 12,1 \\
Fuma 21 ou mais cigarros por dia & 4 & 2,3 \\
Não fuma & 101 & 58,0 \\
Sem informação & 1 & 0,6 \\
\hline Total & 174 & 100,0 \\
\hline
\end{tabular}

Tabela 12 - Número e porcentagem de puérperas segundo o hábito de fumar estimado em anos. Hospitais: São Paulo, Vila Maria e Ipiranga, agosto/2000 a setembro/2001

\begin{tabular}{lcc}
\hline Hábito de fumar (em anos) & $\mathrm{N}$ & $\%$ \\
\hline Fuma há menos de 10 anos & 37 & 21,3 \\
Fuma há 10 anos ou mais & 32 & 18,4 \\
Não fuma & 101 & 58,0 \\
Sem informação & 4 & 2,3 \\
\hline Total & 174 & 100,0 \\
\hline
\end{tabular}

Dentre as 47 puérperas que fumavam de um a dez cigarros por dia, aproximadamente $40,0 \%$ desenvolveram esse hábito há dez anos ou mais. Dentre as 21 que fumavam de onze a vinte cigarros ao dia, $62,0 \%$ adquiriram esse hábito há menos de dez anos, $28,6 \%$, há dez anos ou mais e somente 2 puérperas não responderam há quantos anos desenvolveram esse hábito. 
Dentre as 73 tabagistas, uma puérpera fumava mais de vinte cigarros por dia há dez anos ou mais.

Embora o estudo faça referência a 73 puérperas fumantes previamente ao último periodo gestacional, durante a última gravidez das setenta e três, 43 (59\%) puérperas ainda continuaram a fumar (Tabela 13), levando-se em consideração as seis puérperas que não declararam a quantidade de cigarros consumidos ao dia.

Tabela 13 - Número e porcentagem de puérperas segundo o número de cigarros consumidos por dia durante a última gestação, dentre o grupo de puérperas que fumava antes do último período gestacional. Hospitais: São Paulo, Vila Maria e Ipiranga, agosto/2000 a setembro/2001

\begin{tabular}{lcc}
\hline Número de cigarros & N & $\%$ \\
\hline Fuma de l a 10 cigarros por dia & 31 & 42,5 \\
Fuma Il ou mais cigarros por dia & 6 & 8,2 \\
Não fuma & 30 & 41,1 \\
Sem informação & 6 & 8,2 \\
\hline Total & 73 & 100,0 \\
\hline
\end{tabular}

Dentre as 43 puérperas fumantes durante o último periodo gestacional, seis fumavam onze ou mais cigarros por dia. Em $72,1 \%$ das puérperas, o consumo de tabaco não ultrapassou a dez unidades diárias.

Quase a totalidade das puérperas $(93,7 \%)$ respondeu "não" ao quesito "uso de drogas ilícitas", porém dentre as puérperas que relataram fazer uso habitual ou relataram ter sido usuárias no passado (Tabela 14), a droga de eleição mais citada foi a maconha (nove puérperas usuárias), seguida do “crack" (duas puérperas usuárias). 
Tabela 14 - Número e porcentagem de puérperas segundo o uso de drogas ilícitas. Hospitais: São Paulo, Vila Maria e Ipiranga, agosto/2000 a setembro/2001

\begin{tabular}{lcc}
\hline Uso de drogas ilícitas & $\mathrm{N}$ & $\%$ \\
\hline Nunca usou & 163 & 93,7 \\
Usa/já usou & 11 & 6,3 \\
\hline Total & 174 & 100,0 \\
\hline
\end{tabular}

De acordo com os dados coletados durante a realização da entrevista avançada e as consultas ao prontuário hospitalar, das 174 puérperas participantes do estudo, $25(14,4 \%)$ já tinham tido pelo menos um parto prematuro anterior (Tabela 15). Vale a pena ressaltar que nenhuma apuração adicional sobre os partos ocorridos anteriormente à parturição atual, como consultas aos registros da idade gestacional do concepto, à ultra-sonografia obstétrica precoce e aos registros de índices neonatais, pôde ser realizada para confirmação das informações prestadas pelas puérperas sobre essa condição.

Tabela 15 - Número e porcentagem de puérperas segundo a ocorrência de parto prematuro prévio. Hospitais: São Paulo, Vila Maria e Ipiranga, agosto/2000 a setembro/2001

\begin{tabular}{lcc}
\hline Parto prematuro prévio & N & $\%$ \\
\hline Sim & 25 & 14,4 \\
Não & 147 & 84,5 \\
Sem informação & 2 & 1,1 \\
\hline Total & 174 & 100,0 \\
\hline
\end{tabular}


Para a variável aborto, $78,7 \%$ das puérperas relataram nunca ter sofrido ou praticado aborto previamente (Tabela 16).

Tabela 16 - Número e porcentagem de puérperas segundo a ocorrência de aborto prévio. Hospitais: São Paulo, Vila Maria e Ipiranga, agosto/2000 a setembro/2001

\begin{tabular}{lcc}
\hline Aborto prévio & N & $\%$ \\
\hline Sim & 35 & 20,1 \\
Não & 137 & 78,7 \\
Sem informação & 2 & 1,1 \\
\hline Total & 174 & 100,0 \\
\hline
\end{tabular}

A distribuição das puérperas segundo o número de vezes em que estiveram grávidas, incluindo a última gestação, está apresentada na Tabela 17. Uma pequena diferença percentual foi encontrada entre a ocorrência de primigestas e multigestas dentre as puérperas avaliadas.

Tabela 17 - Número e porcentagem de puérperas segundo o número de gestações, incluindo a última. Hospitais: São Paulo, Vila Maria e Ipiranga, agosto/2000 a setembro/2001

\begin{tabular}{lcc}
\hline Gestações & N & $\%$ \\
\hline Primigesta & 74 & 42,5 \\
Multigesta & 82 & 47,1 \\
Grande multigesta & 17 & 9,8 \\
Sem informação & 1 & 0,6 \\
\hline Total & 174 & 100,0 \\
\hline
\end{tabular}


Cabe destacar a ocorrência de uma baixa concentração de puérperas com história reprodutiva de cinco partos concluídos ou mais, excluindo-se a última parturição. Aproximadamente $53,0 \%$ das puérperas são nuliparas; ao se comparar a distribuição de puérperas com ocorrência prévia de um único parto ou de dois a quatro, excluindo-se a última parturição, pôde-se observar uma diferença percentual muito pequena (Tabela 18).

Tabela 18 - Número e porcentagem de puérperas segundo o número de partos concluídos, excluindo-se a última parturição. Hospitais: São Paulo, Vila Maria e Ipiranga, agosto/2000 a setembro/2001

\begin{tabular}{lcc}
\hline Partos concluidos & $\mathrm{N}$ & $\%$ \\
\hline Nulípara & 92 & 52,9 \\
Primipara & 40 & 23,0 \\
Multipara & 35 & 20,1 \\
Grande multípara & 5 & 2,9 \\
Sem informação & 2 & 1,1 \\
\hline Total & 174 & 100,0 \\
\hline
\end{tabular}

A partir dos relatos obtidos a respeito da história médica e obstétrica de cada puérpera, não foram encontradas prevalências discrepantes quanto à presença ou à ausência de infecções do trato genitourinário durante o último periodo gestacional (Tabela 19). 
Tabela 19 - Número e porcentagem de puérperas segundo a ocorrência de infecções do trato genitourinário durante o último periodo gestacional. Hospitais: São Paulo, Vila Maria e Ipiranga, agosto/2000 a setembro/2001

\begin{tabular}{lcc}
\hline Infecções do trato genitourinário & $\mathrm{N}$ & $\%$ \\
\hline Sim & 89 & 51,1 \\
Não & 82 & 47,1 \\
Sem informação & 3 & 1,7 \\
\hline Total & 174 & 100,0 \\
\hline
\end{tabular}

A distribuição do diabetes mellitus dentre as 174 puérperas selecionadas para o estudo é apresentada na Tabela 20.

Tabela 20 - Número e porcentagem de puérperas segundo a ocorrência de diabetes mellitus. Hospitais: São Paulo, Vila Maria e Ipiranga, agosto/2000 a setembro/2001

\begin{tabular}{lcc}
\hline Diabetes mellitus & N & $\%$ \\
\hline Sim & 4 & 2,3 \\
Não & 170 & 97,7 \\
\hline Total & 174 & 100,0 \\
\hline
\end{tabular}

A ocorrência de hipertensão arterial na população de estudo pode ser observada na Tabela 21. 
Tabela 21 - Número e porcentagem de puérperas segundo a ocorrência de hipertensão arterial. Hospitais: São Paulo, Vila Maria e Ipiranga, agosto/2000 a setembro/2001

\begin{tabular}{lcc}
\hline Hipertensão arterial & N & $\%$ \\
\hline Sim & 30 & 17,2 \\
Não & 144 & 82,8 \\
\hline Total & 174 & 100,0 \\
\hline
\end{tabular}

Com relação às condições sócio-demográficas, as informações revelam uma certa homogeneidade quanto ao tipo de moradia e ocupação das puérperas. Mais de $90,0 \%$ das puérperas selecionadas para o presente estudo residem em moradias cujo material de construção predominante é a alvenaria e cerca de $47,0 \%$ têm habitação própria.

Com relação à ocupação materna, observam-se pequenas mudanças na distribuição das puérperas em relação as atividades desenvolvidas antes e durante o último período gestacional. Durante a última gestação, houve um aumento no número de puérperas distribuídas na categoria "do lar" (de 60 para 77), uma diminuição no número de puérperas distribuídas nas categorias "estudante" e "trabalhadora autônoma" (de 59 para 45) e pequenas alterações nas distribuições nas categorias "desempregada" e "trabalhadora registrada". A única categoria em que as distribuições permaneceram constantes dentre os dois periodos considerados foi a de "trabalhadora eventual".

Embora apenas 2,3\% das puérperas sejam analfabetas, das $107(61,5 \%)$ puérperas distribuídas na categoria "primeiro grau completo/incompleto e segundo 
grau incompleto", $92(86,0 \%)$ interromperam os seus estudos antes de completarem o primeiro grau (Tabela 22).

Tabela 22 -Número e porcentagem de puérperas segundo o nível de escolaridade materna. Hospitais: São Paulo, Vila Maria e Ipiranga, agosto/2000 a setembro/2001

\begin{tabular}{lcc}
\hline Escolaridade & $\mathrm{N}$ & $\%$ \\
\hline Analfabeta & 4 & 2,3 \\
Primeiro grau completo/incompleto & 107 & 61,5 \\
Segundo grau completo/incompleto & 59 & 33,9 \\
Nível superior & 4 & 2,3 \\
\hline Total & 174 & 100,0 \\
\hline
\end{tabular}

\subsubsection{Associação de variáveis}

A associação de cada variável qualitativa e a variável resposta (caso-controle) foi analisada utilizando-se o Teste $x^{2}$ ou Teste Exato de Fisher. A ocorrência do parto a pré-termo e do peso do bebê ao nascer inferior a 2.500 gramas (caso) foi utilizada como eixo condutor da análise.

Nas Tabelas 23, 24 e 25, são apresentadas, respectivamente, variáveis demográficas, variáveis relacionadas aos cuidados pré-natais e variáveis de interesse, com suas respectivas categorias. Para cada variável de cada tabela é apresentada a probabilidade de significância encontrada no teste, sendo tomadas as decisões no nível de $5 \%$. 
Tabela 23 - Número e porcentagem de puérperas segundo a ocorrência do parto a pré-termo, peso do bebê ao nascer inferior a 2.500 gramas e variáveis demográficas. Hospitais: São Paulo, Vila Maria e Ipiranga, agosto/2000 a setembro/2001

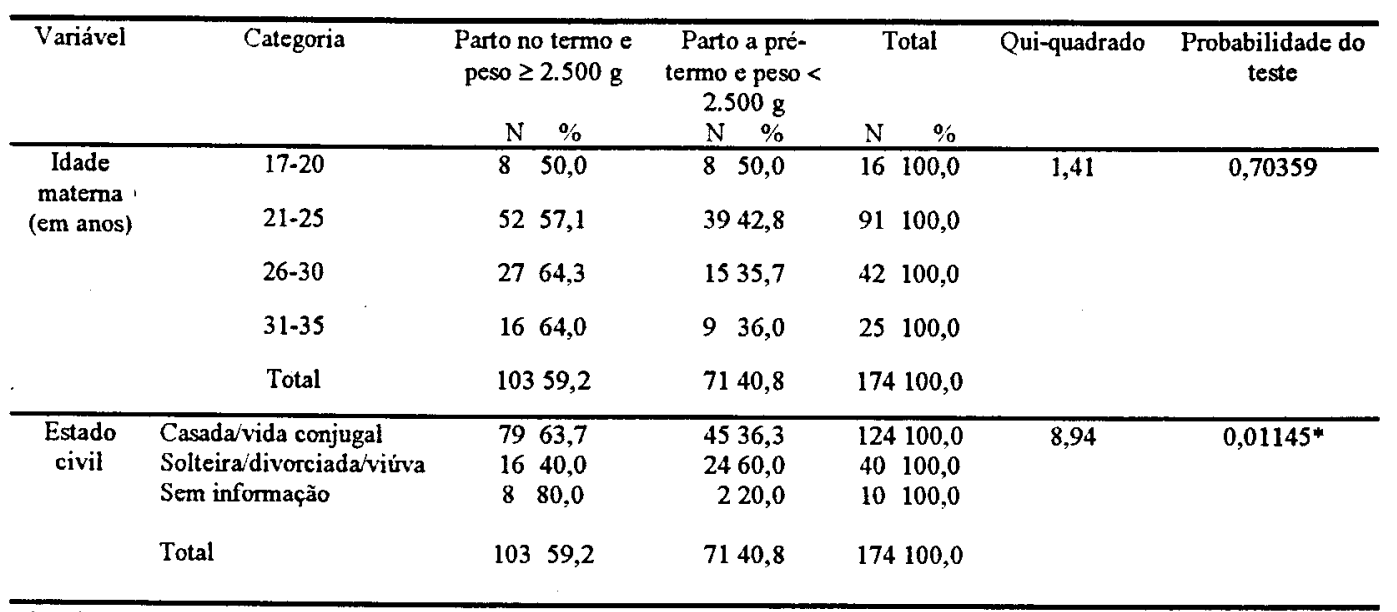

* Significativo no nível de $5 \%$

A possibilidade de associação da idade materna com a ocorrência do parto a pré-termo e de peso do bebê ao nascer inferior a 2.500 gramas não foi confirmada ( $p$ $=0,7035)($ Tabela 23$)$.

Uma associação estatisticamente significativa, com $p=0,01145$, foi verificada entre situação conjugal e ocorrência do parto prematuro com baixo peso ao nascer (Tabela 23). 
Tabela 24 - Número e porcentagem de puérperas segundo a ocorrência do parto a pré-termo, peso do bebê ao nascer inferior a 2.500 gramas e variáveis relacionadas aos cuidados pré-natais. Hospitais: São Paulo, Vila Maria e Ipiranga, agosto/2000 a setembro/2001

\begin{tabular}{|c|c|c|c|c|c|c|c|c|c|}
\hline \multirow[t]{2}{*}{ Variável } & \multirow[t]{2}{*}{ Categoria } & \multicolumn{2}{|c|}{$\begin{array}{l}\text { Parto no termo e } \\
\text { peso } \geq 2.500 \mathrm{~g}\end{array}$} & \multicolumn{2}{|c|}{$\begin{array}{c}\text { Parto a pré-termo e } \\
\text { peso }<2.500 \mathrm{~g}\end{array}$} & \multicolumn{2}{|c|}{ Total } & \multirow[t]{2}{*}{$\begin{array}{c}\text { Qui- } \\
\text { quadrado }\end{array}$} & \multirow[t]{2}{*}{$\begin{array}{c}\text { Probabilidade } \\
\text { do teste }\end{array}$} \\
\hline & & $\mathrm{N}$ & $\%$ & $\mathrm{~N}$ & $\%$ & $\mathrm{~N}$ & $\%$ & & \\
\hline \multirow{3}{*}{$\begin{array}{l}\text { Realização } \\
\text { de pré-natàl }\end{array}$} & Sim & 101 & 60,5 & $\overline{66}$ & 39,5 & 167 & 100,0 & 2,83 & 0,09241 \\
\hline & Não & 2 & 28,6 & 5 & 71,4 & 7 & 100,0 & & \\
\hline & Total & 103 & 59,2 & 71 & 40,8 & 174 & 100,0 & & \\
\hline \multirow{6}{*}{$\begin{array}{l}\text { Início do } \\
\text { pré-natal }\end{array}$} & Primeiro trimestre & $\overline{80}$ & 63,5 & $\overline{46}$ & 36,5 & 126 & 100,0 & 6,37 & 0,17335 \\
\hline & Segundo trimestre & 20 & 54,0 & 17 & 46,0 & 37 & 100,0 & & \\
\hline & Terceiro trimestre & - & - & 1 & 100,0 & 1 & 100,0 & & \\
\hline & Não fez pré-natal & 2 & 28,6 & 5 & 71,4 & 7 & 100,0 & & \\
\hline & Sem informação & 1 & 33,3 & 2 & 66,7 & 3 & 100,0 & & \\
\hline & Total & 103 & 59,2 & 71 & 40,8 & 174 & 100,0 & & \\
\hline Número de & Oito consultas ou mais & 35 & 85,4 & 6 & 14,6 & 41 & 100,0 & 17,71 & $0,00050^{*}$ \\
\hline consultas & De uma a sete consultas & 65 & 52,0 & 60 & 48,0 & 125 & 100,0 & & \\
\hline \multirow[t]{3}{*}{ pré-natais } & Não fez pré-natal & 2 & 28,6 & 5 & 71,4 & 7 & 100,0 & & \\
\hline & Sem informação & 1 & 100,0 & - & - & 1 & 100,0 & & \\
\hline & Total & 103 & 59,2 & 71 & 40,8 & 174 & 100,0 & & \\
\hline \multirow{6}{*}{$\begin{array}{l}\text { Local de } \\
\text { realização } \\
\text { do pré-natal }\end{array}$} & Rede oficial & 83 & 52,7 & 53 & 47,3 & 136 & 100,0 & 7,86 & $0,04909^{*}$ \\
\hline & Serviço universitário & 15 & 60,7 & 6 & 39,3 & 21 & 100,0 & & \\
\hline & Convênio/particular & 3 & 33,3 & 6 & 66,7 & 9 & 100,0 & & \\
\hline & Não fez pré-natal & 2 & 52,6 & 5 & 47,4 & 7 & 100,0 & & \\
\hline & Sem informação & - & - & 1 & 100,0 & 1 & 100,0 & & \\
\hline & Total & 103 & 59.2 & 71 & 40,8 & 174 & 100,0 & & \\
\hline
\end{tabular}

* Significativo no nível de $5 \%$

Quando as variáveis relacionadas aos cuidados pré-natais e suas respectivas categorias foram analisadas, o local de realização do pré-natal $(p=0,0490)$ e 0 número de consultas realizadas $(p=0,00050)$ apresentaram associações significativas com a ocorrência do parto a pré-termo e peso do bebê ao nascer inferior a 2.500 gramas (Tabela 24). 
Tabela 25 - Número e porcentagem de puérperas segundo a ocorrência do parto a pré-termo, peso do bebê ao nascer inferior a 2.500 gramas e variáveis de interesse. Hospitais: São Paulo, Vila Maria e Ipiranga, agosto/2000 a setembro/2001

\begin{tabular}{|c|c|c|c|c|c|c|c|c|c|}
\hline \multirow[t]{2}{*}{ Variável } & \multirow[t]{2}{*}{ Categoria } & \multicolumn{2}{|c|}{$\begin{array}{l}\text { Parto no termo e peso } \\
\geq 2.500 \mathrm{~g}\end{array}$} & \multicolumn{2}{|c|}{$\begin{array}{l}\text { Parto a pre-termo } \\
\text { e peso }<2.500 \mathrm{~g}\end{array}$} & \multicolumn{2}{|c|}{ Total } & \multirow[t]{2}{*}{$\begin{array}{c}\text { Qui- } \\
\text { quadrado }\end{array}$} & \multirow[t]{2}{*}{$\begin{array}{l}\text { Probabilidade } \\
\text { do teste }\end{array}$} \\
\hline & & $\mathrm{N}$ & $\%$ & $\mathrm{~N}$ & $\%$ & $\mathrm{~N}$ & $\%$ & & \\
\hline \multirow[t]{6}{*}{$\mathrm{MIC}$} & Baixo peso & 5 & 55,6 & 4 & $\overline{44,4}$ & 9 & 100,0 & 3,23 & 0,52076 \\
\hline & Normalidade & 34 & 54,8 & 28 & 45,2 & 62 & 100,0 & & \\
\hline & Sobrepeso & 12 & 54,5 & 10 & 45,5 & 22 & 100,0 & & \\
\hline & Jbesidade & & 100,0 & - & - & 3 & 100,0 & & \\
\hline & Šm informação & 49 & 62,8 & 29 & 37,2 & 78 & 100,0 & & \\
\hline & Total & 103 & 59,2 & 71 & 40,8 & 174 & 100,0 & & \\
\hline \multirow[t]{3}{*}{ Sexo do bebê } & Feminino & 44 & 59,4 & 30 & 40,5 & 74 & 100,0 & 0,00 & 0,95138 \\
\hline & Masculino & 59 & 59,0 & 41 & 41,0 & 100 & 100,0 & & \\
\hline & Total & 103 & 59.2 & 71 & 40,8 & 174 & 100,0 & & \\
\hline
\end{tabular}

* Significativo no nível de $5 \%$

Uma associação significativa entre sexo do bebê e ocorrência do parto prematuro associado ao baixo peso ao nascimento não foi confirmada $(p=0,9513)$ (Tabela 25).

Não foi detectada uma associação significativa $(p=0,5207)$ entre o IMC pré-gravídico e a ocorrência do parto a pré-termo com peso do bebê ao nascer inferior a 2.500 gramas (Tabela 25).

As Tabelas 26, 27 e 28 apresentam, respectivamente, variáveis relacionadas ao uso de drogas ilícitas e tabaco, à história reprodutiva das puérperas e à ocorrência de intercorrências clínicas, com suas respectivas categorias e significância estatística. 
Tabela 26 - Número e porcentagem de puérperas segundo a ocorrência do parto a pré-termo, peso do bebê ao nascer inferior a 2.500 gramas e variáveis relacionadas ao uso de drogas ilicitas e tabaco. Hospitais: São Paulo, Vila Maria e Ipiranga, agosto/2000 a setembro/2001

\begin{tabular}{|c|c|c|c|c|c|c|c|c|c|}
\hline \multirow[t]{3}{*}{ Variável } & \multirow[t]{3}{*}{ Categoria } & \multirow{2}{*}{\multicolumn{2}{|c|}{$\begin{array}{l}\text { Parto no termo e } \\
\text { peso } \geq 2.500 \mathrm{~g}\end{array}$}} & \multicolumn{2}{|c|}{ Parto a pré-termo } & \multirow{2}{*}{\multicolumn{2}{|c|}{ Total }} & \multirow{3}{*}{$\begin{array}{c}\text { Qui- } \\
\text { quadrado }\end{array}$} & \multirow{3}{*}{$\begin{array}{l}\text { Probabilida- } \\
\text { de do teste }\end{array}$} \\
\hline & & & & e peso & $<2.500 \mathrm{~g}$ & & & & \\
\hline & & $\mathrm{N}$ & $\%$ & $\mathrm{~N}$ & $\%$ & $\mathrm{~N}$ & $\%$ & & \\
\hline \multirow{3}{*}{$\begin{array}{l}\text { Uso de drogas } \\
\text { ilicitas }\end{array}$} & Nunca usou & 99 & 60,7 & 64 & 39,3 & 163 & 100,0 & 2,53 & 0,11140 \\
\hline & Usa ou já usou & 4 & 36,4 & & $7 \quad 63,6$ & 11 & 100,0 & & \\
\hline & Total & 103 & 59,2 & 71 & 40,8 & 174 & 100,0 & & \\
\hline \multirow{6}{*}{$\begin{array}{l}\mathrm{N}^{0} \text { de cigarros } \\
\text { consumidos } \\
\text { por dia (antes } \\
\text { da gestação) }\end{array}$} & Não fuma & 65 & 64,3 & 36 & 35,6 & 101 & 100,0 & 13,23 & $0,01022^{\circ}$ \\
\hline & $\begin{array}{l}\text { Fuma de } 1 \text { a } 10 \\
\text { cigarros por dia }\end{array}$ & 29 & 61,7 & 18 & 38,3 & 47 & 100,0 & & \\
\hline & $\begin{array}{l}\text { Fuma de } 11 \text { a } 20 \\
\text { cigarros por dia }\end{array}$ & 5 & 23,8 & 16 & 676,2 & 21 & 100,0 & & \\
\hline & $\begin{array}{l}\text { Fuma } 21 \text { ou mais } \\
\text { cigarros por dia }\end{array}$ & 3 & 75,0 & 1 & 25,0 & 4 & 100,0 & & \\
\hline & Sem informação & 1 & 100,0 & $=$ & - & 1 & 100,0 & & \\
\hline & Total & 103 & 59,2 & 71 & 40,8 & 174 & 100,0 & & \\
\hline \multirow{5}{*}{$\begin{array}{l}\text { Tempo de } \\
\text { consumo de } \\
\text { tabaco (em } \\
\text { anos, antes da } \\
\text { gestação) }\end{array}$} & Não fuma & 65 & 64,3 & 36 & 35,6 & 101 & 100,0 & 2,78 & 0,42698 \\
\hline & Fuma há menos de 10 & 20 & 54,0 & 17 & 46,0 & 37 & 100,0 & & \\
\hline & $\begin{array}{l}\text { Fuma há } 10 \text { anos ou } \\
\text { mais }\end{array}$ & 16 & 50,0 & 16 & 50,0 & 32 & 100,0 & & \\
\hline & Sem informação & 2 & 50,0 & 2 & 50,0 & 4 & 100,0 & & \\
\hline & Total & 103 & 59,2 & 71 & 40,8 & 174 & 100,0 & & \\
\hline \multirow{5}{*}{$\begin{array}{l}\mathrm{N}^{\circ} \text { de cigarros } \\
\text { consumidos } \\
\text { por dia } \\
\text { (durante a } \\
\text { gestação) }\end{array}$} & Não fuma & 79 & 60,3 & 52 & 39,7 & 131 & 100,0 & 4,75 & 0,19067 \\
\hline & $\begin{array}{l}\text { Fuma de } \frac{1}{1} \text { a } 10 \\
\text { cigarros por dia }\end{array}$ & 19 & 61,3 & 12 & 38,7 & 31 & 100,0 & & \\
\hline & $\begin{array}{l}\text { Fuma } 11 \text { ou mais } \\
\text { cigamos por dia }\end{array}$ & 1 & 16,6 & 5 & 83,3 & 6 & 5100,0 & & \\
\hline & Sem informação & 4 & 66,6 & & 33,3 & 6 & 100,0 & & \\
\hline & Total & 103 & 59,2 & 71 & 40,8 & 174 & 100,0 & & \\
\hline
\end{tabular}

* Significativo no nível de 5\% 
$\mathrm{Na}$ análise do uso de drogas ilícitas, não foi confirmada a possível associação entre seu uso e os resultados desfavoráveis ao nascimento $(p=0,1114)$ (Tabela 26)

Quando a possibilidade de associação do uso de tabaco na gestação, com suas respectivas variáveis e categorias, foi testada, detectou-se uma associação significativa com o hábito de fumar previamente à última gestação e o nascer prematuro associado ao baixo peso $(\mathrm{p}=0,0102)$, dentre as três variáveis analisadas (Tabela 26). 
Tabela 27 - Número e porcentagem de puérperas segundo a ocorrência do parto a pré-termo, peso do bebê ao nascer inferior a 2.500 gramas e variáveis relacionadas à história reprodutiva. Hospitais: São Paulo, Vila Maria e Ipiranga, agosto/2000 a setembro/2001

\begin{tabular}{|c|c|c|c|c|c|c|c|c|c|}
\hline \multirow[t]{2}{*}{ Variável } & \multirow[t]{2}{*}{ Categoria } & \multicolumn{2}{|c|}{$\begin{array}{l}\text { Parto no termo e } \\
\text { peso } \geq 2.500 \mathrm{~g}\end{array}$} & \multicolumn{2}{|c|}{$\begin{array}{l}\text { Parto a pré-temo } \\
\text { e peso }<2.500 \mathrm{~g}\end{array}$} & \multicolumn{2}{|c|}{ Total } & \multirow[t]{2}{*}{$\begin{array}{c}\text { Qui- } \\
\text { quadrado }\end{array}$} & \multirow[t]{2}{*}{$\begin{array}{l}\text { Probabilidade } \\
\text { do teste }\end{array}$} \\
\hline & & $\mathrm{N}$ & $\%$ & $\mathrm{~N}$ & $\%$ & $\mathrm{~N}$ & $\%$ & & \\
\hline \multirow{4}{*}{$\begin{array}{l}\text { Parto } \\
\text { prematuro } \\
\text { prévio }\end{array}$} & Sim & 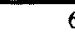 & 24,0 & 19 & 76,0 & 25 & 100,0 & 18,53 & $0,00009^{*}$ \\
\hline & Nào & $9 ?$ & 66,0 & 50 & 34,0 & 147 & 100,0 & & \\
\hline & Sem informação & - & - & & 100,0 & 2 & 100,0 & & \\
\hline & Total & 10 & 59,2 & 71 & 40,8 & 174 & 100,0 & & \\
\hline \multirow[t]{4}{*}{ Aborto prévio } & Sim & 17 & 48,6 & 18 & 51,4 & 35 & 100,0 & 5,26 & 0,07196 \\
\hline & Xào & 86 & 62.8 & 51 & 37,2 & 137 & 100,0 & & \\
\hline & Sem informação & - & - & 2 & 100,0 & 2 & 100,0 & & \\
\hline & Total & 103 & 59,2 & 71 & 40,8 & 174 & 100,0 & & \\
\hline \multirow{5}{*}{$\begin{array}{l}\text { Número de } \\
\text { gestaçōes (c/ } \\
\text { a última) }\end{array}$} & Primigesta & 43 & 58.1 & 31 & 41,9 & 74 & 100,0 & 1,71 & 0,63442 \\
\hline & Multigesta & 49 & 60,0 & 33 & 40,0 & 82 & 100,0 & & \\
\hline & $\begin{array}{l}\text { Grande } \\
\text { multigesta }\end{array}$ & & 65,0 & 6 & 35,0 & 17 & 100,0 & & \\
\hline & Sem informação & - & - & 1 & 100,0 & 1 & 100,0 & & \\
\hline & Total & 103 & 59.2 & 71 & 40.8 & 174 & 100.0 & & \\
\hline \multirow{6}{*}{$\begin{array}{l}\text { Número de } \\
\text { partos } \\
\text { concluidos (s' } \\
\text { o último) }\end{array}$} & Nulipara & 47 & 51,1 & 45 & 48,9 & 92 & 100,0 & 11,58 & $0,02077^{*}$ \\
\hline & Primípara & 26 & 65,0 & 14 & 35,0 & 40 & 100,0 & & \\
\hline & Multipara & 25 & 71,4 & 10 & 28,6 & 35 & 100,0 & & \\
\hline & Grande multipara & 5 & 00,0 & - & - & & 100,0 & & \\
\hline & Sem informação & - & - & 2 & 100,0 & & 100,0 & & \\
\hline & Total & 103 & 59,2 & 71 & 40.8 & 174 & 100.0 & & \\
\hline
\end{tabular}

* Significativo no nível de $5 \%$

Foram encontradas associações significativas entre prematuridade prévia e parto prematuro atual com baixo peso ao nascer, assim como entre história reprodutiva com múltiplos partos concluídos, excluindo-se a última parturição, e parto prematuro atual com baixo peso ao nascer ( $p<0,0001$ e $p=0,0207$, respectivamente). Quando se avaliou a possibilidade de associação entre a ocorrência de aborto prévio e a história 
reprodutiva acerca do número de gestações, incluindo a última, não foi possível detectar significância estatistica ( $p=0,0719$ e $p=0,6344$, respectivamente) (Tabela 27).

Tabela 28 - Número e porcentagem de puérperas segundo a ocorrência do parto a pré-termo, peso do bebê ao nascer inferior a 2.500 gramas e variáveis relacionadas a intercorrências clínicas. Hospitais: São Paulo, Vila Maria e Ipiranga, agosto/2000 a setembro/2001

\begin{tabular}{|c|c|c|c|c|c|c|c|c|c|}
\hline \multirow[t]{2}{*}{ Variável } & \multirow[t]{2}{*}{ Categoria } & \multicolumn{2}{|c|}{$\begin{array}{l}\text { Parto no termo e } \\
\text { peso } \geq 2.500 \mathrm{~g}\end{array}$} & \multicolumn{2}{|c|}{$\begin{array}{l}\text { Parto a pré-termo } \\
\text { e peso }<2.500 \mathrm{~g}\end{array}$} & \multicolumn{2}{|c|}{ Total } & \multirow[t]{2}{*}{$\begin{array}{c}\text { Qui- } \\
\text { quadrado }\end{array}$} & \multirow[t]{2}{*}{$\begin{array}{c}\text { Probabilidade } \\
\text { do teste }\end{array}$} \\
\hline & & $\mathrm{N}$ & $\%$ & $\mathrm{~N}$ & $\%$ & $\mathrm{~N}$ & $\%$ & & \\
\hline \multirow{4}{*}{$\begin{array}{l}\text { Oconténcia de } \\
\text { infecção } \\
\text { genital e } \\
\text { urinária } \\
\text { (durante a } \\
\text { gestação) }\end{array}$} & $\operatorname{Sin}$ & 47 & 52,8 & 42 & 47,2 & 89 & 100,0 & 4,44 & 0,10859 \\
\hline & Não & 55 & 67,1 & 27 & 32,9 & 82 & 100,0 & & \\
\hline & Sem informaçăo & 1 & 33,3 & 2 & 66,6 & 3 & 100,0 & & \\
\hline & Total & 103 & 59,2 & 71 & 40,8 & 174 & 100,0 & & \\
\hline \multirow{3}{*}{$\begin{array}{l}\text { Ocorrència de } \\
\text { diabetes } \\
\text { mellitus }\end{array}$} & $\operatorname{Sim}$ & 3 & 75,0 & 1 & 25,0 & 4 & 100,0 & 0,42 & 0,51525 \\
\hline & Não & 100 & 58,8 & 70 & 41,2 & 170 & 100,0 & & \\
\hline & Total & 103 & 59,2 & 71 & 40,8 & 174 & 100,0 & & \\
\hline Ocorrência de & $\operatorname{sim}$ & 17 & 56,6 & 13 & 43,3 & 30 & 100,0 & 0,10 & 0,75672 \\
\hline hipertensão & Nào & 86 & 59,7 & 58 & 40,3 & 144 & 100,0 & & \\
\hline arterial & Total & 103 & 59.2 & 71 & 40,8 & 174 & 100.0 & & \\
\hline
\end{tabular}

* Significativo no nivel de $5 \%$

Não foi encontrada uma associação significativa $(p=0,1085)$ entre a ocorrência de infecções do trato genitourinário durante o último periodo gestacional e o parto prematuro com baixo peso ao nascer (Tabela 28).

$\mathrm{Na}$ análise da possibilidade de associação entre a hipertensão arterial e o parto prematuro com baixo peso ao nascer e entre diabetes mellitus e a condição final da puérpera, não foram detectadas associações significativas $(p=0,5152$ e $p=$ 0,75672 , respectivamente) (Tabela 28). 
Tabela 29 - Número e porcentagem de puérperas segundo a ocorrência do parto a pré-termo, peso do bebê ao nascer inferior a 2.500 gramas e nível de escolaridade materna. Hospitais: São Paulo, Vila Maria e Ipiranga, agosto/2000 a setembro/2001

\begin{tabular}{|c|c|c|c|c|c|c|c|c|c|}
\hline \multirow[t]{2}{*}{ Variável } & \multirow[t]{2}{*}{ Categoria } & \multicolumn{2}{|c|}{$\begin{array}{l}\text { Parto no termo e } \\
\text { peso } \geq 2.500 \mathrm{~g}\end{array}$} & \multicolumn{2}{|c|}{$\begin{array}{l}\text { Parto a pré-termo } \\
\text { e peso }<2.500 \mathrm{~g}\end{array}$} & \multicolumn{2}{|c|}{ Total } & \multirow[t]{2}{*}{$\begin{array}{c}\text { Qui- } \\
\text {-quadrado }\end{array}$} & \multirow[t]{2}{*}{$\begin{array}{c}\text { Probabilidade } \\
\text { do teste }\end{array}$} \\
\hline & & $\mathrm{N}$ & $\%$ & $\mathrm{~N}$ & $\%$ & $\mathrm{~N}$ & $\%$ & & \\
\hline \multirow{6}{*}{$\begin{array}{l}\text { Escolaridade } \\
\text { materna }\end{array}$} & Analfabeta & 4 & 100,0 & - & - & 4 & 100,0 & 8,93 & $0,03021^{2}$ \\
\hline & $1^{\circ} \mathrm{grau}$ & & & & & & & & \\
\hline & completo/incompleto & 62 & 58,0 & 45 & 42,0 & 107 & 100,0 & & \\
\hline & $\begin{array}{l}2^{\circ} \text { grau } \\
\text { completo/incopleto }\end{array}$ & 37 & 62,7 & 22 & 37,3 & 59 & 100,0 & & \\
\hline & Nível superior & - & - & 4 & 100,0 & 4 & 100,0 & & \\
\hline & Total & 103 & 59,2 & 71 & 40,8 & 174 & 100,0 & & \\
\hline
\end{tabular}

* Significativo no nivel de $5 \%$

Na Tabela 29, a possivel associação da escolaridade materna foi verificada em relação à prematuridade com peso do bebê ao nascer inferior a 2.500 gramas.

\subsection{Aspectos relacionados às condições periodontais}

\subsubsection{Descrição da população de estudo}

A Tabela 30 apresenta a prevalência da doença periodontal na população de estudo. Aproximadamente $40 \%$ das puérperas examinadas são portadoras de doença periodontal destrutiva. 
Tabela 30 - Número e porcentagem de puérperas segundo a ocorrência de doença periodontal. Hospitais: São Paulo, Vila Maria e Ipiranga, agosto/2000 a setembro/2001

\begin{tabular}{lcc}
\hline Doença periodontal & N & $\%$ \\
\hline Sim & 69 & 39,7 \\
Não & 105 & 60,3 \\
\hline Total & 174 & 100,0 \\
\hline
\end{tabular}

Nas Tabelas 31 e 32, pode-se verificar o número e o percentual de puérperas que declararam ter realizado tratamento periodontal previamente à última gestação e durante o último periodo gestacional, respectivamente.

Tabela 31 - Número e porcentagem de puérperas segundo a realização de tratamento periodontal anteriormente à última gestação. Hospitais: São Paulo, Vila Maria e Ipiranga, agosto/2000 a setembro/2001

\begin{tabular}{lcc}
\hline Tratamento periodontal & N & $\%$ \\
\hline Sim & 18 & 10,3 \\
Não & 156 & 89,7 \\
\hline Total & 174 & 100,0 \\
\hline
\end{tabular}


Tabela 32 - Número e porcentagem de puérperas segundo a realização de tratamento periodontal durante o último periodo gestacional. Hospitais: São Paulo, Vila Maria e Ipiranga, agosto/2000 a setembro/2001

\begin{tabular}{lcc}
\hline Tratamento periodontal & N & $\%$ \\
\hline Sim & 4 & 2,3 \\
Não & 170 & 97,7 \\
\hline Total & & 100,0 \\
\hline
\end{tabular}

Como pode ser observado, apenas um pequeno número de puérperas declarou ter sofrido tratamento periodontal. Dezoito puérperas realizaram tratamento periodontal anteriormente ao último periodo gestacional. Quatro submeteram-se a tratamento periodontal durante o último periodo gestacional, sendo que destas, duas também realizaram tratamento periodontal previamente.

Dentre os tipos de tratamento periodontal realizados pelas puérperas, relatados durante o desenvolvimento da entrevista avançada, o mais citado foi a limpeza dental (em 13 puérperas), seguido de raspagem (em 5 puérperas). Apenas uma puérpera relatou ter sofrido cirurgia periodontal. $\mathrm{O}$ bochecho com colutório também foi relatado como tratamento de eleição realizado por uma puérpera. Devese salientar que nenhuma apuração adicional sobre o tipo de tratamento periodontal realizado pelas puérperas pôde ser realizada.

Através do exame clínico periodontal, foi possivel avaliar o nível de inserção periodontal médio de cada puérpera, sendo encontrada, para o grupo de puérperas com ocorrência do parto no termo e peso do bebê ao nascer maior ou igual a 2.500 gramas, uma distância média de 0,48 milímetros/sítio entre a junção- 
-cemento-esmalte e a porção mais apicalmente sondável. Para as puérperas com ocorrência do parto a pré-termo e peso do bebê ao nascer inferior a 2.500 gramas, essa distância foi de 0,66 milimetros/sítio, em média.

De acordo com o Índice de Extensão e Severidade da Doença Periodontal (CARLOS et al. ${ }^{12}$ 1986), 8,04\% dos sítios examinados das puérperas com ocorrência do parto no termo e peso do bebê ao nascer maior ou igual a 2.500 gramas são afetados por uma perda média de inserção periodontal de 1,87 milimetros. Para as puérperas com ocorrência do parto a pré-termo e peso do bebê ao nascer inferior a 2.500 gramas, foi encontrada uma perda média de inserção periodontal de 2,03 milímetros em $11,69 \%$ dos sítios, dentre os examinados.

\subsubsection{Associação de variáveis}

A associação de cada variável qualitativa relacionada às condições periodontais e a variável resposta (caso-controle) foi analisada utilizando-se o Teste $x^{2}$ ou Teste Exato de Fisher. A ocorrência do parto a pré-termo e peso do bebê ao nascer inferior a 2.500 gramas (caso) foi utilizada como eixo condutor da análise. A probabilidade de significância encontrada no teste será apresentada para cada variável, sendo tomadas as decisões no nível de $5 \%$. 
Tabela 33 - Número e porcentagem de puérperas segundo a ocorrência do parto a prè-termo, peso do bebê ao nascer inferior a 2.500 gramas e variáveis relacionadas à doença periodontal. Hospitais: São Paulo, Vila Maria e Ipiranga, agosto/2000 a setembro/2001

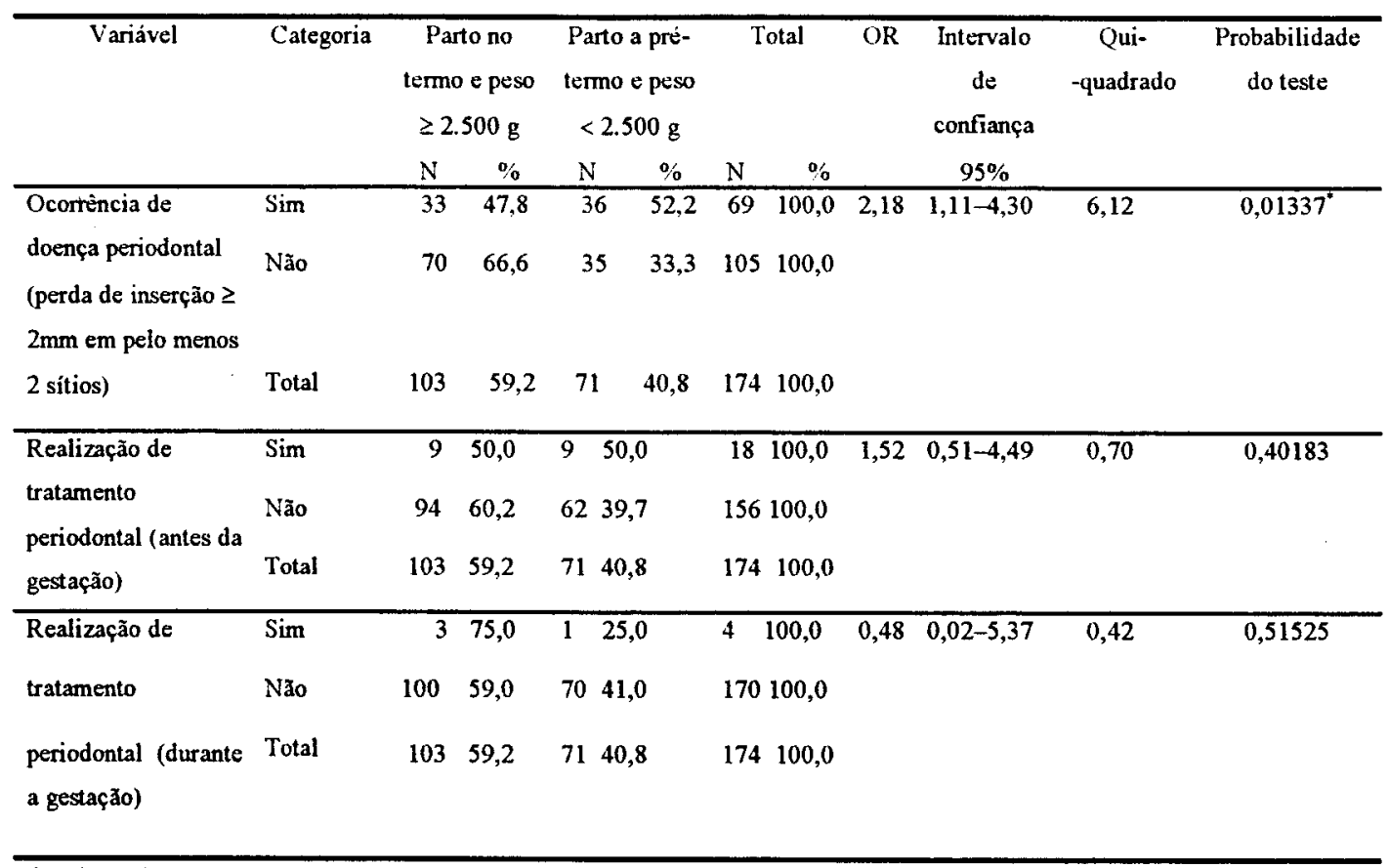

* Significativo no nível de 5\%

Quando a possibilidade de associação entre a presença da doença periodontal, considerando uma perda de inserção periodontal de dois milímetros ou mais em dois ou mais sítios, dentre os examinados, e a ocorrência do nascer prematuro associado ao baixo peso foi considerada, houve evidência estatística para aceitar a associação significativa com condições desfavoráveis ao nascimento $(\mathrm{p}=$ 0,0133) (Tabela 33).

Quando a possibilidade de associação dos outros três niveis de exposição à doença periodontal arbitrariamente escolhidos foi testada, não foram encontradas associações significativas com a ocorrência do parto prematuro com baixo peso ao 
nascer com exceção da presença de uma perda de inserção de dois milímetros ou mais em pelo menos um sitio $(\mathrm{p}=0,0292)$.

$\mathrm{Na}$ análise da possivel relação entre a realização de tratamento periodontal antes ou durante o último periodo gestacional e a condição final da puérpera, não foi confirmada associação $(p=0,4018$ e $p=0,5152$, respectivamente) (Tabela 33).

\subsubsection{Severidade da doença periodontal}

$\mathrm{Na}$ comparação da média do nivel de inserção periodontal encontrada para o grupo de puérperas com ocorrência do parto no termo e peso do bebê ao nascer maior ou igual a 2.500 gramas (média $=0,48 \mathrm{~mm}$ e desvio padrão $=0,56 \mathrm{~mm}$ ) com a observada no grupo com ocorrência do parto a pré-termo e peso do bebê ao nascer inferior a 2.500 gramas (média $=0,66 \mathrm{~mm}$ e desvio padrão $=0,88 \mathrm{~mm}$ ), não foi encontrada diferença estatisticamente significativa $(p=0,0986)$.

A severidade da doença periodontal (CARLOS et al. ${ }^{12}$ 1986) para o grupo de puérperas com ocorrência do parto no termo e peso do bebê ao nascer maior ou igual a 2.500 gramas foi $\mathrm{S}=1,9 \mathrm{~mm}$ e desvio padrão $=1,3 \mathrm{~mm}$, enquanto para o grupo das puérperas com ocorrência do parto a pré-termo e peso de nascimento inferior a 2.500 gramas, $\mathrm{S}=2,0 \mathrm{~mm}$ e desvio padrão $=1,2 \mathrm{~mm}$, não tendo sido encontrada diferença estatisticamente significativa $(p=0,4258)$ quando o teste de média foi aplicado.

\subsubsection{Extensão da doença periodontal}

A extensão da doença periodontal (CARLOS et al. ${ }^{12}$ 1986) para o grupo de puérperas com ocorrência do parto no termo e peso do bebê ao nascer maior ou igual a 2.500 gramas foi $E=8 \%$. Para o grupo das puérperas com parto a pré-termo e peso 
de nascimento inferior a 2.500 gramas foi $E=12 \%$, sendo observada uma diferença estatisticamente significativa $(p=0,0001)$ quando o teste de proporção foi aplicado.

\subsection{Análise de regressão logística binomial}

Tabela 34 - Fatores de risco para a ocorrência do parto a pré-termo e peso do bebê ao nascer inferior a 2.500 gramas, no modelo final da Análise de Regressão Logística Binomial. Hospitais: São Paulo, Vila Maria e Ipiranga, agosto/2000 a setembro/2001

\begin{tabular}{|c|c|c|c|c|c|c|c|}
\hline Variáveis & $\begin{array}{l}\text { Grau de } \\
\text { liberdade }\end{array}$ & $\begin{array}{c}\text { Coeficiente } \\
\text { (Bi) }\end{array}$ & Erro padrão & Wald & $\begin{array}{l}\text { Probabilidade } \\
\text { do teste }\end{array}$ & OR & $\begin{array}{c}\text { Intervalo de } \\
\text { confiança } \\
95 \%\end{array}$ \\
\hline Intercepto & 1 & $-2,3077$ & 0.7724 & 8.9268 & $0.0028^{*}$ & $=$ & - \\
\hline $\begin{array}{l}\text { Número de } \\
\text { consultas } \\
\text { pré-natais }\end{array}$ & 1 & 2,0907 & 0,6468 & 10,4493 & $0,0012^{*}$ & 8,0910 & $2.277-28,741$ \\
\hline $\begin{array}{l}\text { Parto } \\
\text { prematuro } \\
\text { prévio } \\
\end{array}$ & 1 & $-1,7974$ & 0,7436 & 5,8426 & $0,0156^{*}$ & 0,1660 & $0,039-0,712$ \\
\hline $\begin{array}{l}\text { Número de } \\
\text { partos } \\
\text { concluídos (s/ } \\
\text { o último) }\end{array}$ & 1 & 0,8310 & 0,3168 & 6,8792 & $0,0087^{*}$ & 2,2960 & $1,234-4,272$ \\
\hline
\end{tabular}

* Significativo no nivel de $5 \%$

As variáveis que tiveram a probabilidade do Teste de associação $x^{2}$ inferior a 0,20 entraram na Análise de Regressão Logistica Binomial (SAS 1998) para estimar o modelo, ficando confirmado que as variáveis "número de consultas pré-natais", "parto prematuro prévio" e "número de partos concluídos (sem o último)", interferem como fatores de risco ao parto prematuro e ao baixo peso ao nascer por terem mantido até o final do modelo nivel significativo de $5 \%$. 


\section{DISCUSSÃO}

Dentre os diversos fatores de risco associados à ocorrência de episódios indesejáveis durante o período gestacional, múltiplas linhas de pesquisa sustentam 0 importante papel que as infecções agudas maternas desempenham para o nascer prematuro e o nascimento de bebês com baixo peso (HILLIER et al. ${ }^{41} 1995$; GOLDENBERG et al. ${ }^{34}$ 2000; GIBBS $^{32}$ 2001).

Embora um maior risco obstétrico esteja geralmente associado à ocorrência de processos infecciosos agudos, através de diversos estudos experimentais com animais prenhes e estudos clínicos desenvolvidos em humanos, pôde-se observar que, perante a exposição crônica de agentes infecciosos periodontais, também era possível se evidenciar um aumento da toxicidade feto-placentária, com conseqüente aumento no risco de ocorrência de malformação fetal, abortos prematuros, trabalho de parto prematuro, baixo peso ao nascimento e outras complicações na gravidez (COLLINS et al. ${ }^{15,16,17} 1994 a$,b 1995; OFFENBACHER et al. ${ }^{88} 1998 b$ ).

Neste estudo, houve evidência estatística para aceitar uma associação significativa entre a presença da doença periodontal materna e o nascer prematuro de baixo peso.

Quando a possibilidade de associação entre a presença da doença periodontal e a ocorrência de resultados adversos na gravidez foi analisada, considerando como doentes periodontais as puérperas que apresentavam pelo menos dois sítios dentre os examinados com perda de inserção periodontal de dois milímetros ou mais (grau de exposição), o risco de as puérperas portadoras de doença 
periodontal terem parto prematuro e bebês com peso inferior a 2.500 gramas ao nascimento foi 2,18 vezes maior do que o das puérperas saudáveis periodontalmente. Como a escolha de pelo menos dois sítios com perda de inserção periodontal de dois milímetros ou mais foi feita de modo arbitrário, optou-se por verificar a possibilidade de associação entre a presença da doença periodontal e a ocorrência do parto prematuro com baixo peso ao nascer quando limiares diferentes caracterizando as puérperas como doentes periodontais fossem estabelecidos.

Quando o limiar de doença periodontal foi modificado para uma perda de inserção de dois milímetros ou mais, afetando pelo menos um sítio dentre os examinados (menor grau de exposição materna à doença periodontal), evidenciou-se a presença da doença periodontal em 93 das 174 puérperas avaliadas e uma diminuição no risco de essas puérperas terem parto prematuro e bebês com peso inferior a 2.500 gramas ao nascimento. Esse dado foi estabelecido em relação ao risco das puérperas saudáveis periodontalmente: de 2,18 (maior grau de exposição materna à doença periodontal) para 1,98 vezes. Esse resultado reflete o fato de que, perante a ocorrência de um menor desafio bacteriano (mesma severidade, porém menor extensão da doença periodontal), o risco materno a resultados indesejáveis na gravidez também diminui.

Quando a possibilidade de associação foi verificada entre puérperas consideradas doentes periodontais, com perda de inserção periodontal de dois milimetros ou mais em pelo menos três sítios ou em quatro sítios ou mais dentre os examinados (mesma severidade de doença, porém com uma extensão ainda maior), nenhuma associação significativa pôde ser evidenciada. Embora fosse esperado que, à medida que aumentasse o grau de exposição das puérperas à doença periodontal 
também se evidenciasse um aumento no risco para o nascer prematuro e o baixo peso, essa suposição não se confirmou, provavelmente em conseqüência do pequeno número de ocorrências de formas mais severas de doença na população de estudo.

Cabe ressaltar que, embora este estudo exiba uma maior proporção de sítios, dentre os examinados, com sinais de doença periodontal destrutiva e uma quantidade levemente maior de perda de tecido periodontal de inserção nos sítios afetados para o grupo de puérperas com ocorrência do parto a pré-termo e peso do bebê ao nascer inferior a 2.500 gramas, os resultados de extensão e severidade da doença periodontal nesse grupo sugerem a ocorrência de uma forma localizada (11,69\% dos sitios dentre os examinados) e branda (2,03 $\mathrm{mm}$ em média) de destruição tecidual.

No entanto, este estudo acrescenta um dado importante à literatura pelo fato de demonstrar que, mesmo na presença de um pequeno desafio infeccioso periodontal, existe uma associação significativa com o nascer prematuro e o baixo peso ao nascer. Isso contradiz, até certo ponto, a maioria dos dados de um número ainda limitado de estudos epidemiológicos, os quais apóiam a hipótese de que somente a presença de um processo infeccioso periodontal generalizado, de moderado a severo, aumenta o risco para efeitos adversos na gestação.

Embora a doença periodontal se caracterize por uma infecção de baixa intensidade que se perpetua por longos periodos de tempo (processo inflamatório crônico), ela é capaz de exibir importante destruição tecidual e intenso infiltrado inflamatório predominantemente linfoplasmocitário e macrofágico, principais responsáveis pela síntese de IL-1, FNT $\alpha$ e PGE2 frente a estimulos bacterianos

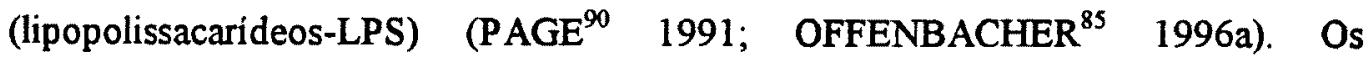
mediadores inflamatórios, tais como as prostaglandinas E2 (PGE2), não estão 
presentes somente no processo inflamatório periodontal, mas também no processo fisiológico de parturição e de prematuridade patológica. Apesar disso, pode-se observar, através de estudos realizados com modelos de gestação em animais, que as infeç̧ões periodontais representam fontes continuas de liberação de PGE2 e FNT $\alpha$, podendo afetar a unidade materno-fetal, mesmo sendo consideradas processos de baixo grau de infecção (OFFENBACHER et al. ${ }^{88}$ 1998b). Entretanto, ainda não está estabelecido se a relação entre um processo infeccioso bucal e as mudanças no ambiente fetal é resultado da síntese de PGE2 e FNT $\alpha$ pelas células corioamniônicas induzidas por lipopolissacarideos oriundos da infecção periodontal e disseminados pela corrente sanguinea ou se os próprios sítios com infecção periodontal, ao produzirem mediadores inflamatórios, passam a atuar como fonte sistêmica potencial de citocinas fetotóxicas através do sangue (COLLINS et al. ${ }^{15,16} 1994 \mathrm{a}, \mathrm{b}$ ).

Ưm outro aspecto importante a se observar é que as puérperas avaliadas neste estudo apresentam idade média de 24,3 anos e mediana de 23 anos. Sabendo-se que a ocorrência de formas severas da doença periodontal parece afetar uma minoria de individuos nos paises industrializados, em proporções que, provavelmente, não excedem a $10 \%$ ou $15 \%$ da população, e que, para idades abaixo de 30 anos, perdas médias minimas de inserção clínica são esperadas (níveis de inserção periodontal médios inferiores a um milímetro) (LÖE et al. ${ }^{56} 1978$ ), era esperado que as puérperas avaliadas neste estudo não tivessem expressivas perdas de inserção de tecido periodontal.

Embora vários estudos clinicos tenham sido realizados para avaliação da possível associação da doença periodontal com o nascer prematuro e de baixo peso, dentre os diversos autores compilados, muitas diferenças conceituais foram 
encontradas, não havendo unanimidade quanto à escolha dos parâmetros clínicos de avaliação para essa possivel associação, nem quanto ao grau de destruição tecidual determinante para tal.

Investigações clínicas distintas têm considerado, como fator de risco ao parto prematuro e ao baixo peso ao nascer, desde a ocorrência de valores de perda de inserção periodontal de pelo menos dois milímetros (OFFENBACHER et al. ${ }^{89} 2001$; MADIANOS et al. ${ }^{60} 2001$ ), até perdas de quatro milímetros ou mais (MOLITERNO et al. $^{73}$ 2002), e/ou valores de quatro a cinco milimetros durante a medição das profundidades de sondagem (LÓPEZ et al. ${ }^{57}$ 2002; MOORE et al. ${ }^{74,75}$ 2002a,b), afetando diferentes números de sitios (três ou mais, quatro ou mais, cinco ou mais sítios). Conseqüentemente, resultados discrepantes têm sido observados, provavelmente devido ao fato de esses estudos incluírem apenas pequeno número de participantes, grupos populacionais de pequena diversidade étnica e diferentes critérios de exposição materna à doença periodontal.

Pelo fato de LOURO et al. ${ }^{58}$ (2001), SILVA et al. ${ }^{110}(2001)$, MOLITERNO et al. ${ }^{73}$ (2002), em estudos epidemiológicos desenvolvidos no Brasil, respectivamente em Porto Alegre, Fortaleza e no Rio de Janeiro, e este estudo, desenvolvido em São Paulo, bem como outros estudos desenvolvidos nos Estados Unidos e Chile (OFFENBACHER et al ${ }^{86}$ 1996b; LÓPEZ et al ${ }^{57}$ 2002), terem utilizado diferentes parâmetros clinicos de avaliação, bem como terem estabelecido distintos limiares de exposição materna à doença periodontal, a possibilidade de comparação entre os resultados encontrados ficou inviabilizada.

Embora apenas 20 puérperas dentre as 174 avaliadas tenham referido tratamento periodontal ou previamente (18 puérperas) ou durante o último periodo 
gestacional ( 4 puérperas, sendo que 2 já haviam realizado tratamento periodontal também anteriormente ao último periodo gestacional) este estudo procurou avaliar o possivel efeito protetor do tratamento periodontal sobre resultados adversos na gravidez. Nenhuma associação significativa pôde ser confirmada, provavelmente pelo pequeno número de puérperas analisadas e pelo fato de esse tipo de variável ser melhor avaliada através da realização de estudos longitudinais. $\mathrm{O}$ tratamento periodontal, além de prevenir a progressão da perda de inserção dos tecidos de sustentação dental, bem como a sua recorrência, também otimiza, através da redução da infecção microbiana, o risco de liberação sistêmica de expressivas concentrações de bactérias, lipopolissacarídeos e diversos mediadores inflamatórios, dentre eles as citocinas IL-1 $\beta$, FNT $\alpha$, IL-6, as prostaglandinas, especialmente as PGE2, e as metaloproteinases da matriz extracelular, podendo desencadear, dessa forma, um efeito protetor contra resultados adversos na gravidez (OFFENBACHER e BECK ${ }^{87}$ 1998a).

Embora nas condições e com os critérios adotados neste estudo tenha sido possivel verificarr que a presença da doẹnça periodontal materna está associada ao parto prematuro e ao baixo peso ao nascer, a interpretação desse resultado deve ser feita com precaução até que dados obtidos de estudos longitudinais sejam apresentados. No entanto, se novos achados confirmarem essa associação, considerando que a doença periodontal é de fácil prevenção e, nos níveis em que foi observada nesta população, não apresenta dificuldade para tratamento, sua eliminação na gestante poderia promover a redução da ocorrência de muitos desfechos indesejáveis na gravidez, bem como da alta incidência de morbidade e mortalidade neonatal. 


\section{CONCLUSÕES}

A análise e discussão dos resultados permite concluir que:

1. Em ambos os grupos observa-se uma forma localizada e branda de destruição periodontal, uma vez que a perda de tecido periodontal de inserção nos sítios afetados e a proporção de sitios com sinais de doença periodontal destrutiva é levemente maior no grupo pré-termo (ESI $[12 ; 2,0]$ ) em relação ao grupo termo (ESI $[8 ; 1,9])$.

2. Há evidência estatística para aceitar associação significativa $(p=0,0133)$ entre a presença da doença periodontal e a ocorrência do nascer prematuro associado ao baixo peso.

3. Embora haja associação entre doença periodontal e condições desfavoráveis ao nascimento, na Análise de Regressão Logística Binomial apenas as variáveis "número de consultas pré-natais", "parto prematuro prévio" e "número de partos concluidos (sem o último)", constituíram-se em fatores de risco, uma vez que a doença periodontal não se manteve no modelo. 


\section{REFERÊNCIAS BIBLIOGRÁFICAS}

1. Almeida Filho N, Rouquayrol MZ. Introdução à epidemiologia moderna. $2^{\mathrm{a}}$. ed. Belo Horizonte, Salvador, Rio de Janeiro: COOPMED, APCE Produtos do conhecimento, ABRASCO; 1992.

2. Althabe O, Schwarcz R. Aspectos perinatales del parto prematuro. Buenos Aires: 1978.

3. Andrews WW, Goldenberg RL, Hauth JC. Preterm labor: emerging role of genital tract infections. Infect Agents Dis 1995a; 4:196-211.

4. Andrews WW, Hauth JC, Goldenberg RL, Gomez R, Romero R, Cassell GH. Amniotic fluid interleukin-6: correlation with upper genital tract microbial colonization and gestational age in women delivered after spontaneous labor versus indicated delivery. Am J Obstet Gynecol 1995b; 173:606-12.

5. Apgar. Annesth Analg 1953; 32:260-7.

6. Ballard $\mathrm{J}$, et al. New Ballard score, expanded to include extremely premature infants. J Pediatric 1991; 119:417-23.

7. Bejar R, Curbelo V, Davis C, Gluck L. Premature labor. II. Bacterial sources of phospholipase. Obstet Gynecol 1981; 57:479-82. 
8. Bennett PR, Rose MP, Myatt L, Elder MG. Preterm labor: stimulation of arachidonic acid metabolism in human amnion cells by bacterial products. Am $\mathbf{J}$ Obstet Gynecol 1987; 156:649-55.

9. Berkowitz GS, Papiernik E. Epidemiology of preterm birth. Epidemiol Rev 1993; $15: 414-43$.

10. Berkowitz K, LaSala A. Risk factors associated with the increasing prevalence of pneumonia during pregnancy. Am J Obstet Gynecol 1990; 163:981-5.

11. Bulmer JN, Johnson PM. Macrophage populations in the human placenta and amniochorion. Clin Exp Immunol 1984; 57:393-403.

12. Carlos JP, Wolfe MD, Kingman A. The extent and severity index: a simple method for use in epidemiologic studies of periodontal disease. $\mathbf{J}$ Clin Periodontol 1986; 13:500-5.

13. Casey ML, Cox SM, Beutler B, Milewich L, MacDonald PC. Cachectin tumor necrosis factor- $\alpha$ formation in human decidua. Potential role of cytokines in infection-induced preterm labor. J Clin Invest 1989; 83:430-6.

14. Chamberlain G. Epidemiologia e etiologia do recém-nascido pré-termo. Clínica Obstétrica e Ginecológica 1984; 11:309.

15. Collins JG, Windley HW, Arnold RR, Offenbacher S. Effects of a Porphyromonas gingivalis infection on inflammatory mediator response and pregnancy outcome in hamsters. Infect Immun 1994a; 62:4356-61. 
16. Collins JG, Smith MA, Arnold RR, Offenbacher S. Effects of Escherichia coli and Porphyromonas gingivalis lipopolysaccharide on pregnancy outcome in the golden hamster. Infect Immun 1994b; 62:4652-5.

17. Collins JG, Kirtland BC, Amold RR, Offenbacher S. Experimental periodontitis retards hamster fetal growth. J Dent Res 1995; 74 (Spec. Issue):158(Abstr. 1117).

18. Cotran RS, Kumar V, Robbins SL. Robbins patologia estrutural e funcional. Rio de Janeiro: 1996.

19. Cottone JA, Terezhalmy GT, Molinari JA. Practical infection control in dentistry. Philadelphia: 1991.

20. Craigo SD. Cervical incompetence and preterm delivery. N Engl J Med 1996; $334: 595-6$.

21. Creasy RK, Merkatz IR. Prevention of preterm birth: clinical opinion. Obstet Gynecol 1990; 76:2-4.

22. Cunningham FG, et al. Williams obstetrics. $21^{\text {a }}$. ed. New York: McGraw-Hill, 2001.

23. Damaré SM, Maynor G, Jenzano J, Katz V, Offenbacher S. Relationship between periodontal and amniotic fluid inflammatory mediators in pregnancy. $\mathbf{J}$ Dent Res 1995; 74:158(Abstr.1173). 
24. Damaré SM, Wells $S$, Offenbacher $S$. Eicosanoids in periodontal diseases: potential for systemic involvement. Adv Exp Med Biol 1997; 433:23-35.

25. Dasanayake AP. Poor periodontal health of the pregnant woman as a risk factor for low birth weight. Ann Periodontol 1998; 3:206-12.

26. Davenport ES, Williams CECS, Sterne JAC, Sivapathasundram V, Fearne JM, Curtis MA. The East London study of maternal chronic periodontal disease and preterm low birth weight infants: study design and prevalence data. Ann Periodontol 1998; 3:213-21.

27. Dean AG, Dean JA, Coulombier D, Brendel KA, Smith DC, Burton AH, et al. Epi Info (version 6.04). Atlanta: Centers for Disease Control and Prevention; 1997.

28. Dietrich JW, Goodson JM, Raisz LG. Stimulation of bone resorption by various prostaglandins in organ culture. Prostaglandins 1975; 10:231-8.

29. Dombroski RA, Woodard DS, Harper MJK, Gibbs RS. A rabbit model for bacteria-induced preterm pregnancy loss. Am J Obstet Gynecol 1990; $163: 1938-43$.

30. Forattini OP. Epidemiologia geral. São Paulo: USP, 1976.

31. Gibbs RS, Romero R, Hillier SL, Eschenbach DA, Sweet RL. A review of premature birth and subclinical infection. Am J Obstet Gynecol 1992; $166: 1515-28$. 
32. Gibbs RS. The relationship between infections and adverse pregnancy outcomes: an overview. Ann Periodontol 2001; 6:153-63.

33. Gierse JK, Hauser SD, Creely DP, Rangwala SH, Isakson PC, Seibert K. Expression and selective inhibition of the constitutive and inducible forms of human cyclo-oxygenase. Biochem J 1995; 305:479-84.

34. Goldenberg RL, Hauth JC, Andrews WW. Intrauterine infection and preterm delivery. N Engl J Med 2000; 342:1500-7.

35. Gomez R, Ghezzi F, Romero R, Munoz H, Tolosa JE, Rojas I. Premature labor and intra-amniotic infection. Clinical aspects and role of the cytokines in diagnosis and pathophysiology. Clin Perinatol 1995; 22:281-342.

36. Gravett MG, Nelson HP, DeRouen T, Critchlow C, Eschenbach DA, Holmes KK. Independent associations of bacterial vaginosis and Chlamydia trachomatis infection with adverse pregnancy outcome. JAMA 1986; 256:1899-1903.

37. Gravett MG, Witkin SS, Haluska GJ, Edwards JL, Cook MJ, Novy MJ. An experimental model for intraamniotic infection and preterm labor in rhesus monkeys. Am J Obstet Gynecol 1994; 171:1660-7.

38. Hannah ME, Ohlsson A, Wang EE, et al. Maternal colonization with group $B$ Streptococcus and pre-labor rupture of membranes at term: the role of induction of labor. Am J Obstet Gynecol 1997; 177:780-5. 
39. Hayashi J, Saito I, Ishikawa I, et al. Effects of cytokines and periodontopathic bacteria on the leukocyte function-associated antigen intercellular adhesion molecule 1 pathway in gingival fibroblasts in adult periodontitis. Infect Immun $1994 ; 62: 5205-12$.

40. Hillier SL, Witkin SS, Krohn MA, Watts DH, Kiviat NB, Eschenbach DA. The relationship of amniotic fluid cytokines and preterm delivery, amniotic fluid infection, histologic chorioamnionitis, and chorioamnion infection. Obstet Gynecol 1993; 81:941-8.

41. Hillier SL, Nugent RP, Eschenbach DA, et al. Association between bacterial vaginosis and preterm delivery of a low-birth-weight infant. The vaginal infections and prematurity study group. N Engl J Med 1995; 333:1737-42.

42. Hillmann G, Hillmann B, Geurtsen W. Immunohistological determination of interleukin-1 beta in inflamed human gingival epithelium. Arch Oral Biol 1995; 40:353-9.

43. Hoffman HJ, Bakketeig LS. Risk factors associated with the occurrence of preterm birth. Clin Obstet Gynecol 1984; 27:539.

44. Holst E, Goffeng AR, Andersch B. Bacterial vaginosis and vaginal microorganisms in idiopathic premature labor and association with pregnancy outcome. J Clin Microbiol 1994; 32:176-86. 
45. Ishida $\mathrm{H}$, Shinohara $\mathrm{H}$, Amabe $\mathrm{Y}$, et al. Effects of interleukin-1beta, tumor necrosis factor alpha and transforming growth factor beta on group II phospholipase A2 activity in rat gingival fibroblasts. J Periodont Res 1993; 28:517-20.

46. Jandinski JJ, Stashenko P, Feder LS, et al. Localization of interleukin-1 beta in human periodontal tissue. J Periodontol 1991; 62:36-43.

47. Jeffcoat MK, Geurs NC, Reddy MS, Goldenberg RL, Hauth JC. Current evidence regardind periodontal disease as a risk factor in preterm birth. Ann Periodontol $2001 ; 6: 183-88$.

48. Kramer MS. Determinants of low birth weight: methodological assessment and meta-analysis. Bull WHO 1987; 65:663-737.

49. Kullander S. Fever and parturition. An experimental study in rabbits. Acta Obstet Gynecol Scand 1977; 56(Suppl.66):77-85.

50. Lamont RF, Rose M, Elder MG. Effect of bacterial products on prostaglandin E production by amnion cells. The Lancet 1985.p.1331-3.

51. Lanning JC, Hilbelink DR, Chen LT. Teratogenic effects of endotoxin on the golden hamster. Teratog Carcinog Mutagen 1983; 3:145-9.

52. Leibovich SF, Polverini PIJ, Shepard HM, et al. Macrophage-induced angiogenesis is mediated by tumor necrosis factor alpha. Nature 1987; 329:630-2. 
53. Lindemann RA, Economou JS, Rothermel H. Production of interleukin-1 and tumor necrosis factor by human peripheral monocytes activated by periodontal bacteria and extracted lipopolysaccharides. J Dent Res 1988; 67:1131-5.

54. Lindhe J. Tratado de periodontia clínica e implantologia oral. Rio de Janeiro: Guanabara-Koogan, $1999^{2}$.

55. Lindhe J. Tratado de periodontia clínica e implantologia oral. Rio de Janeiro: Guanabara-Koogan,1999b.

56. Löe H, Ånerud $\AA$, Boysen H, Smith M. The natural history of periodontal disease in man. Study design and baseline data. J Periodont Res 1978; 13:550-62.

57. López NJ, Smith PC, Gutierrez J. Higher risk of preterm birth and low birth weight in women with periodontal disease. $\mathbf{J}$ Dent Res 2002; 81:58-63.

58. Louro PM, Fiori HH, Louro Filho P, Fiori RM. Doença periodontal na gravidez e baixo peso ao nascer. J Pediatr 2001; 77:23-8.

59. Məller M, Borch K, Thomsen AC, Dinesen K, Zdravkovic M. Rupture of fetal membranes and premature delivery associate with group $B$ streptococci in urine of pregnant women. The Lancet: 1984.p.69-70.

60. Madianos PN, Lieff S, Murtha AP, Boggess KA, Auten Jr. RL, Beck JD, Offenbacher S. Maternal periodontitis and prematurity. Part II: maternal infection and fetal exposure. Ann Periodontol 2001; 6:175-82 
61. Main DM. The epidemiology of preterm birth. Clin Obstet Gynecol 1988; $31: 521$.

62. Marcondes E. Pediatria básica. $7^{\text {a }}$. ed. São Paulo: Sarvier, 1986.

63. Masada MP, Persson R, Kenny JS, Lee SW, Page RC, Allison AC. Measurement of interleukin- $1 \alpha$ and $1-\beta$ in gingival crevicular fluid: implications for the pathogenesis of periodontal disease. J Periodont Res 1990; 25:156-63.

64. Matsuki Y, Yamamoto T, Hara K. Localization of interleukin-1 (L-1) mRNAexpressing macrophages in human inflamed gingival and $\mathbb{L}-1$ activity in gingival crevicular fluid. J Periodont Res 1993; 28:35-42.

65. Mazor M, Wiznitzer A, Mlymon E, Leiberman JR, Cohen A. Changes in amniotic fluid concentrations of prostaglandins E2 and F2 in women with preterm labor. Isr J Med Sci 1990; 26:425-8.

66. McDuffie RS Jr, Sherman MP, Gibbs RS. Amniotic fluid tumor necrosis factor- $\alpha$ and interleukin-1 in a rabbit model of bacterially induced preterm pregnancy loss. Am J Obstet Gynecol 1992; 167:1583-88.

67. McKay DG, Wong T-C. The effect of bacterial endotoxin on the placenta of the rat. Am J Pathol 1963: 42:357-77. 
68. Meis PJ, Goldenberg RL, Mercer B, et al. and the National Institute of Child Health and Human Development Maternal-Fetal Medicine Units Network. The preterm prediction study: significance of vaginal infections. Am J Obstet Gynecol 1995; 173:1231-35.

69. Ministério da Saúde. Manual técnico de assistência pré-natal. Brasília: MS; 2000 .

70. Minkoff H, Grunebaum AN, Schwarz RH, et al. Risk factors for prematurity and premature rupture of membranes: a prospective study of the vaginal flora in pregnancy. Am J Obstet Gynecol 1984; 150:965-72.

71. Mitchell MD, Dudley DJ, Edwin SS, Schiller SL. Interleukin-6 stimulates prostaglandin production by human amnion and decidual cells. Eur J Pharmacol $1991 ; 192: 189-91$.

72. Mitchell-Lewis D, Engebretson SP, Chen J, Lamster IB, Papapanou PN. Periodontal infections and pre-term labor: early findings from a cohort of young minority women in New York. Eur J Oral Sci 2001; 109:34-9.

73. Moliterno LFM, Miranda LA, Fischer RG. Association between periodontitis and preterm low birth weight infants. Disponivel em: http:/iadr.confex.com/iadr/2002SanDiego/te.../abstract_20312.ht. Acesso em 03/04/02. 
74. Moore S, Ide M, Wilson RF, Randhawa M, Coward PY, Borkowska E, Baylis R, GKT Dental Institute. Disponível em: http://iadr.confex.com/iadr/2002SanDiego/te.../abstract 15704.ht. Acesso em 03/04/02. (a)

75. Moore S, I de M, Wilson RF, Randhawa M, Coward PY, Borkowska E, Baylis R, GKT Dental Institute. Disponível em: http://iadr.confex.com/iadr/2002SanDiego/te.../abstract_15595.ht. Acesso em 03/04/02. (b)

76. Morrison JC. Preterm birth: a puzzle worth solving. Obstet Gynecol 1990; 76:512.

77. Nakashima K, Roerich N, Cimasoni G. Osteocalcin, prostaglandin E2 and alkaline phosphatase in gingival crevicular fluid: their relations to periodontal status. J Clin Periodontol 1994; 21:327-33.

78. Neme B. Obstetrícia básica. $2^{\text {a }}$. ed. São Paulo: Sarvier, 2000.

79. Noack B, Wachter I, Hoffmann T, Dresden TU. Periodontal status and pregnancy outcomes in a German population. Disponivel em: http://iadr.confex.com/iadr/2002SanDiego/te.../abstract 9620.ht. Acesso em 03/04/02. 
80. Offenbacher S, Farr DH, Goodson JM. Measurement of prostaglandin E in crevicular fluid. J Clin Periodontol 1981; 8:359-367.

81. Offenbacher S, Odle BM, Gray RC, Van Dyke TE. Crevicular fluid prostaglandin E levels as a mesure of the periodontal disease status of adult and juvenile periodontitis patients. J Periodont Res 1984; 19:1-13.

82. Offenbacher S, Odle BM, Van Dyke TE. The use of crevicular fluid prostaglandin E2 levels as a predictor of periodontal attachment loss. $\mathbf{J}$ Periodont Res 1986; 21:101-12.

83. Offenbacher S, Williams RC, Jeffcoat MK, Howell TH, Odle BM, Smith MA, Hall CM, Johnson HG, Goldhaber P. Effects of NSAIDs on beagle crevicular cyclooxigenase metabolites and periodontal bone loss. J Periodont Res 1992; 27:207-13.

84. Offenbacher S, Heasman PA, Colllins JG. Modulation of host PGE2 secretion as a determinant of periodontal disease expression. J Periodontol 1993; 64:432-44.

85. Offenbacher S. Periodontal diseases: pathogenesis. Ann Periodontol 1996a; 1:821-78.

86. Offenbacher S, Katz V, Fertik G, Collins J, Boyd D, Maynor G, McKaig R, Beck J. Periodontal infection as a possible risk factor for preterm low birth weight. $\mathbf{J}$ Periodontol 1996b; 67:1103-13. 
87. Offenbacher S, Beck JD. Periodontite: um fator de risco potencial para nascimento prematuro. Aspectos periodontais e saúde sistêmica. I Simpósio Internacional de Medicina Bucal. São Paulo; 1998a.p.39-49. Material desenvolvido para Simpósio patrocinado pela Colgate-Palmolive Company.

88. Offenbacher S, Jared HL, O'Reilly PG, Wells SR, Salvi GE, Lawrence HP, Socransky SS, Beck JD. Potential pathogenic mechanisms of periodontitisassociated pregnancy complications. Ann Periodontol 1998b; 3:233-50.

89. Offenbacher S, Lieff S, Boggess KA, Murtha AP, Madianos PN, Champagne CME, McKaig RG, Jared HL, Mauriello SM, Auten Jr. RL, Herbert WNP, Beck JD. Maternal periodontitis and prematurity. Part I: obstetric outcome of prematurity and growth restriction. Ann Periodontol 2001; 6:164-74.

90. Page RC. The role of inflammatory mediators in the pathogenesis of periodontal disease. J Periodont Res 1991; 26:230-42.

91. Page RC. The pathobiology of periodontal diseases may affect systemic diseases: inversion of a paradigm. Ann Periodontol 1998; 3:108-20.

92. Rêgo MAV. Aspectos históricos dos estudos caso-controle. Caderno Saúde Pública 2001; 17:1017-24.

93. Rezende J de. Obstetrícia. 7a. ed. Rio de Janeiro: Guanabara-Kooga, 1995. 
94. Richards D, Rutherford RB. The effects of interleukin-1 on collagenolytic activity and prostaglandin E secretion by human periodontal ligament and gingival fibroblast. Arch Oral Biol 1988; 33:237-43.

95. Rieder RF, Thomas L. Studies on the mechanisms involved in the production of abortion by endotoxin. J Immunol 1960; 84:189-93.

96. Rifkin BR, Baker RL, Coleman SJ. Effects of prostaglandin E2 on macrophages and osteoclasts in cultured foetal long bones. Cell Tissue Res 1980; 207:341-6.

97. Romero R, Quintero R, Emamian M, et al. Arachidonate lipoxygenase metabolites in amniotic fluid of women with intra-amniotic infection and preterm labor. Am J Obstet Gynecol 1987; 157:1454-60.

98. Romero R, Mazor M. Infection and preterm labor. Clin Obstet Gynecol 1988a; 31:553-84.

99. Romero R, Wu YK, Mazor M, Hobbin JC, Mitchell MD. Amniotic fluid PGE2 in preterm labor. Prostaglandins Leukot Essent Fatty Acids 1988b; 34:141-5

100. Romero R, Sirtori M, Oyarzun E, et al. Infection and labor. V. Prevalence, microbiology, and clinical significance of intraamniotic infection in women with preterm labor and intact membranes. Am J Obstet Gynecol 1989: 161:817-24.

101. Romero R, Avila C, Santhanam U, Sehgal PB. Amniotic fluid interleukin-6 in preterm labor. Association with infection. J Clin Invest 1990; 85:1392-1400. 
102. Romero R, Yoon BH, Mazor M, Gomez R, et al. The diagnostic and prognostic value of amniotic fluid white blood cell count, glucose, interleukin-6, and Gram stain in patients with preterm labor and intact membranes. Am J Obstet Gynecol $1993 ; 169: 805-16$

103. Romero R, Muñoz H, Gomez R, et al. Two thirds of spontaneous abortion/fetal deaths after genetic midtrimester amniocentesis are the result of a pre-existing subclinical inflammatory process of the amniotic cavity. Am J Obstet Gynecol $1995 ; 172: 261$ (Abstr.24).

104. Rouquayrol MZ. Epidemiologia e saúde. UNIFOR - Universidade de Fortaleza (Fundação Educacional Edson Queiroz) 1983.

105. Rush RW et al. Contribution of preterm delivery to perinatal mortality. Brit Med J 1976; 2:965.

106. SAS (version 8.0). Cary: SAS Institute INC; 1998.

107. SEADE - Fundação Sistema Estadual de Análise de Dados. Anuário Estatístico do Estado de São Paulo. São Paulo: 1994.

108. Seibert K, Masferrer JL. Role of inducible cyclooxygenase (COX-2) in inflammation. Receptor 1994; 4:17-23.

109. Seymour GJ, Gemmell E, Reinhardt RA, et al. Immunopathogenesis of chronic inflammatory periodontal disease: cellular and molecular mechanisms. $\mathbf{J}$ Periodont Res 1993; 28:478-86. 
110. Silva APB, Bretz WA, Mendes M, Soares A, Loesche WJ. Periodontal infections and pre-term low birth weight. Disponivel em: http:/iadr.confex.com/iadr/200.../schedulerpaper.cgi?abstract=319 Acesso em 03/04/02.

111. Sims JE, March CJ, Cosman D, et al. cDNA expression cloning of the IL-1 receptor, a member of the immunoglobulin superfamily. Science 1988; 241:5859.

112. Siqueira Jr JF, Dantas CJS. Mecanismos celulares e moleculares da inflamação. Rio de Janeiro: Medsi, 2000.

113. Skarnes RC, Harper MJK. Relationship between endotoxin-induced abortion and the synthesis of prostaglandin F. Prostaglandins 1972; 1:191-203.

114. Sobel JD. Bacterial vaginosis. Annu Rev Med 2000; 51:349-56.

115. Souza E, Santos JFK, Bancher MM, Bertini AM, Camano L. Considerações sobre a prematuridade eletiva na Universidade Federal de São Paulo- Escola Paulista de Medicina. RBGO 1995; 17:583-9.

116. Stashenko P, Dewhirst FE, Peros WJ, Kent RL, Apo JM. Synergistic interactions between interleukin-1, tumor necrosis factor and lymphotoxin in bone resorption. J Immunol 1987; 138:1464-8.

117. Stublefield PG. Causes and prevention of preterm birth: an overview. Preterm birth: causes, prevention and management. New York; 1984.p.6. 
118. Takahashi $\mathrm{K}$, Takigawa $\mathrm{M}$, Takashiba $\mathrm{S}$, et al. Role of cytokine in the induction of adhesion molecules on cultured human gingival fibroblasts. J Periodontol $1994 ; 65: 230-5$

119. Takeda Y, Tsuchiya I. Studies on the pathological changes caused by the injection of the Shwartzman filtrate and the endotoxin into pregnant rabbits. Jpn J Exper Med 1953; 23:9-16a.

120. Takeda Y, Tsuchiya I. Studies on the pathological changes caused by the injection of the Shwartzman filtrate and the endotoxin into pregnant rabbits. II. On the relationship of the constituents of the endotoxin and the abortionproducing factor. Jpn J Exper Med 1953; 23:105-10b.

121. Williams RC. Doença periodontal: o surgimento de um novo paradigma. Aspectos periodontais e saúde sistêmica. I Simpósio Internacional de Medicina Bucal. São Paulo; 1998a.p.1-10. Material desenvolvido para Simpósio patrocinado pela Colgate-Palmolive Company.

122. Williams TJ, Peck MJ. Role of prostaglandin-mediated vasodilation in inflammation. Nature $1977 ; 270: 530-2$.

123. Young IR, Deayton JM, Hollingworth SA, Thorbum GD. Continuous intrafetal infusion of prostaglandin E2 prematurely activates the hypothalamo-pituitaryadrenal axis and induces parturition in sheep. Endocrinology 1996; 137:2424-31 


\section{Anexo 1}

Ficha para entrevista inicial

Universidade de São Paulo

Faculdade de Saúde Pública

\begin{tabular}{|c|c|c|c|}
\hline \multicolumn{2}{|l|}{ Nome: } & \multicolumn{2}{|l|}{ RGH: } \\
\hline \multicolumn{2}{|c|}{ HSP ( ) HVM ( ) HI（） Data da entrevista: } & Data do parto: & $0: \quad 1$ \\
\hline \multicolumn{2}{|l|}{ Parto pré-termo ( ) } & \multicolumn{2}{|c|}{ Parto a termo ( ) } \\
\hline \multicolumn{4}{|c|}{ História médica e obstétrica: } \\
\hline HIV & $\operatorname{Sim}()$ & Não ( ) & $\mathrm{Ns} / \mathrm{Nr}()$ \\
\hline Malformação fetal maior & $\operatorname{Sim}()$ & Não ( ) & $\mathrm{Ns} / \mathrm{Nr}($ \\
\hline Gestação múltipla & $\operatorname{Sim}()$ & Não（） & $\mathrm{Ns} / \mathrm{Nr}($ \\
\hline Malformação uterina & $\operatorname{Sim}()$ & Não ( ) & $\mathrm{Ns} / \mathrm{Nr}($ \\
\hline Interrupção eletiva da gestação & $\operatorname{Sim}()$ & Não（） & $\mathrm{Ns} / \mathrm{Nr}($ \\
\hline Óbito fetal & $\operatorname{Sim}()$ & Não( ) & $\mathrm{Ns} / \mathrm{Nr}($ \\
\hline Insuficiência istmica- cervical & $\operatorname{Sim}()$ & Não( ) & $\mathrm{Ns} / \mathrm{Nr}($ \\
\hline Descolamento prematuro da placenta & $\operatorname{Sim}()$ & Não ( ) & $\mathrm{Ns} / \mathrm{Nr}($ \\
\hline Problemas cardiacos & $\operatorname{Sim}()$ & Não( ) & $\mathrm{Ns} / \mathrm{Nr}($ \\
\hline Reumatismo infeccioso & $\operatorname{Sim}()$ & Não( ) & $\mathrm{Ns} / \mathrm{Nr}($ \\
\hline HPV & $\operatorname{Sim}()$ & Não( ) & $\mathrm{Ns} / \mathrm{Nr}($ \\
\hline Isoimunização Rh & $\operatorname{Sim}()$ & Não ( ) & $\mathrm{Ns} / \mathrm{Nr}($ \\
\hline Lupus eritematoso sistêmico & $\operatorname{Sim}()$ & Não( ) & $\mathrm{Ns} / \mathrm{Nr}($ \\
\hline Idade $<17$ ou $>35$ anos & $\operatorname{Sim}()$ & Não( ) & $\mathrm{Ns} / \mathrm{Nr}($ \\
\hline
\end{tabular}




\section{Anexo 2}

Ficha para consulta inicial ao prontuário hospitalar

Universidade de São Paulo

Faculdade de Saúde Pública

\begin{tabular}{|c|c|c|c|}
\hline \multicolumn{2}{|l|}{ Nome: } & \multicolumn{2}{|c|}{ GH: } \\
\hline HSP ( ) HVM ( ) HI ( ) Data da entrevista: & 11 & Data do $\mathrm{p}$ & to: $1 /$ \\
\hline \multicolumn{2}{|l|}{ Parto pré-termo（ ) } & \multicolumn{2}{|c|}{ Parto a termo ( ) } \\
\hline \multicolumn{4}{|c|}{ História médica e obstétrica: } \\
\hline HIV & $\operatorname{Sim}()$ & Não（ ) & S/inf. ( ) \\
\hline Malformação fetal maior & $\operatorname{Sim}()$ & Não ( ) & S/inf. ( ) \\
\hline Gestação múltipla & $\operatorname{Sim}(\quad)$ & Não( ) & S/inf. ( ) \\
\hline Malformação uterina & $\operatorname{Sim}()$ & Não ( ) & S/inf. ( ) \\
\hline Interrupção eletiva da gestação & $\operatorname{Sim}()$ & Não（ ） & S/inf. ( ) \\
\hline Óbito fetal & $\operatorname{Sim}()$ & Não（ ） & S/inf. ( ) \\
\hline Insuficiência ístmica-cervical & $\operatorname{Sim}()$ & Não( ) & S/inf. ( ) \\
\hline Descolamento prematuro da placenta & $\operatorname{Sim}()$ & Não( ) & S/inf. ( ) \\
\hline Problemas cardíacos & $\operatorname{Sim}()$ & Não（ ） & S/inf. ( ) \\
\hline Reumatismo infeccioso & $\operatorname{Sim}()$ & Não（ ) & S/inf. ( ) \\
\hline HPV & $\operatorname{Sim}()$ & Não ( ) & S/inf. ( ) \\
\hline Isoimunização Rh & $\operatorname{Sim}()$ & Não ( ) & S/inf. ( ) \\
\hline Lupus eritematoso sistêmico & $\operatorname{Sim}()$ & Não ( ) & S/inf. ( ) \\
\hline Idade $<17$ ou $>35$ anos & $\operatorname{Sim}()$ & Não（ ) & S/inf. ( ) \\
\hline $\begin{array}{l}\text { New Ballaard: } \\
\text { Apgar: } \\
\\
\text { IG: }\end{array}$ & apurro: & & \\
\hline
\end{tabular}




\section{Anexo 3 \\ Termo de consentimento informado \\ Universidade de São Paulo \\ Faculdade de Saúde Pública}

Declaro que fui entrevistada pela Dra. Maria Christina Brunetti, que me convidou a participar do estudo sobre avaliação da doença periodontal como fator de risco ao parto prematuro.

\section{A Dra. Christina me explicou:}

1) que eu serei submetida a uma nova entrevista e a um exame periodontal que tem como finalidade identificar as puérperas que apresentam infecção gengival;

2) a entrevista será feita verbalmente pelo próprio pesquisador e eu poderei responder apenas as perguntas que eu desejar;

3) o exame periodontal será realizado no próprio leito hospitalar, com duração aproximada de 15 minutos, pelo próprio pesquisador. O exame provocará o mínimo desconforto, sem provocar danos à minha saúde;

4) não sou obrigada a participar desse estudo, sendo que minha recusa não levará a qualquer prejuízo na continuidade da assistência pós-natal;

5) mesmo tendo aceitado participar do estudo, poderei a qualquer momento voltar atrás de minha decisão e abandoná-lo.

Esse documento foi lido pela Dra. Maria Christina Brunetti que me esclareceu as dưvidas e minha assinatura indica que concordei em participar do estudo.

Data: 1

Nome: RG:

\section{Assinatura da voluntária}

Eu certifico que expliquei todos os passos do documento acima, bem como os riscos e beneficios da participação na pesquisa.

Maria Christina Brunetti 


\section{Anexo 4}

\section{Ficha de pesquisa avançada}

Universidade de São Paulo

Faculdade de Saúde Pública

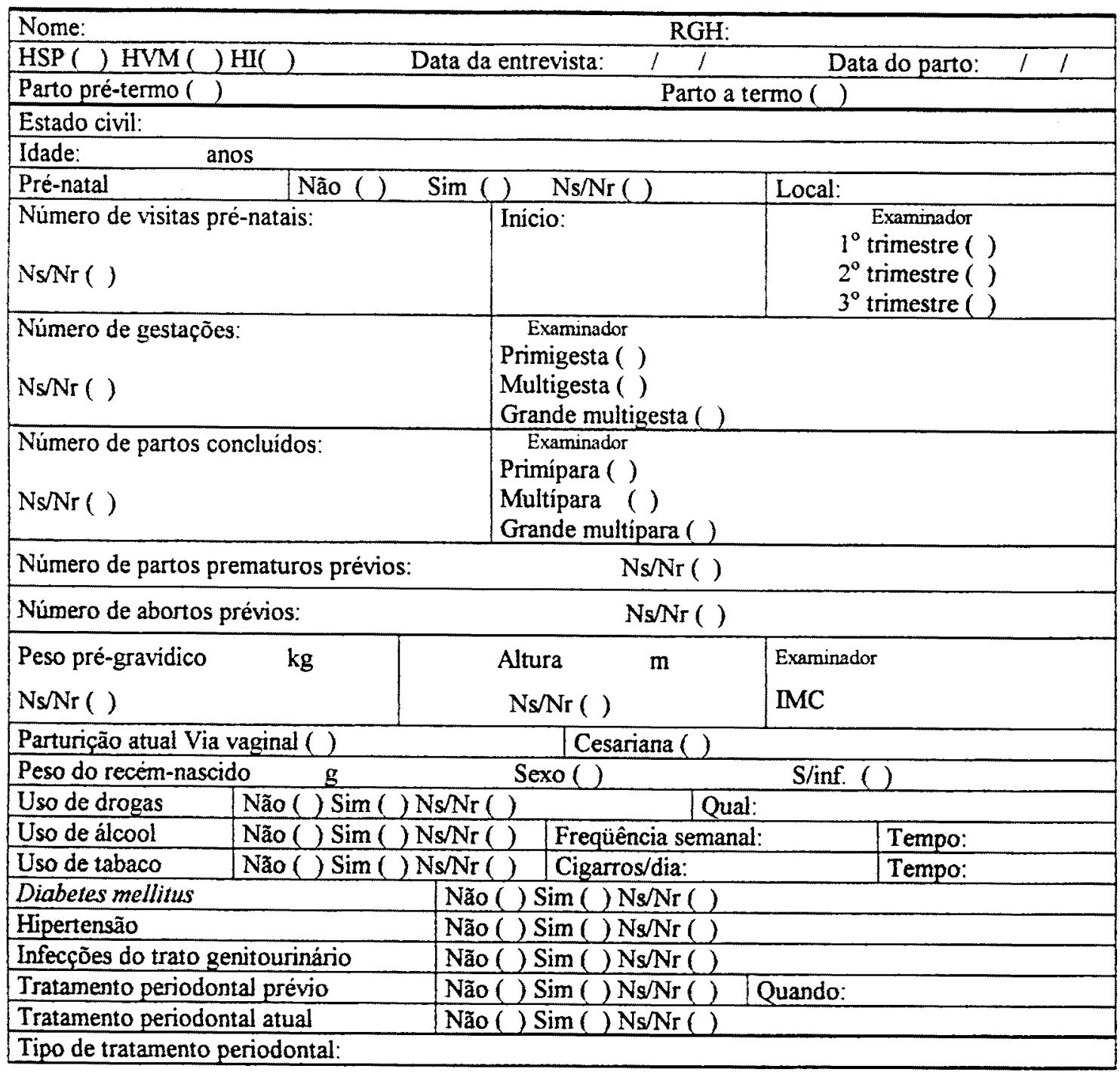


continuação do anexo 4

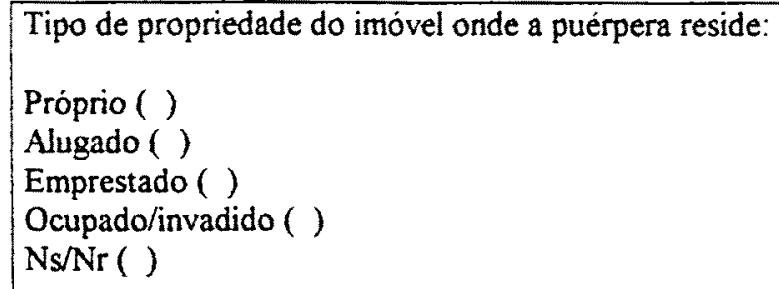




\section{Anexo 5}

Ficha para consulta avançada ao prontuário hospitalar

Universidade de São Paulo

Faculdade de Saúde Pública

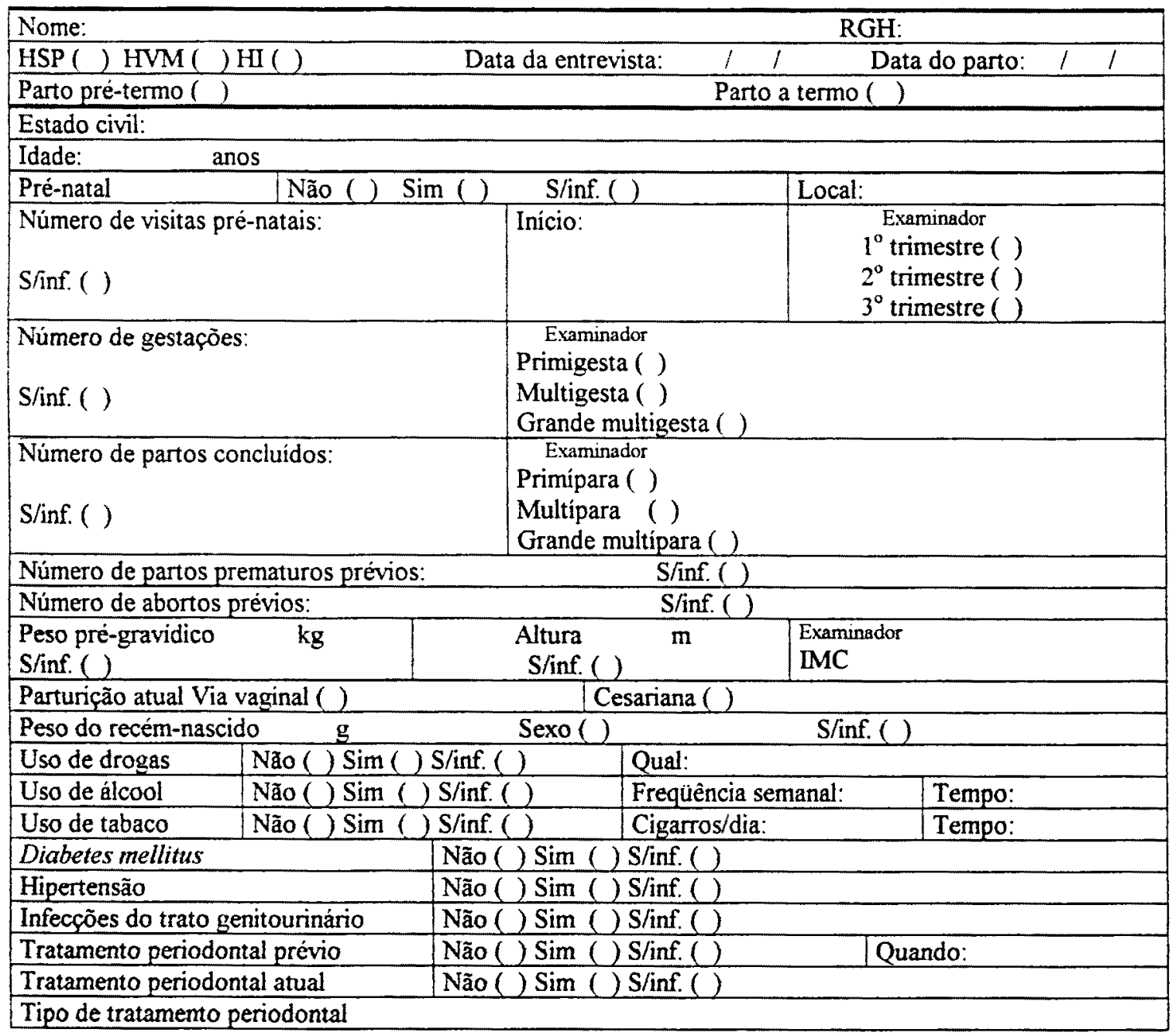

continua.. 
continuação do anexo 5

Tipo de propriedade do imóvel onde a puerpera reside:

Próprio ( )

Alugado ( )

Emprestado ( )

Ocupado/invadido ( )

S/inf. ( )

Caracteristica do espaço urbano onde a puérpera reside:

Casa ( )

Apto. ( )

Barraco ( )

Morador de rua ( )

Sinf. ()

Materiais predominantes no imóvel onde a puérpera reside:

Alvenaria ( )

Madeira ( )

Outros ( )

S/inf. ( )

Ocupação da puérpera:

Trabalhador registrado ( )

Trabalhador autônomo ( )

Trabalhador eventual ( )

S/atividade definida ( )

Desempregado ( )

Estudante ( )

Aposentado ( )

Dona de casa ( )

S/inf. ( )

Escolaridade da puérpera:

Analfabeta ( )

$1^{\circ}$ grau incompleto ( )

$1^{\circ}$ grau completo ( )

$2^{\circ}$ grau incompleto ( )

$2^{\circ}$ grau completo ( )

Superior incompleto ( )

Superior completo ( )

S/inf. ( )

Renda familiar: 


\section{ANEXO 6}

Ficha para registro periodontal

(medida em mm do nivel de inserção)

Universidade de São Paulo

Faculdade de Saúde Pública

\begin{tabular}{|c|c|c|c|c|c|c|c|}
\hline Nome: & & & & & & $\mathrm{RGI}$ & \\
\hline $\mathrm{HSP}()_{1}$ & $\mathrm{MC}$ & ( ) & & Data & $0:$ & 1 & \\
\hline Parto pré-t & no ( & & & & & tern & \\
\hline Data do ex & & & & & & & \\
\hline Dente & 11 & 12 & 13 & 14 & 15 & 16 & 17 \\
\hline Face & & & & & & & \\
\hline MSV & & & & & & & \\
\hline MDV & & & & & & & \\
\hline Dente & 37 & 36 & 35 & $\overline{34}$ & 33 & 32 & $\overline{31}$ \\
\hline Face & & & & & & & \\
\hline $\mathrm{MDV}$ & & & & & & & \\
\hline MSV & & & & & & & \\
\hline & & & & & & & \\
\hline
\end{tabular}


São Paulo, 07 de abril de 2000.

Ao Departamento de Prática de Saúde Pública

Faculdade de Saúde Pública - Universidade de São Paulo

Prof. Dr. Paulo Capel Narvai

Prezado Doutor

Venho por meio desta comunicar a aceitação da doutoranda Maria Christina Brunetti para trabalhar em conjunto ao Departamento de Tocoginecologia - Disciplina de Obstetrícia da Universidade Federal de São Paulo - Escola Paulista de Medicina, examinando puérperas no Hospital São Paulo e Hospital Municipal Vereador José Storópoli ( Hospital Vila Maria), para desenvolvimento do projeto intitulado "A infecção periodontal e o parto pré-termo".

Contando com sua colaboração, antecipadamente agradeço.

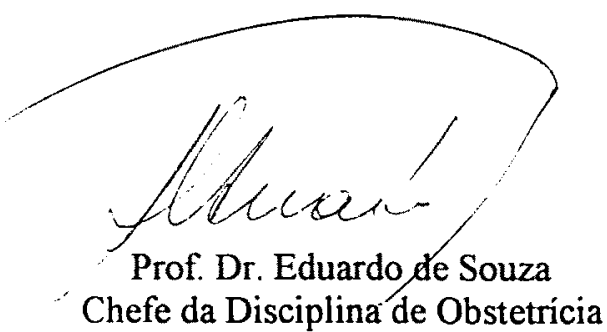

UNIFESP - EPM 
Prezada senhora,

Em resposta ao seu ofício de 27/03/2000, temos a informar que a clínica odontológica da FOUSP está aberta à comunidade da região, para triagem com vistas a tratamento odontológico. A triagem é uma atividade da Disciplina de Semiologia, sendo agendada dentro das possibilidades de vagas e a prioridade de atenção é para os pacientes moradores da regiāo. As vagas remanescentes, quando possível, são oferecidas à comunidade em geral, bastando, para isso, que o paciente procure o Ambulatório da FOUSP, nos baixos do Hospital Universitário, à Av. Prof. Lineu Prestes, 2565 Cidade universitária.

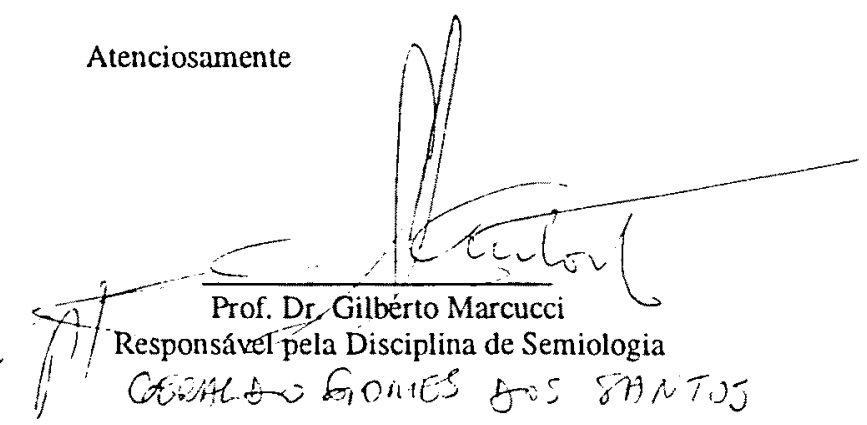

As Prof. Lincu Prestes. 2227 - Cidade Universitária "Armando de Salles Oliveira" CEP 05508-900 São Paulo - SP FAX (0i1) 814.9281 - TELEX (011) 36950 - Tels PABX (011) 813.694 Dirctoria (011) 8140062 - Contabilidade/Compras (011)814.9281 Impresso no S 1) ( ) 
ANEXO 9

A11

Para chustinc Buncetei

APCD tern surice de atendimento gratuito ao

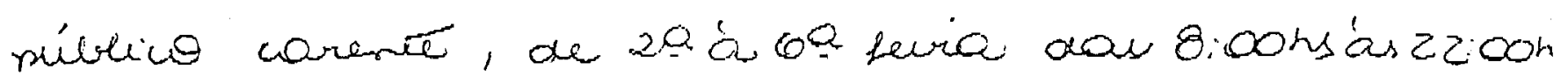

Enderez: Praca campo de Bagatelle, soo. Santana Tel: 62213022 ramal 245

Padenao assim, serem encaminadod nara cá, racientes carentes nara atendimento de emenséncea

PRONTO SOCORRO 


\title{
GLOSSÁRIO
}

\begin{abstract}
Aborto:
Definido segundo a Organização Mundial de Saúde (OMS) como a expulsão ou extração de feto ou embrião que pese menos de 500 gramas (idade gestacional de aproximadamente 20-22 semanas completas ou de 140-154 dias completos) ou de qualquer outro produto da gestação de qualquer peso e especificamente designado, independentemente da idade gestacional, tenha ou não sinal de vida e seja ou não espontâneo ou induzido.
\end{abstract}




\section{Apgar:}

Annesth Analg 1953; 32:260-7 (Ref. 5)

Boletim de Apgar

Aplicar com um e cinco minutos de vida do recém-nascido.

Sinal

Freqüência

cardíaca

Esforço

respiratório

Tônus muscular

Irritabilidade

(estímulo nasal)

Cor
0

1

Ausente

Menos de 100

batimentos por

minuto

Ausente

Irregular

Flacidez total

Alguma reflexão de extremidades

Ausente

Cianose ou palidez

cutânea
2

Mais de 100

batimentos por

minuto

Regular
Alguma reação Espirros

Corpo róseo e Corpo róseo

extremidades

cianóticas 


\section{Capurro:}

Marcondes E. Pediatria Bāsica. Brasili; 1986.p.336. (Ref. 62)

Método de Capurro (somático e neurológico)

\begin{tabular}{llrr}
\hline FORMA DA ORELHA & 0 & 8 & 16 \\
TEXTURA DA PELE & 0 & 5 & 24 \\
GLANDULA MAMARIA & 0 & 5 & 10 \\
PREGAS PLANTARES & 0 & 10 & 15 \\
SINAL DO XALE & 0 & 15 \\
POSIÇAO DA CABEÇA AO LEVANTAR O RN & 0 & 10 \\
\hline
\end{tabular}

$K=200$

$K+$ soma de pontos $=$ idade gestacional em dias (desvio-padrão \pm 8.4 dias)

$0=$ muito fina, gelatinosa

Textura da pele

5 = fina e lisa

$10=$ algo mais grossa, discreta descamação superficial

15 = grossa, rugas superficiais, descamaçăo nas mãos e pés

20 = grossa apergaminhada, com grutas profundas

Forma da orelha

$0=$ chata, disforme, pavilhão não encurvado

8 = pavilhão parcialmente encurvado na borda

16 = pavilhāo parcialmente encurvado em toda parte superior

24 = pavilhão totalmente encurvado

0 = não palpável

Glândula mamária

5 = palpável, menos de $5 \mathrm{~mm}$

$10=$ entre 5 e $10 \mathrm{~mm}$

$15=$ maior de $10 \mathrm{~mm}$

\section{Pregas plantares}

$0=$ sem pregas

$5=$ marcas mal definidas sobre a parte anterior da planta

$10=$ marcas bem definidas sobre a metade anterior e sulcos no terço anterior

15 = sulcos na metade anterior da planta

20 = sulcos em mais da metade anterior da planta

\section{Sinal do xale}

$0=0$ cotovelo alcança a linha axilar anterior do lado oposto

$6=0$ cotovelo situado entre a linha axilar anterior do lado oposto e a linha média

$12=0$ cotovelo situado ao nivel da linha média

18 = o cotovelo situado entre a linha média e a linha axilar anterior do mesmo lado

Posição da cabeça ao levantar o RN

$0=$ cabeça totalmente deflexionada, ângulo torácico $270^{\circ}$

4 = ângulo cérvico-torácico entre $180^{\circ}$ e $270^{\circ}$

8 = ângulo cérvico-torácico igual a $180^{\circ}$

12 = ângulo cérvico-torácico menor de $180^{\circ}$

$0=$ apenas visivel

\section{Formação do mamilo}

5 = aréola pigmentada - diâmetro menor que $75 \mathrm{~mm}$

10 = aréola pigmentada, ponteaguda $=$ diâmetro menor que $75 \mathrm{~mm}$, borda não levantada

15 = borda levantada - diâmetro maior que $75 \mathrm{~mm}$

Método de Capurro (somático)

\begin{tabular}{|c|c|c|c|c|c|}
\hline $\begin{array}{l}\text { TEXTURA DA PELE } \\
\text { FORMA DA ORELHA } \\
\text { GLANDULA MAMARIA } \\
\text { FORMACGAO DO MAMILO } \\
\text { PREGAS PLANTARES }\end{array}$ & $\begin{array}{l}0 \\
0 \\
0 \\
0 \\
0\end{array}$ & $\begin{array}{l}5 \\
8 \\
5 \\
5 \\
5\end{array}$ & $\begin{array}{l}10 \\
16 \\
10 \\
10 \\
10\end{array}$ & $\begin{array}{l}15 \\
24 \\
15 \\
15 \\
15\end{array}$ & 20 \\
\hline
\end{tabular}

$K=207$

$K+$ soma de pontos = idade gestacional em dias

Desvio-padrāo \pm 8.4 dias 


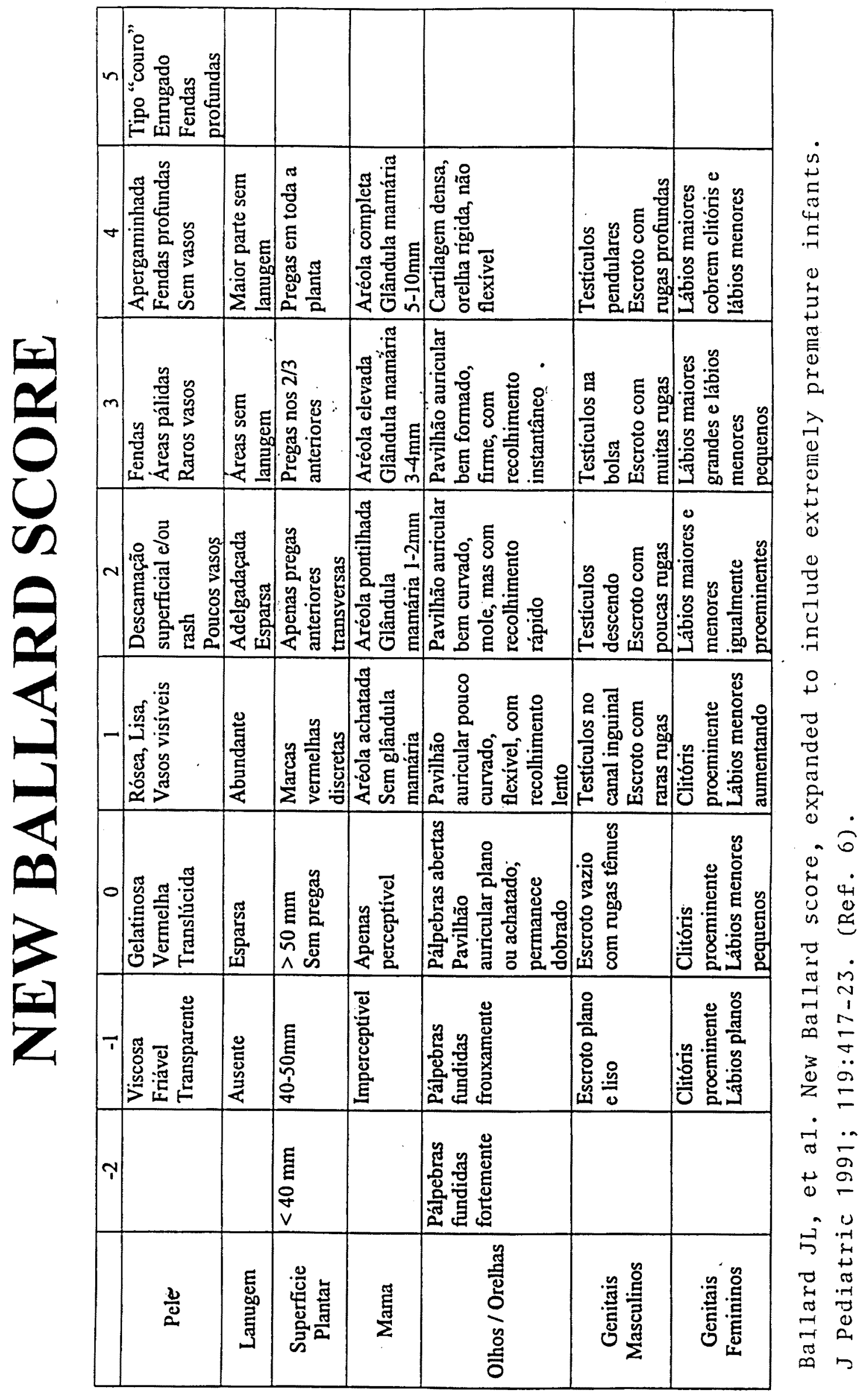




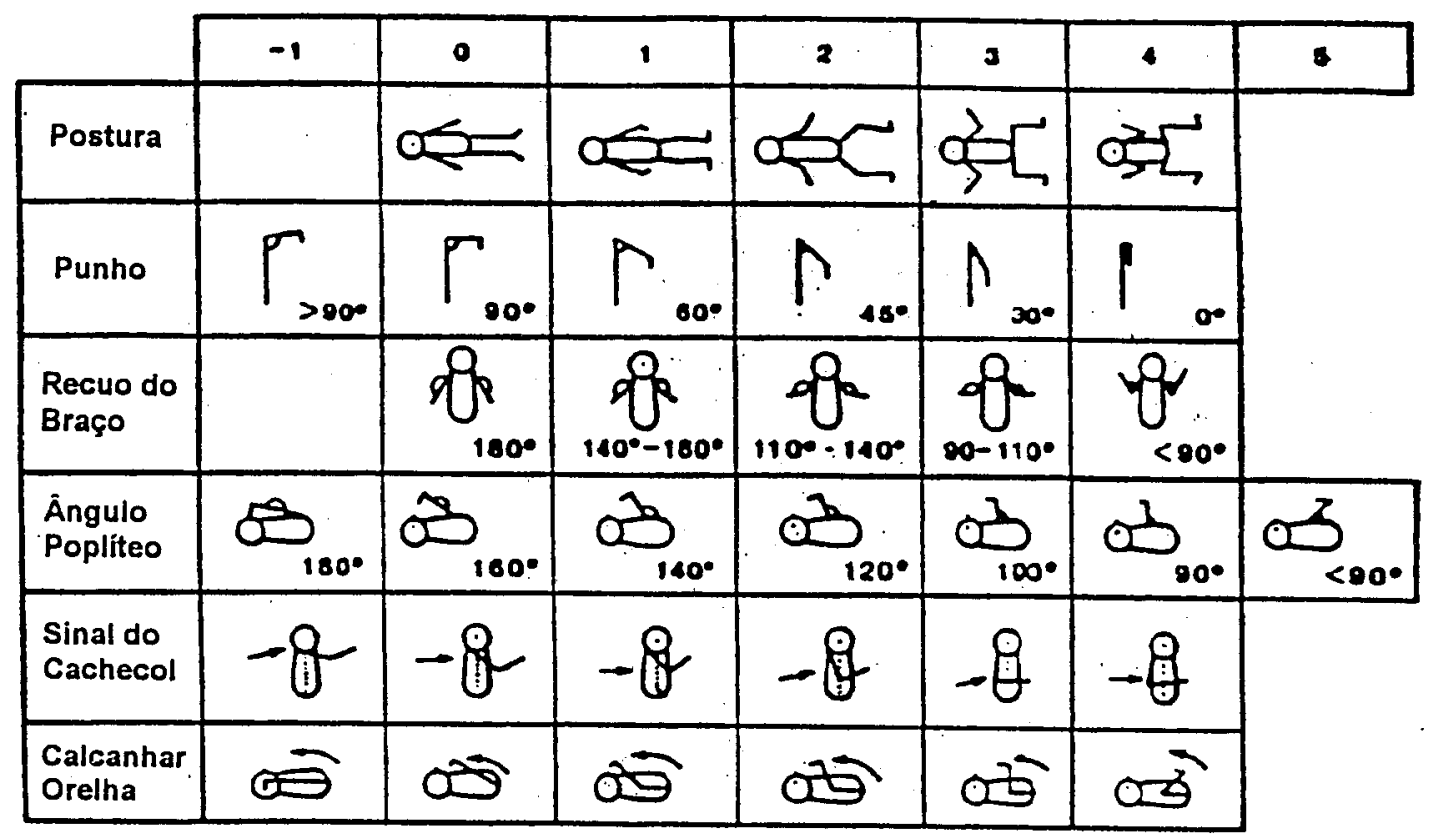

POSTURA: Com o RN quieto e em posição supina

0 - Braços e pernas estendidos

1 - Leve flexão do quadril e joelhos; braços estendidos

2 - forte flexão das pernas; braços estendidos

3 - Braços levemente fletidos; pernas fletidas e abduzidas

4 - Flexão completa dos braços e pernas

PUNHO: Fletir a mão sobre o antebraço com o polegar e 0 indicador do examinador, obtendo-se a flexão máxima. Mede-se o ângulo formado entre o antebraço e a região hipotenar da mão.

RECUO DO BRAÇO: Com o RN na posição supina, fletir os antebraços por 5 segundos, estendê-los completamente puxando-os com a mão e a seguir soltá-los.

ÂNGULO POPLÍTEO: Com o RN na posição supina e com a pelve fixa no colchão, segurar a coxa sobre o tórax e fixar o joelho com o polegar e o indicador. esquerdo. A seguir, extender a perna com o indicador direito no tornozelo e medir o ângulo poplíteo.

SINAL DO CACHECOL: Com o RN na posição supina, pegue a mão da criança e tente colocá-la ao redor do pescoço, o máximo possível em direção ao ombro oposto.

CALCANHAR-ORELHA: Com o RN na posição supina, puxe o pé da criança o mais próximo possível da cabeça, sem forçar. Observe a diastância entre o pé e a cabeça, assim com o ângulo de extensão do joelho. $O$ joelho deve estar solto e ao lado do abdome.

\begin{tabular}{|l|ll|}
\hline Score & \multicolumn{2}{|l|}{ Sem. } \\
\hline-10 & 20 & \\
\hline-9 & 20 & $3 / 7$ \\
\hline-8 & 20 & $6 / 7$ \\
\hline-7 & 21 & $1 / 7$ \\
\hline-6 & 21 & $4 / 7$ \\
\hline-5 & 22 & \\
\hline-4 & 22 & $3 / 7$ \\
\hline-3 & 22 & $6 / 7$ \\
\hline-2 & 23 & $1 / 7$ \\
\hline-1 & 23 & $4 / 7$ \\
\hline 0 & 24 & \\
\hline 1 & 24 & $3 / 7$ \\
\hline 2 & 24 & $6 / 7$ \\
\hline 3 & 25 & $1 / 7$ \\
\hline 4 & 25 & $4 / 7$ \\
\hline 5 & 26 & \\
\hline 6 & 26 & $3 / 7$ \\
\hline 7 & 26 & $6 / 7$ \\
\hline 8 & 27 & $1 / 7$ \\
\hline 9 & 27 & $4 / 7$ \\
\hline 10 & 28 & \\
\hline 11 & 28 & $3 / 7$ \\
\hline 12 & 28 & $6 / 7$ \\
\hline 13 & 29 & $1 / 7$ \\
\hline 14 & 29 & $4 / 7$ \\
\hline 15 & 30 & \\
\hline 16 & 30 & $3 / 7$ \\
\hline 17 & 30 & $6 / 7$ \\
\hline 18 & 31 & $1 / 7$ \\
\hline 19 & 31 & $4 / 7$ \\
\hline 20 & 32 & \\
\hline & & \\
\hline & & \\
\hline & & \\
\hline & & \\
\hline
\end{tabular}

\begin{tabular}{|l|ll|}
\hline Score & \multicolumn{2}{|c|}{ Sem. } \\
\hline 21 & 32 & $3 / 7$ \\
\hline 22 & 32 & $6 / 7$ \\
\hline 23 & 33 & $1 / 7$ \\
\hline 24 & 33 & $4 / 7$ \\
\hline 25 & 34 & \\
\hline 26 & 34 & $3 / 7$ \\
\hline 27 & 34 & $6 / 7$ \\
\hline 28 & 35 & $1 / 7$ \\
\hline 29 & 35 & $4 / 7$ \\
\hline 30 & 36 & \\
\hline 31 & 36 & $3 / 7$ \\
\hline 32 & 36 & $6 / 7$ \\
\hline 33 & 37 & $1 / 7$ \\
\hline 34 & 37 & $4 / 7$ \\
\hline 35 & 38 & \\
\hline 36 & 38 & $3 / 7$ \\
\hline 37 & 38 & $6 / 7$ \\
\hline 38 & 39 & $1 / 7$ \\
\hline 39 & 39 & $4 / 7$ \\
\hline 40 & 40 & \\
\hline 41 & 40 & $3 / 7$ \\
\hline 42 & 40 & $6 / 7$ \\
\hline 43 & 41 & $1 / 7$ \\
\hline 44 & 41 & $4 / 7$ \\
\hline 45 & 42 & \\
\hline 46 & 42 & $3 / 7$ \\
\hline 47 & 42 & $6 / 7$ \\
\hline 48 & 43 & $1 / 7$ \\
\hline 49 & 43 & $4 / 7$ \\
\hline 50 & 44 & \\
\hline & & \\
\hline
\end{tabular}

